\title{
The REDD+ Readiness Stage in Myanmar: Stakeholder Perspectives in Bago Region and Shan State
}

\author{
Thi Thi Han
}

Thesis

DEVELOPMENT STUDIES 592

A 120 point thesis submitted to Victoria University of Wellington in partial fulfilment of the requirements for the degree of Master of Development Studies

School of Geography, Environment and Earth Sciences

Victoria University of Wellington

New Zealand

March 2018 





\section{Abstract}

\section{The REDD+ Readiness Stage in Myanmar: Stakeholder Perspectives in Bago Region and Shan State}

REDD + (Reducing Emissions from Deforestation and Forest Degradation) is a UN initiative, originally introduced in 2005 . The initiative seeks to decrease losses to remaining global forests and other carbon stocks by providing financial incentives to various stakeholder groups in developing countries. The initiative has been controversial, with a wide range of different perspectives on the programme and its implications for forest governance and climate change mitigation. Nonetheless, international and local actors are optimistic about REDD + as a means to reduce carbon emissions. The Government of Myanmar introduced the initiative to the country in 2011. Myanmar is currently in the readiness phase of REDD + and, because there are issues surrounding its implication for forest governance, this thesis explores how this phase is playing out in the country. The overarching research objective of this thesis is to explore how Myanmar is approaching the readiness phase of REDD+, and how different stakeholders engage with the readiness activities.

This study adopts a post-structuralist political ecology approach for two reasons. Firstly, it enabled a broad and nuanced exploration of political, social, economic and cultural factors that shape readiness activities, and forest management in Myanmar. As Myanmar is democratising and liberalising its economy, the country's unique political and economic situation provides context on how these factors shape the initial stage of the REDD+ implementation process. Secondly, post-structuralist political ecology examines meaning making and thus sheds light on how individuals perceive the REDD+ initiative in Myanmar.

The findings from 11 semi-structured interviews and participant-observations show that people are optimistic and enthusiastic about REDD + implementation but perceive and understand the initiative differently. There are many challenges to introducing REDD+ in Myanmar. This study highlights some issues including stakeholders' awareness, poor coordination among stakeholders - especially between government agencies - and general issues of transparency. One of the central findings that has pervaded all themes discussed is a lack of transparency in relation to governance arrangements, land tenure, and relationships between stakeholders. If REDD+ is to progress successfully beyond 
the readiness phase in Myanmar, significant changes need to be made by the central government to ensure clear lines of communication and transparency of information.

Key words: REDD+, climate change, readiness, storylines, governance, land tenure, stakeholders, community forest management, Myanmar 


\section{Acknowledgements}

I would like to thank everyone who has been involved in this research: although I cannot mention everyone here, please know that I am truly grateful.

I would like to especially thank to my interviewees who generously gave their time and shared their valuable experiences during the fieldwork. Without your contribution, this thesis would not have been possible. This would also not have been possible without the support of the Forest Research Institute of Myanmar and the UN-REDD Programme Myanmar.

My supervisor, Dr Amanda Thomas, has given me invaluable support, guidance and encouragement to accomplish this thesis. I am wholeheartedly grateful to your trust and optimism about my work. My academic life has become far more meaningful. Thanks to what I learned from you; I will always feel privileged to have had you as my supervisor.

I would like to thank the New Zealand Agency for International Development (NZAID) for giving me an opportunity to study at Victoria University of Wellington.

I am also grateful to Victoria University, my lecturers, professors, and staff who supported my studies, especially to Rohini, who helped me so often.

I would also like to express my thanks to my friends, classmates, flatmates, and colleagues with whom I have shared and discussed so much, both inside and outside of academic life.

My deepest thanks to my father, sisters, brothers and loved ones who gave me strength and were generous of your time whenever I needed it during my studies and in particular during this thesis. Your trust motivated me.

I would like to dedicate this work to Mary, Mike, Karen, Helen, Ross, and Justin. 


\section{Table of Contents}

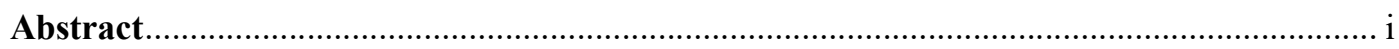

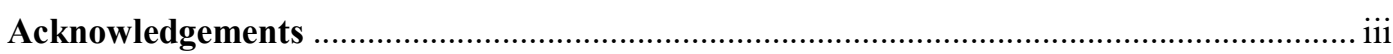

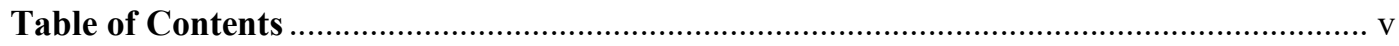

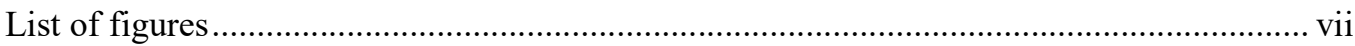

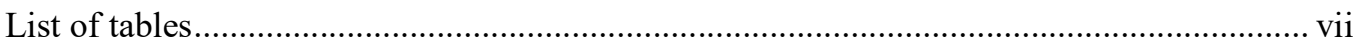

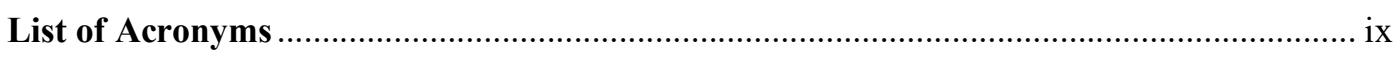

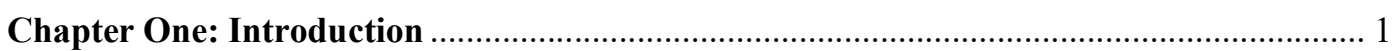

1.1 REDD+ (Reducing Emissions from Deforestation and Forest Degradation Plus) ............. 2

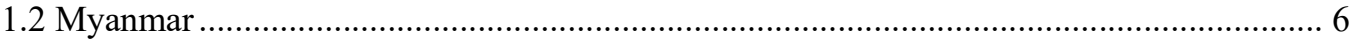

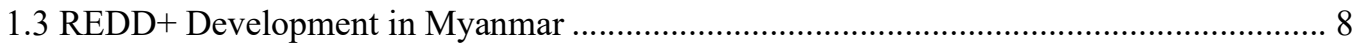

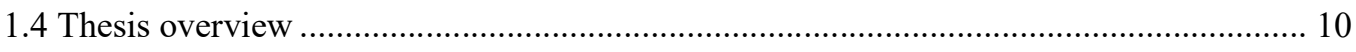

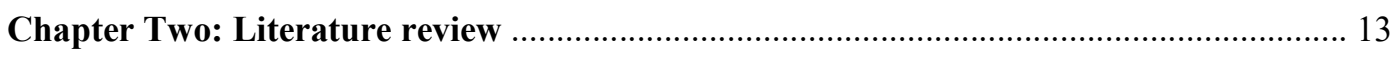

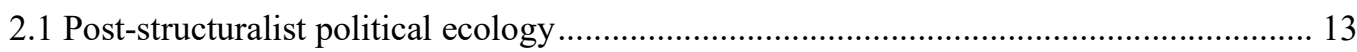

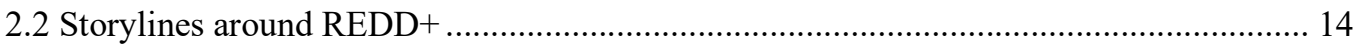

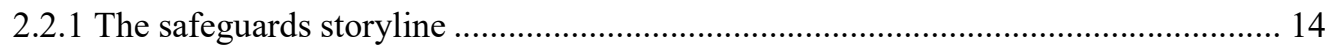

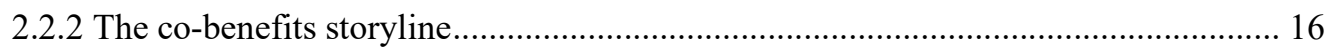

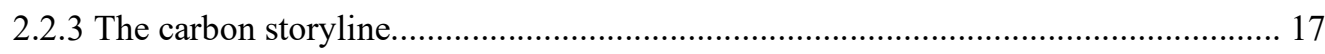

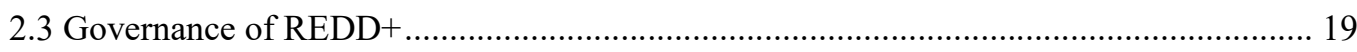

2.3.1 Importance of multi-stakeholder involvement .......................................................... 20

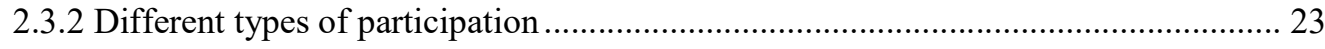

2.3.3 Land tenure and forest-dependent communities ..................................................... 24

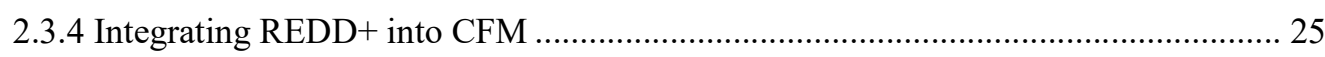

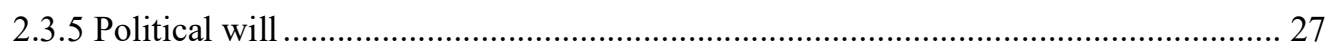

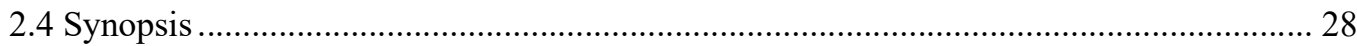

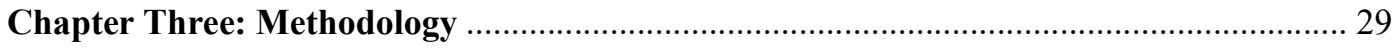

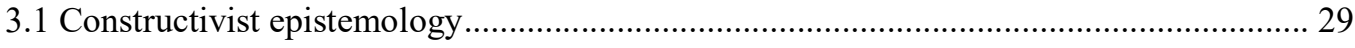

3.1.1 Post-structuralist political ecology and REDD+ in Myanmar ................................. 30

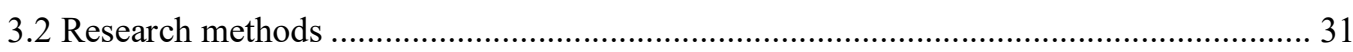

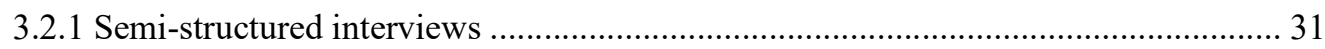

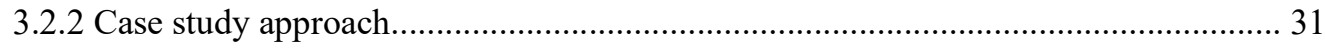

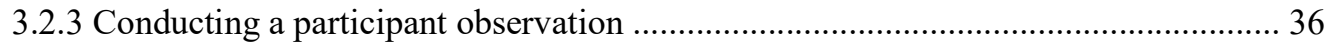

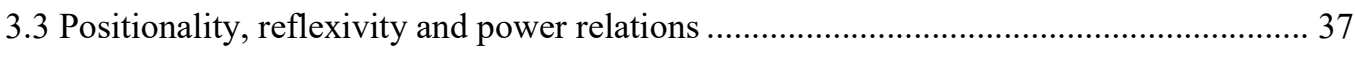

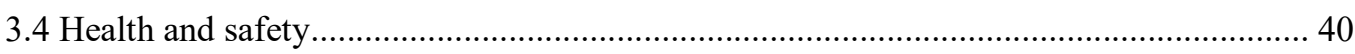

3.5 The project location and the process of recruiting participants ........................................ 40

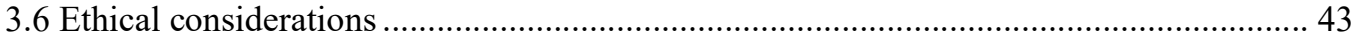

3.7 Data usage, management and analysis ............................................................................. 44 


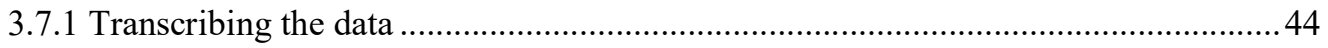

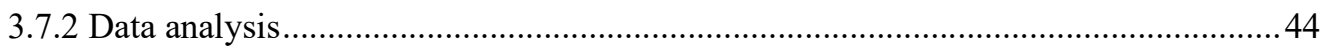

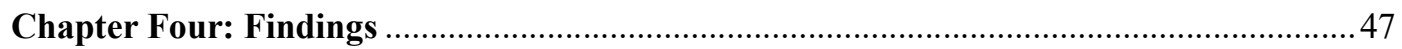

4.1 Motivations to engage with and perceptions of REDD+ implementation.........................47

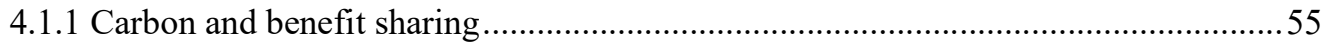

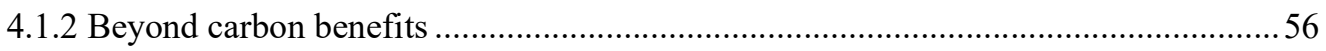

4.1.3 Forest sustainability, forest income and cross-cutting sectors.................................57

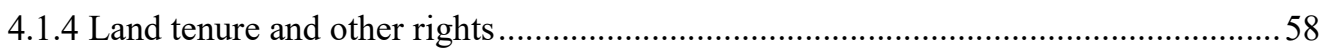

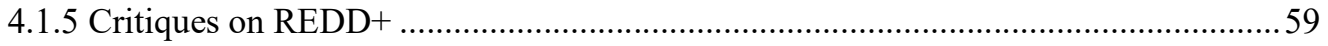

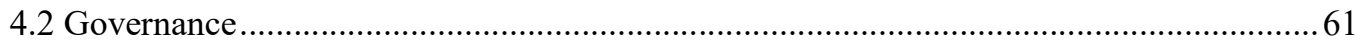

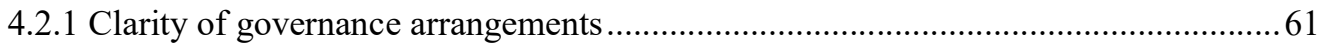

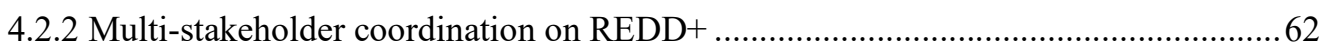

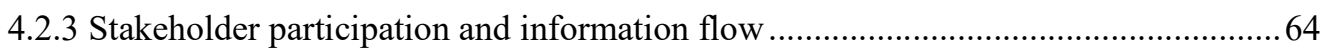

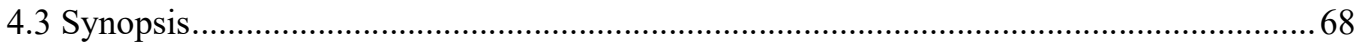

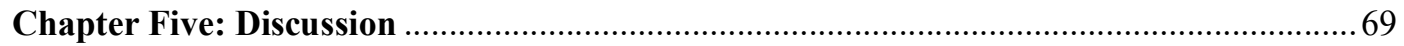

5.1 Storylines around REDD+/ Perception of REDD+ implementation .................................69

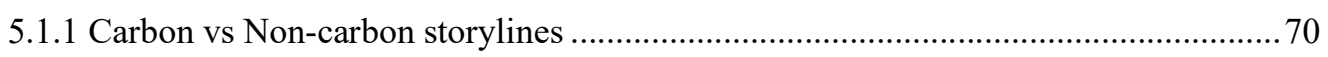

5.1.2 Effective climate change policy (win-win storyline)? ……..................................... 71

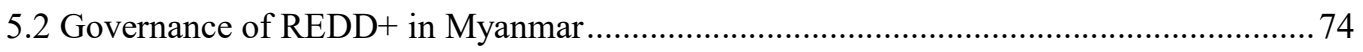

5.2.1 Case study 1: Participant observation in Bago Region................................................ 74

5.2.2 Case study 2: Participant observation in Shan State ...................................................78

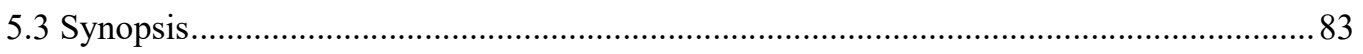

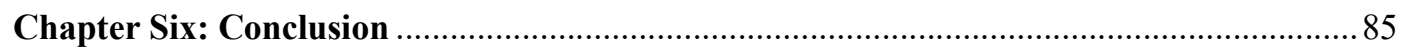

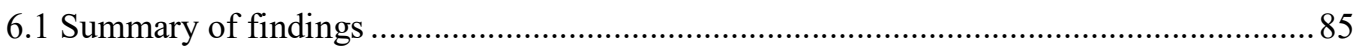

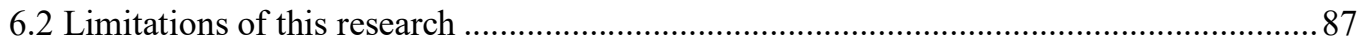

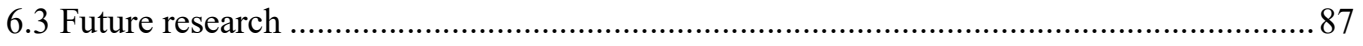

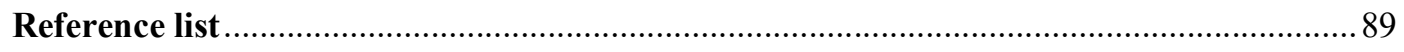

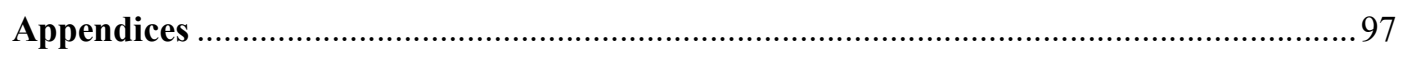

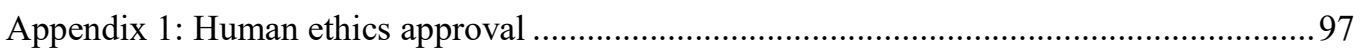

Appendix 2: Interview information sheet......................................................................... 99

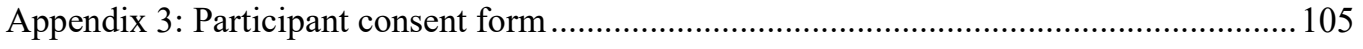

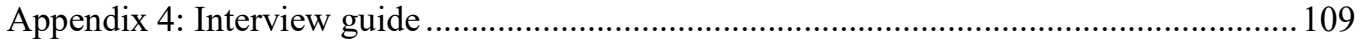




\section{List of figures}

Figure 1.1: Three-Phased Approach to REDD+ under UNFCCC Framework ............................ 5

Figure 1.2: Organizational Structure of Myanmar REDD+ Programme …................................ 10

Figure 3.1: Location Map of Case Study One (Bago Region) .................................................. 34

Figure 3.2: Location Map of Case Study Two (Shan State) ........................................................ 37

List of tables

Table 2.1: Types of Engagement Process (Degree of Participation in REDD+) ……................ 23

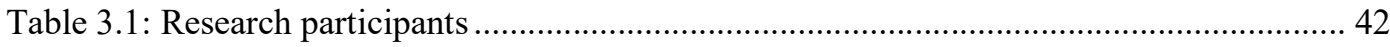

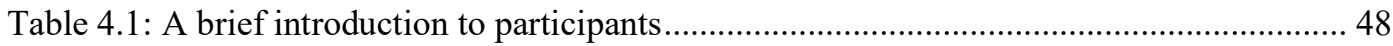




\section{List of Acronyms}

CCF Community-Controlled Forests

CDM Clean Development Mechanism

CECC Central Environmental Conservation and Climate Change Committee

CFM Community Forest Management

COP the Conference of Parties

CSOs Civil Society Organizations

DOM Department of Mines

FAO Food and Agricultural Organization

FD Forest Department

FRI Forest Research Institute

GHG Greenhouse Gases

GOM Government of Myanmar

ICIMOD International Centre for Integrated Mountain Development

IPCC Intergovernmental Panel on Climate Change

KFS Korean Forest Service

MERN Myanmar Environmental Rehabilitation-conservation Network

MOALI Ministry of Agriculture, Livestock and Irrigation

MOECAF Ministry of Environmental Conservation and Forestry

MOEE Ministry of Electricity and Energy

MOHA Ministry of Home Affairs

MONREC Ministry of Natural Resources and Environmental Conservation

NGO Non-Governmental Organization

REDD+ Reducing Emission from Deforestation and Forest Degradation Plus

RECOFTC Regional Community Forestry Training Centre for Asia and the Pacific (The Centre for People and Forests)

TWG Technical Working Group

UN United Nations

UNFCCC United Nations Framework Convention on Climate Change

UN-REDD The United Nations Programme on Reducing Emission from Deforestation and Forest Degradation

WCED World Commission on Environment and Development

WWF World Wildlife Fund 


\section{Chapter One: Introduction}

Forests perform numerous important functions for humans and nature, including the ability to absorb and store carbon dioxide (CO2) from the atmosphere. According to the Millennium Ecosystem Assessment (MEA), forests are essential elements of communities and ecosystems as they provide resources as well as ecological, social, cultural, and spiritual values for many communities (Alcamo, 2003). They cover around 9.88 billion acres, or $31 \%$, of the total land area of the planet (FAO, 2010). However, World Wildlife Fund estimates that approximately 18.7 million acres of forests are lost each year (WWF, 2017). Not only does deforestation and forest degradation have implications for global biodiversity, but they are some of the main contributors to climate change (McDermott, Coad, Helfgott, \& Schroeder, 2012; Singh, 2008). Forest loss from deforestation and degradation, and changes in land-use has generated approximately $20 \%$ of global greenhouse gas (GHG) emissions during the last decade (Corbera \& Schroeder, 2011; McDermott et al., 2012; Singh, 2008).

Parties to the United Nations Framework Convention on Climate Change (UNFCCC) initiated the REDD+ (Reducing Emissions from Deforestation and Forest Degradation Plus) programme in 2005 as a forest-based mechanism to reduce the effects of climate change in developing countries and provide guidance on how these countries should implement REDD+ (UN-REDD, 2016). The purpose of this voluntary climate change agreement is to encourage developing countries to implement REDD+ through providing financial and technical supports to reduce emissions and to manage their forest sustainably (Parker, Cranford, Roe, \& Manandhar, 2013; Vidal, 2009).

Myanmar is currently in the readiness phase of REDD+ and because there are issues around the governance and implementation of the programme, this thesis explores how this phase is playing out in the country. Drawing on a post-structuralist political ecology approach helps me to identify competing individuals' perceptions. I used this approach because it helps me to understand and identify how stakeholders at different levels and scales perceive the REDD+ initiative and how each individual is represented in the programme (West, 2016). Political ecology is a framework that enables analysis of and draws attention to the importance of context to environmental problems. This thesis focuses on the unique context of Myanmar, a country that is democratising and liberalising its economy, but continues to be characterised by poor transparency. 
Therefore, this approach was useful for making sense of the nuanced political, social, economic and cultural factors that shape readiness activities and, more broadly, have shaped forest management in Myanmar. I explored how different stakeholders understand the initiative and how they are represented in different levels in the REDD+ readiness programme. Furthermore, the study examines the governance of REDD + in Myanmar and explores the potential benefits and challenges during the implementation.

The main research question is "How do stakeholders engage with the REDD+ readiness programme in Myanmar?" In order to address this, my specific research questions are as follow:

Sub-questions:

1. How do different stakeholders perceive the REDD+ initiative?

2. How are different stakeholders involved in REDD+ readiness activities?

3. What is the governance structure and how is REDD+ being implemented? Conducting this research is timely and important because the REDD+ readiness stage is crucial to implementing the REDD+ programme in developing countries. As there is no in-depth research conducted about its implementation in Myanmar, it is important to examine power relationships between stakeholders in the early stages of REDD+ implementation. From this research, relevant stakeholders who are involved in the REDD+ programme will better understand how their engagement and their collaboration towards implementing REDD+ are important.

\subsection{REDD+ (Reducing Emissions from Deforestation and Forest Degradation} Plus)

The REDD+ initiative evolved from the idea of "the clean development mechanism" (CDM) which was introduced at the Conference of Parties (COP) to the UNFCCC in Kyoto in 1997. The CDM is a scheme intended to reduce greenhouse gas emissions by allowing emission-reduction projects "by growing trees through afforestation and reforestation" in developing countries to earn certified emission reduction (CER) credits which can be traded and sold to industrialized countries (UNFCCC, 2014; Zomer, Trabucco, Bossio, \& Verchot, 2008, p. 68). Under the Kyoto Protocol, the CDM mechanism became an accounting framework for both developed and developing countries to reduce emissions to meet their emission targets. However the complex 
requirements of $\mathrm{CDM}$ created barriers for developing countries because most

developing countries lack of technical and institutional capacity (Parker et al., 2013) and there were some other contentious issues like whether "avoided deforestation" should be included in carbon credits (Bluffstone, Robinson, \& Guthiga, 2013); under REDD+ avoided deforestation is included. Seymour (2017) argues that this inclusion further helps developing countries to be part of global climate change mitigation.

Initially REDD+ was introduced as RED (Reducing Emission from Deforestation) at COP-11 held in Montreal in 2005 (Corbera \& Schroeder, 2011). But, in 2007, at COP13 held in Bali, forest degradation was included under RED (in addition to the existing deforestation) thus changing the name to REDD. At COP 16 in 2010 the "+" was added because forest conservation, sustainable forest management and the enhancement of forest carbon stocks were added to the initiative. Under the new REDD+, implementing developing countries would receive "results-based payments for verified emissions reductions" when they met UNFCCC REDD+ requirements (UN-REDD, 2016, p. 2).

The UN's vision of REDD+ is that "[d]eveloping countries have significantly reduced their forest and land-based emissions, as a result of incentives from performance-based REDD + mechanisms, while achieving national development goals in a sustainable and equitable manner" (Bluffstone et al., 2013, p. 44; UN-REDD, 2011, p. 6). Stakeholders at both international and national levels are optimistic about REDD+ being able to tackle increasing carbon emissions (Bluffstone et al., 2013). Further, REDD+ is seen as a crucial and cost-effective climate change mitigation instrument because it decreases the cost of reducing emissions and increases forest values (Bluffstone et al., 2013; Bushley \& Khatri, 2011; van der Hoff, Rajão, Leroy, \& Boezeman, 2015). Somorin, Visseren-Hamakers, Arts, Sonwa, and Tiani (2014, p. 87) state REDD+ is "a relatively cheap and promising approach" for climate change mitigation. Some economists agree that slowing forest loss offers "a relatively low cost option for reducing global emissions" (McDermott et al., 2012, p. 64). Stern (2008) also states that REDD+ has been a win-win approach to tackle climate change, to deal with poverty reduction and sustainable forest management, and to provide low cost to reduce carbon emissions. Humphreys (2008) states that REDD+ was created as a global carbon market mechanism aiming to reduce carbon emissions and enhance carbon stocks. Adding to the backers of the scheme, Singh (2008) claims that REDD+ can reduce global carbondioxide emissions through sustainable forest management, carbon stock enhancement, 
and forest conservation. There is widespread optimism about the potential for REDD+ to help mitigate deforestation and forest degradation among other benefits.

The primary mechanism of REDD + is to give financial incentives to developing countries for the protection and better management of their forest resources "by creating and recognizing a financial value for the additional carbon stored" in forest ecosystems (Corbera \& Schroeder, 2011, p. 89). The REDD+ initiative aims to protect threatened forests and wildlife, to provide benefits and development to local communities that depend on the forests (Gebara, 2013; Somorin et al., 2014) and bring prosperity to rural communities (Angelsen, Gierløff, Beltrán, \& den Elzen, 2014). According to UNFCCC, "REDD + must be implemented in the context of sustainable development and reducing poverty" (McDermott et al., 2012, p. 64). The World Commission on Environment and Development (WCED) (1987) broadly defined sustainable development as "a form of economic development that meets the needs of the present without compromising the ability of future generations to meet their own needs".

Existing literature about REDD + shows that its implementation benefits developing countries through donor-financing (Bastakoti \& Davidsen, 2017; Gebara, 2013; Pearse, 2011; Somorin et al., 2014; Vijge, 2015) and selling carbon credits (Bastakoti \& Davidsen, 2017; Bluffstone et al., 2013; Larson et al., 2013). However there is little evidence to support whether the REDD+ mechanism brings co-benefits of poverty reduction to forest-dependent communities in developing countries (Bolin \& Tassa, 2012).

Meanwhile controversy remains about implications of REDD+ in forest governance. (Bushley \& Khatri, 2011). According to Bushley and Khatri (2011), some stakeholders claim that REDD + is an opportunity to enhance forest governance and to promote global conservation while others argue the initiative could destabilise forest governance in some existing governance systems especially when integrating into community controlled forests, like for example in Nepal. There are debates around the programme with a wide range of different perspectives on its implications for forest governance and climate change mitigation (Bushley \& Khatri, 2011; Phelps, Webb, \& Agrawal, 2010). The debates include the criticism that REDD+ is a tool to impose neoliberal policies on developing countries through introducing a capitalist market-based approach to govern forest carbon (Bastakoti \& Davidsen, 2017; Scheba \& Scheba, 2017). 
The UNFCCC recognizes that developing countries need support to lower GHG emissions from land use change and forestry activities. Currently, there are two main multilateral bodies to support developing countries' readiness for REDD+ implementation: the United Nations Collaborative Programme on Reducing Emissions from Deforestation and Forest Degradation in Developing Countries (UN-REDD) and the Forest Carbon Partnership Facility (FCPF) of the World Bank. The UN-REDD Programme is a collaborative body of the United Nations Food and Agriculture Organization (FAO), the United Nations Development Programme (UNDP) and the United Nations Environment Programme (UNEP) (UN-REDD, 2016). In September 2008, the UN-REDD Programme was established to support processes for REDD+ readiness and the development of national REDD+ strategies in developing countries. It aims to assist developing countries in managing their forests by giving incentives and rewards for maintaining the forests (Bluffstone et al., 2013; UN-REDD, 2013).

Moreover, there are various stakeholders such as international and local nongovernmental organizations (INGO/ NGO), governments and private actors involved in REDD+ readiness activities and pilot projects.

There are three phases of REDD+ defined by the UNFCCC: (i) readiness or preparation, (ii) pilot implementation, (iii) and full implementation with reporting and verification of performance, or the phase of performance-based payments (UN-REDD, 2016). In the REDD + readiness phase, countries are required to design action plans and national strategies with relevant stakeholders, to build the capacity to implement it, work on its related policies and measures, calculate forest reference emission levels, address the drivers of deforestation, and design demonstration activities. The pilot implementation phase aims to test the national strategy and action plans designed in phase one, and to provide further capacity building for a full implementation of REDD + . The third (last) phase is to measure emissions reductions and make results-based payments (UN-REDD, 2016, p. 3). Myanmar is in the readiness stage.

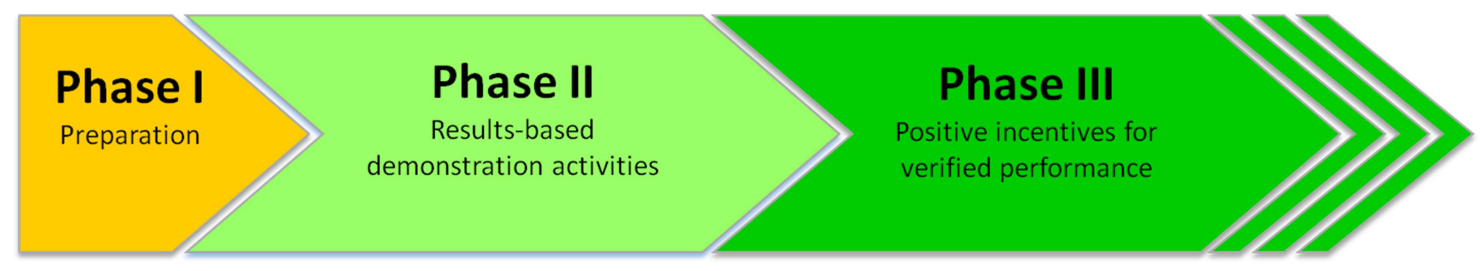

Figure 1.1: Three-Phased Approach to REDD+ under UNFCCC Framework (Source: Myanmar REDD+ Programme (MOECAF, 2014)) 
There are six components to be established under the readiness activities: (i) management of REDD+ readiness, (ii) stakeholder consultation and participation, (iii) development and selection of REDD+ strategies, (iv) implementation framework and safeguards, (v) national forest reference emission level and/ or forest reference level (REL/ RL), and (vi) national forest monitoring system (UN-REDD, 2013, pp. 5-7). The donors and international agencies would ideally work closely with governments and stakeholders in designing the implementation of REDD+ (Bluffstone et al., 2013). Their close collaboration and funding for developing countries are important to prepare for REDD+ implementation as developing countries have raised concerns about inadequate financing and the difficulty in accessing funds in the readiness stage (Parker et al., 2013).

Throughout, this thesis refers to two case studies. These case studies are two REDD+ demonstration sites or pilot projects for the next phase of REDD+ implementation (as explained by the REDD+ national coordinator in Myanmar, 25-July-2017).

Demonstration activities refer to "[a]ctions put in place in a given sub-national region or forest management unit, such as a national park (or a reserved forest), aimed at reducing deforestation or forest degradation in that given locality" (Cadman \& Maraseni, 2012, p. $620)$.

\subsection{Myanmar}

Myanmar has among the highest rates of forest loss per year in the world behind Brazil and Indonesia. Myanmar lost more than 600,000 hectares of forest a year from 2005 to 2015 (MacDicken et al., 2016). The drivers of deforestation and forest degradation are found in both the forestry sector, including illegal logging, and in non-forestry activities such as overharvesting, shifting cultivation, overgrazing, agricultural expansion, mining, and urbanization. Despite these challenges and the political and economic reforms taking place there, the Government of Myanmar (GOM) has committed to reducing deforestation (UN-REDD, 2013). It has been contributing to and involved in REDD+ international negotiation processes since 2011 to conserve the forests and benefit communities who rely on them.

Myanmar has had civil wars or ethnic conflicts since independence from Britain in 1948. The major ethnic group took control of the military and the government and their aim was to bring all populations under their control. Since then, marginalised some 
ethnic minority groups have been fighting for their rights (Holliday, 2010; Jolliffe, 2014). After the 2010 election the new government negotiated a fragile peace process and has given more attention to ethnic and religious conflicts and human rights violations, but recent conflicts with the Rohingya people have drawn international attention.

The government began liberalising the country's economy by prioritising economic development (Jolliffe, 2014). The country opened up for development and aimed for rapid economic growth. Myanmar has moved its economy to a more market-oriented economic system and to more industrialization (GOM, 2012; Htun, 2009) and opened its economy to foreign direct investment (FDI) in the sectors of energy, mining and agriculture (UN-REDD, 2013). Through the transition towards a market economy from a socialist economy, the country has been taking steps towards social, political and economic reforms (GOM, 2012) "to end its isolation and integrate its economy with the global system" (Prakash, 2013, p. 1). As the country is rich in natural resources, the country's economy relies on its primary sectors such as the extraction and exports of natural resources (Htun, 2009).

In terms of sustainable forest management and economic development, Htun (2009) states that forest sustainability efforts are often in conflict with the use of forest resources for income. Similarly, forest sector policies are often inconsistent with those of economic sectors like agriculture or mining. Furthermore, the forestry sector has an annual income target mandated by the government. More often than not, this goal is attained by additional use of forest resources, sometimes even overexploitation (Htun, 2009).

Myanmar's forests are economically and socially significant to the country as more than $70 \%$ of population lives in rural areas and are highly dependent on the forests for their livelihood. Therefore, the role of forest-dependent communities is crucial in forest management in Myanmar. In order to manage forests sustainably and to allow local populations to engage in forest management, the government introduced community

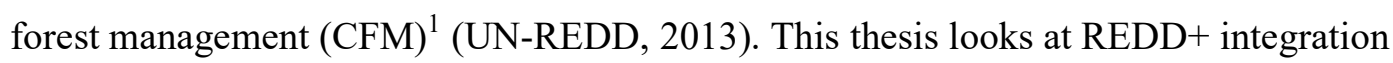
into CFM areas and REDD+ development in Myanmar. Existing literature shows that

\footnotetext{
${ }^{1}$ CFM in Myanmar will be briefly explained in Chapter Two (Literature Review) and there will be a discussion about REDD+ integration into CFM in the country which will be presented in Chapter Five (Discussion).
} 
there are both opportunities and challenges to integrating these two systems and it is crucial to examine the initial stages of their integration. This can help the government and REDD+ related stakeholders to avoid potential challenges.

\subsection{REDD+ Development in Myanmar}

Currently, there is no in-depth research conducted on REDD+ implementation in Myanmar. Research in other countries points to a number of issues coming up around REDD+ implementation, like institutional arrangements and land tenure (Larson et al., 2013). The following section explains why and how Myanmar introduced REDD+. Myanmar ratified the climate change convention (UNFCCC) in November 1994 and signed the Kyoto Protocol in 2003. It became a member country of the UN-REDD Programme in December 2011. A REDD+ Readiness Roadmap was developed in 2013 to start implementing REDD+ readiness activities and to establish the REDD+ mechanism. The vision of the Government of Myanmar (GOM) for REDD+ development is:

to contribute to the achievement of a climate resilient, low carbon and sustainable development path of the country (the Myanmar Climate Change Strategy and Action Plan (MCCSAP) goal) through transformational change in the land use and forestry sector by reducing deforestation and forest degradation while enhancing livelihoods, sustainable growth and development (MONREC \& UN-REDD, 2017, p. 1).

The roadmap was developed by the Government of Myanmar (GOM) with the support of the UN-REDD Programme. The Government of Norway and the UN-REDD Programme provided the necessary funding to prepare the roadmap. UN-REDD also helped as it is one of the main technical supporters for implementing REDD + in Myanmar. Technical assistance is crucial in REDD+ implementation because most developing countries do not have the infrastructure and capacity necessary to adequately measure such things as carbon stock, report data, or emissions. As REDD+ is a performance-based mechanism, these structures are crucial for proper implementation (Parker et al., 2013). The roadmap also includes a set of instructions for use during its readiness activities. According to UN-REDD, it is supposed to be regularly reviewed and updated by GOM and UN-REDD during its implementing phase. Based on these findings it is then meant to be aligned to the local context and the UNFCCC's requirements (UN-REDD, 2013). 
Also, according to the structures outlined by UNFCCC, Myanmar has introduced subnational REDD+ pilot projects and demonstration activities. A National REDD+ Strategy is currently being developed through multi-stakeholder consultation at the national level. However, the country is still in an early stage of developing its monitoring, reporting and verification (MRV) system, forest reference levels (FRL), and its REDD+ safeguards system. To develop these systems, the GOM has established a REDD + task force (TF), chaired by the Forest Department (FD) of Ministry of Natural Resources and Environmental Conservation (MONREC) ${ }^{2}$. The task force (TF) manages and coordinates the readiness process. The GOM also established technical working groups (TWGs) ${ }^{3}$ to design and develop the necessary systems which are required to make the REDD+ initiative effective. Other stakeholders and their contributions are noted below.

There are many stakeholders involved in making decisions about REDD+ activities and implementation. These include donor agencies, the private sector, and communities (Corbera \& Schroeder, 2011). According to Somorin et al. (2014), stakeholders in the REDD+ context are state and non-state actors. The figure below shows many of the different groups involved in Myanmar. The core membership of the National Steering Committee/ Programme Executive Board (NSC/ PEB) includes UN-REDD (a collaborative body of UNDP, UNEP and FAO), the Forest Department (FD), civil society organizations (CSOs), indigenous peoples ${ }^{4}$, and other stakeholders such as academics, researchers, local communities, and the private sector (MONREC \& UNREDD, 2017).

\footnotetext{
${ }^{2}$ At that time, it was called MOECAF (Ministry of Environmental Conservation and Forestry). After the new government took power in 2016, MOECAF was integrated with Ministry of Mines (MOM) and it becomes MONREC.

${ }^{3}$ GOM formed six TWGs, among them three TWGs: (i) TWG on Drivers and Strategies, (ii) TWG on Stakeholder Engagement and Safeguards, and (iii) TWG on National Forest Monitoring Systems and Forest Reference Emissions Levels/ Forest Reference Levels are active at the moment. The other three TWGs are TWG on REDD+ Project, Finance and Benefit-sharing, and Legal. (UN-REDD, 2013)

${ }^{4}$ In Myanmar, indigenous peoples refer to ethnic nationalities (UN-REDD, 2013) and there are 135 ethnic nationalities in Myanmar according to a 1982 nationality law (Holliday, 2010).
} 


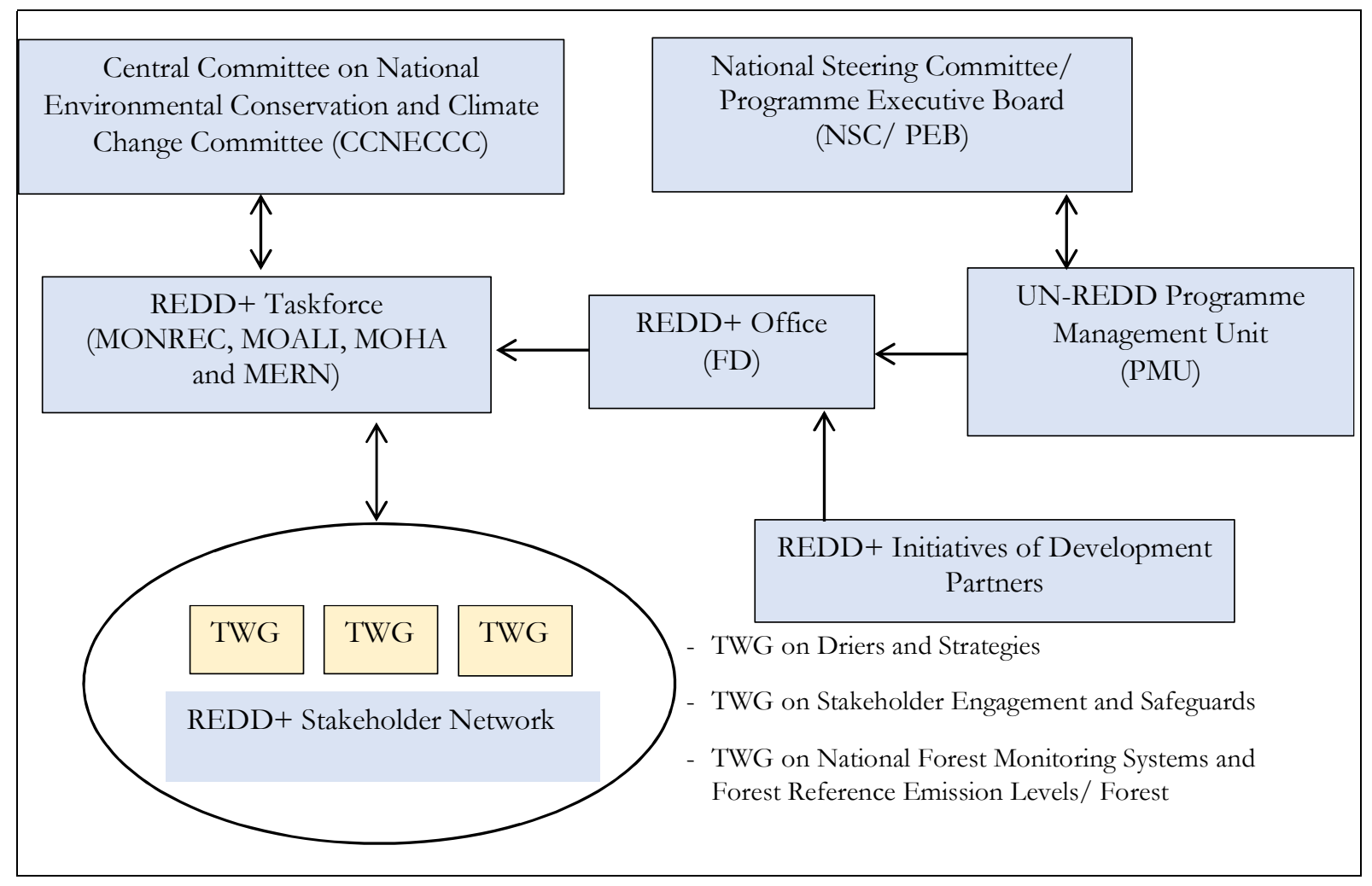

Figure 1.2: Organizational Structure of Myanmar REDD+ Programme

(Source: Myanmar REDD+ National Programme, Forest Research Institute, Forest Department, MONREC)

Different stakeholders or actors involved in the REDD+ initiative have different views, understandings and visions of REDD + . Relative to other actors, the private sector in REDD+ implementing countries shows the least interest and involvement in the REDD+ process, like for example in Cameroon (Somorin et al., 2014). In most REDD+ developing countries, governments are in a unique position to lead the negotiation and coordination among stakeholders at both the global and the local levels. In Myanmar, this coordination is proving to be difficult. There are still uncertainties around how REDD+ will function on the ground and how the people living in the forests will be affected and or involved in REDD+. More involvement of local governments could help the national government coordinate between stakeholders.

\subsection{Thesis overview}

As Myanmar is in the readiness phase of implementation, and moving into the next stage(s), this research aims to better understand how REDD+ is perceived by the various stakeholders involved. The next chapter (Chapter Two) presents existing 
literature around REDD+. Chapter Three discusses the methodology I used to address the objective and research questions. I highlight my findings from my fieldwork in Chapter Four. Chapter Five discusses the findings in relation to the existing literature. Finally, the concluding chapter (Chapter Six) sets out the contribution of this study to existing research, offers some recommendations for future REDD+ readiness activities, as well as explains the research limitations with some recommendations for further research. 


\section{Chapter Two: Literature review}

This chapter reviews literature that takes a critical approach to REDD + . It focuses on research that has examined different stakeholders and their roles in the scheme, particularly in REDD+ readiness activities, as well as governance arrangements and successes and failures of REDD+ so far. First, the chapter explains the overarching body of literature that frames this research, post-structuralist political ecology. Then it explores some of the storylines and discourses that centre around REDD+, and some issues that have emerged in the implementation of REDD + . Following this is a discussion of literature examining how REDD+ related stakeholders and institutions are involved in REDD+ initiatives and how they coordinate amongst themselves and with other stakeholders. Particular attention is given to literature exploring the potential of integration REDD+ into community forest management (CFM).

\subsection{Post-structuralist political ecology}

Political ecology is an approach which helps to understand the complex relations between society and nature (Watts, 2000). It focuses on the relationships between politics, economics and society in environmental changes and management. According to West (2016), political ecology arose because there had been an inequality and a power imbalance among different actors, such as state authorities and communities, concerned with the use and management of natural resources, and environmental change. Political ecology is interested in looking at who is vulnerable to, and who benefits from environmental changes (West, 2016). Post-structuralist political ecology aims to identify different discourses and tries to understand how different discourses and ideas compete. According to Foucault, discourse is "[a] group of statements which provide a language for talking about - a way of representing the knowledge about - a particular topic at a particular historical moment" and meanings come from within discourse (Hall, 2001, p. 72). Further, Hajer and Versteeg (2005) define discourse as "[a]n assemble of ideas, concepts, and categories through which meaning is given to social and physical phenomena, and which is produced and reproduced through [...] practices" (Hajer \& Versteeg, 2005, p. 175). Post-structuralist political ecology looks at how individual persons, institutions or communities see and interpret the natural environment, and how they interact differently with their environment (West, 2016). Therefore, post-structuralist political ecology enables an analysis of how different 
stakeholders understand and construct their environment (nature), how they perceive the REDD+ initiative in Myanmar and how they engage with REDD+ readiness activities.

\subsection{Storylines around REDD+}

Beyond the general positive portrayals of REDD+, there are different 'storylines' for understanding the REDD+ mechanism. Vijge (2015) conceptualises three storylines about this: a safeguards storyline, a co-benefits storyline, and a carbon storyline. She adopted these storylines from scholarly and political debates and applied them to understand the first REDD+ project in India. The storylines Vijge highlighted are useful for understanding the competing agendas and perspectives of REDD + . They are discussed below.

\subsubsection{The safeguards storyline}

At COP-16 in 2010, UNFCCC adapted the Cancun Agreements which require REDD+ implementing countries to promote and support seven safeguards to prevent negative impacts on the environment and local communities. According to parties to the UNFCCC, safeguards related to REDD+ aim to prevent and reduce harm to biodiversity and people. They also prioritise the rights of individuals potentially affected by REDD+ activities. This is also known as a 'rights-based approach' (the_REDD_desk, n.d.). In contrast, the World Bank defined 'safeguards' as "a term that ... refers to measures to prevent and mitigate undue harm from investment or development activities" (World Bank (2005) in McDermott et al., 2012, p. 64; the_REDD_desk, n.d.). This is sometimes known as a 'risk-based approach'.

Concerning safeguards requirements, REDD+ actors at all levels show an interest in including safeguards that carefully consider the rights of forest-dependent communities and biodiversity conservation throughout the implementation of REDD+ activities (Bastakoti \& Davidsen, 2017; McDermott et al., 2012; van der Hoff et al., 2015). Nevertheless, McDermott and colleagues (2012) argue that donor agencies, development partners and investors are more interested and involved in carbon benefits or carbon values (carbon trade) and risk mitigation, while NGO actors emphasize social and environmental benefits and rights or non-carbon values. Rowe (2015) states that there are multiple interests among actors and there is no specific actor who dominates others within the REDD+ context. There are different perceptions about the programme and how the power is distributed among different levels of REDD+ governance and 
there is a clear connection between power relations and discourses surrounding REDD+ (Bastakoti \& Davidsen, 2017; Rowe, 2015). Rowe (2015) explains that the US stood as a leader for defining REDD+ in the early days of its introduction, focused on technical issues, and prioritised carbon benefits, but this was criticized by developing countries, NGOs and the forestry communities who preferred non-carbon benefits. International policy then shifted from only focusing on carbon benefits to also considering other factors, including the idea of safeguards and non-carbon benefits.

McDermott and colleagues (2012) argue that the concepts of additionality and equity arise when we consider 'safeguards'. According to McDermott et al. (2012), the idea of additionality is to address the need for measurable net social benefit, while equity focuses on the distribution of costs and benefits among different stakeholders at all levels. Similar to Vijge's explanation, McDermott and colleagues (2012) argue that safeguards in REDD+ are for non-carbon forest values (i.e. biodiversity conservation; security of land tenure and social equity). In Nepal, some in civil society actors perceive safeguards as an essential element to include in REDD+ activities. They argue that the REDD+ mechanism is unlikely to succeed without consideration of safeguards to promote livelihood opportunities for forest-dependent communities and consideration of environmental issues. McDermott et al. (2012) argue for a safeguards storyline because there are potential risks and challenges in REDD+ implementation such as governance, land tenure, resource rights, high incidents of corruption and the capacity to institutionalize the REDD+ mechanism in developing countries. According to Vijge's study, this safeguards storyline is prominent among REDD+ scholars and practitioners (Vijge, 2015).

Although the core objectives of REDD+ are carbon trading and providing incentives for developing countries to conserve forests, consideration of safeguards emerges as a discourse among some REDD+ actors to prevent environmental and social risks (Bastakoti \& Davidsen, 2017; Vijge, 2015). The REDD+ stakeholders who argue for the need for safeguards recognize both economic growth and forest management as well as the social, cultural and environmental values. Vijge (2015) highlights that the safeguards storyline accounts for carbon benefits but safeguards should prevent any negative impacts on non-carbon values such as environmental and social benefits for forest-dependent communities. 


\subsubsection{The co-benefits storyline}

The co-benefits storyline focuses on both carbon and non-carbon benefits. This storyline is seen as a win-win situation as it brings economic growth through carbon credits, mitigates climate change and also conserves the natural environment (Chhatre et al., 2012; McDermott, Levin, \& Cashore, 2011; Phelps, Friess, \& Webb, 2012; Stern, 2008). According to Vijge (2015), the safeguards storyline can support the co-benefits storyline: when safeguards are emphasized in the REDD+ programme, it will lead to cobenefits for the nations and communities. Some actors such as conservation organizations, donor agencies and governments view "REDD+ as a win-win solution for climate change mitigation, poverty reduction, and conservation" (Bastakoti \& Davidsen, 2017, p. 10; Pearse, 2011) which is similar to what Vijge (2015) highlights. Similarly, another storyline proposed by Bastakoti and Davidsen (2017) explains that some stakeholders believe there is a need to look beyond carbon and non-carbon benefits to determine the success or failure of REDD+. Bastakoti and Davidsen (2017) highlight safeguards as a means to minimize social and environmental risks as well as to secure livelihoods of local communities and to promote biodiversity conservation. They further argue that REDD+ is unlikely to succeed unless the scheme considers the interests of local communities while ensuring that its activities provide opportunities to improve local communities' livelihoods (Bastakoti \& Davidsen, 2017).

Developing countries have embraced the REDD+ promises of sustainable development and a cost effective 'win-win-win' solution in ecological, economic and social terms to mitigate climate change issues (Stern, 2008; van der Hoff et al., 2015). This has been the case in Brazil (van der Hoff et al., 2015), and in both Cameroon and Indonesia, the governments were interested in REDD+ because of the possibility of multiple benefits. For the Government of Cameroon, REDD+ was perceived as a solution to mitigate the country's deforestation rate; the government was interested in REDD+ to promote sustainable forest management by slowing deforestation and increasing social and economic benefits (Somorin et al., 2014). The Cameroon Government also believed that REDD+ could support the establishment of a forest governance policy (Somorin et al., 2014). According to McDermott et al. (2012), a forest governance structure helps by establishing which roles each entity plays and what level of participation they should have in forest management. 
Improving forest governance through the REDD+ initiative also attracted Indonesia (Astuti \& McGregor, 2015). The Indonesian Government aimed to achieve financial rewards through reducing carbon emissions from land use change and through carbon trading under the REDD+ performance-based mechanism (Astuti \& McGregor, 2015). However, a study in Indonesia found that some forest stakeholders were against carbon trading, other actors remained unclear about whether REDD+ had any impact on Indonesia's forest governance and some NGOs were concerned about the social and environmental impacts from carbonization (Astuti \& McGregor, 2015). The concepts of safeguards and non-carbon benefits are dominant around civil society organizations and indigenous communities (Vijge, 2015). This underscores the appeal of the co-benefits storyline.

\subsubsection{The carbon storyline}

The carbon storyline aligns with the primary focus of the REDD+ initiative to mitigate climate change by storing and enhancing carbon stocks in forests. Non-carbon values or safeguards are unlikely to be considered in this storyline. Therefore, a storyline of carbon surrogacy has emerged across REDD+ stakeholders who perceive it as a new form of colonization (Bastakoti \& Davidsen, 2017; Okoh, 2015). This storyline argues that REDD+ does not help to reduce carbon emissions and states that Global North is transferring the burden of carbon emissions to Global South. According to these critiques of REDD+, the scheme provides a mechanism by which developing countries are burdened with reducing carbon emissions while Global North or developed countries continue their emissions (Bastakoti \& Davidsen, 2017). Therefore some actors such as civil society organizations, especially from indigenous or local communities that depend on forests for their livelihoods, view REDD+ as a North-South divider (Allan \& Dauvergne, 2013; Bastakoti \& Davidsen, 2017; Cadman \& Maraseni, 2012). They are also concerned about Global North's dominance in forest governance under REDD+ implementation (Bastakoti \& Davidsen, 2017).

Van der Hoff et al. (2015) argue that REDD+ is an efficient mechanism to reduce carbon emissions and to create financial rewards through carbon stock in Brazil. There, the private sector emphasizes the carbon market, but so do other stakeholders like some government agencies, environmental NGOs, and indigenous communities, who support the carbon commodification discourse because they receive funding for local 
development. However, some stakeholders are concerned about carbon commodification and carbon markets, a fair distribution of both financial and nonfinancial benefits, the development of a monitoring, reporting and verification (MRV) system, and designing and developing safeguards (van der Hoff et al., 2015). These challenges are similar to the experiences of other developing countries. Astuti and McGregor (2015) found that some activists in Indonesia see REDD+ as a false solution to tackle the global climate change issues through a neoliberal idea of carbonization.

The carbon commodification storyline can be characterised as neoliberal because this storyline argues that the REDD+ scheme commodifies forest carbons and encourages a capitalist market-based approach to govern forest carbon and to enhance carbon stock (Bastakoti \& Davidsen, 2017; Scheba \& Scheba, 2017). Scheba and Scheba (2017) see neoliberal conservation as a way to force developing countries to commodify their natural resources. Van der Hoff and colleagues (2015) state that the carbon commodification storyline about REDD+ encourages neoliberal conservation through a voluntary market; but despite the voluntary nature of developing countries' engagement, they argue that neoliberal principles, derived from capitalism, could promote a type of neo-colonization (van der Hoff et al., 2015). Therefore some indigenous peoples are critical of REDD+ believing that it might lead people to depend on payment from the programme (Erazo, 2016). Erazo (2016) further highlights that developing countries implement the policies and programmes that the international community wants; developing countries must decide whether or not they want to participate in any particular programme in the future in order to avoid dependency on the international community.

Many of these storylines can be grounded through case studies in Nepal, the location of several rich studies of REDD+. Bastakoti and Davidsen (2017) found that at the start of the implementation stage, all the actors involved in the REDD+ process anticipated that REDD+ would provide a win-win opportunity as they believed that it would bring economic benefits through financing and selling carbon credits, and providing opportunities for local communities who depend on the forest for their livelihoods. Bluffstone et al. (2013) highlight that REDD+ provides payments for environmental services (PESs) but Evans, Gruba, and Zobel (2014) argue that REDD+ is a fund-based mechanism which is more like foreign aid than a true PES scheme. Bushley and Khatri (2011) found that the Nepal Government was most interested in receiving funding from 
foreign donors through the REDD+ scheme because they wanted to establish a 'carbon trust fund' from the funding they received to build capacity in its forestry sector.

According to Bastakoti and Davidsen (2017), however, some of the actors realized that REDD+ was not addressing biodiversity conservation or social benefits; therefore their perspectives on its value shifted and they no longer saw the initiative as a win-win. The Nepal Government's centralisation of forest governance through REDD+ restricted the involvement of civil society organizations and communities and expanded the role of international actors. Technical challenges related to measuring forest carbon further limited the autonomy of local communities (Bastakoti \& Davidsen, 2017). The result was that the benefit-sharing mechanism became unclear and some of the actors, such as indigenous peoples or local communities, did not receive the financial benefits they were entitled to (Gebara, 2013; Pearse, 2011). Therefore even though actors like policy makers and economists still saw REDD+ as a win-win, local communities started seeing the initiative as a tool to limit their control in community forestry (Bastakoti \& Davidsen, 2017; Pearse, 2011). The presence of many storylines in one case study demonstrates how these storylines can exist simultaneously and compete, with differing effects for different actors, as REDD+ is implemented.

\subsection{Governance of REDD+}

Governance of a REDD+ project is a complex process with many variables and many storylines. According to McDermott et al. (2012) and Cadman and Maraseni (2012), a forest governance system looks at (i) governance structure (institutional arrangements) which explains which actors are involved and their level of participation; and (ii) the process of implementing the programme. Cadman and Maraseni (2012) argue that the success of REDD+ depends on governance arrangements that can deliver reduced carbon emissions as well as being inclusive and transparent. This section focuses on issues and challenges around REDD+ implementation concerned with stakeholders' involvement in the REDD+ programme and land tenure issues. It also reviews the literature around the importance of local communities in REDD+ and how integrating REDD+ into the community forest management (CFM) system can affect forest users.

The literature shows that REDD+ implementation benefits developing countries through donor-financing and selling carbon credits, and it can also bring opportunities and values to developing countries' forests (Bluffstone et al., 2013; Larson et al., 2013; 
Poudel, Thwaites, Race, \& Dahal, 2014). Sunderlin et al. (2014) state that REDD+ supports people to address land tenure issues. However there are still issues around the REDD+ initiative such as the livelihood of local and indigenous communities, insecurities related to land and forest tenure (Bluffstone et al., 2013; Larson et al., 2013; W Sunderlin et al., 2014) as well as governments' unwillingness to decentralise forest management (Bluffstone et al., 2013). Some scholars highlight that there are forest governance issues related to stakeholder participation (Newton et al., 2015), power inequalities among stakeholders in the process of decision-making and designing benefit-sharing mechanisms, (Atela, Quinn, Minang, Duguma, \& Houdet, 2016; Bushley \& Khatri, 2011; Gebara, 2013; Ojha, Khatri, Shrestha, Bushley, \& Sharma, 2013) and land ownership (Larson et al., 2013; Leggett \& Lovell, 2012). Therefore, the UNFCCC has carefully considered how to institutionalize REDD + in local contexts in terms of designing national strategies, implementing policies, and developing capacity building (McDermott et al., 2012).

\subsubsection{Importance of multi-stakeholder involvement}

There are many approaches to looking at how different stakeholders and institutions engage with REDD+ implementation and how they interact with each other. The interactions between different stakeholders and institutions, and their involvements are crucial in REDD+ implementation, especially in the REDD+ readiness stage (Atela et al., 2016; Bushley \& Khatri, 2011; Corbera \& Schroeder, 2011). However, literature shows that some stakeholders find limitations in engaging with the REDD+ process (Astuti \& McGregor, 2016; Atela et al., 2016; Bushley \& Khatri, 2011; Gebara, 2013; Newton et al., 2015).

Multi-stakeholder involvement in REDD+ is vital for its effective implementation (Atela et al., 2016; Bluffstone et al., 2013; Ojha et al., 2013). Atela et al. (2016) and Bluffstone et al. (2013) explain all the stakeholders related to REDD+ implementation should work closely and carefully to design REDD+ policy. During one study of the Kenyan REDD+ project, Atela and colleagues (2016) suggested that strong multistakeholder consultation and engagement with the REDD+ scheme could support effective REDD+ implementation. Similarly, Leggett and Lovell (2012) recommended that the Government of Papua New Guinea (PNG) conduct comprehensive community 
consultations at the early stage of REDD + development to ensure free, prior, informed consent (FPIC) is given to landowners and communities.

The forest-dependent community is one of the most important stakeholders in the REDD+ initiative (Atela et al., 2016; Gebara, 2013; Leggett \& Lovell, 2012). Bluffstone et al. (2013) highlight that households in most low-income countries are dependent on forests to provide needs such as wood for fuel and building materials for their daily lives. However, the implementation of REDD+ requires that deforestation and forest degradation are reduced, and forests conserved. In terms of forest management, Newton and colleagues (2015) argue that REDD+ can fund these communities to expand forest management areas and can provide opportunities for the extraction of forest resources in a sustainable way. Therefore while the local communities are impacted, they also play an important implementation role in REDD+. Some scholars state that forest management systems cannot be effective without their participation (Gebara, 2013; Hlaing \& Inoue, 2013; Newton et al., 2015). Moreover the REDD+ initiative will only work when local communities' rights and needs are addressed and respected (the_REDD_desk, 2016). However, there are some limitations and challenges to local participation in forest management (Newton et al., 2015). Phelps et al. (2010) raise a concern about how the rights of local communities and indigenous peoples will be protected in the context of REDD+; they highlight the rights of local communities to share financial benefits, to be included in the decision-making process in the programme, and to have their knowledge on forestry resources respected.

Atela et al. (2016) argue that even though acknowledging the roles and providing for the representation of different stakeholders is very important for successful implementation, this acknowledgement is not always present. Bushley and Khatri (2011) found that there are power inequalities among stakeholders. They, amongst many in the literature, have found that central governments, donor agencies and technical consultants are key actors who hold power and dominate in designing the policies for REDD+ and in the decisionmaking process in REDD+ implementation. These key stakeholders are more powerful than other actors whose voices are not heard enough (Bushley \& Khatri, 2011; Ojha et al., 2013). The literature shows that there is limited or poor participation of some stakeholders, such as local communities and the private sector, in the REDD+ process, particularly in the decision-making process even when REDD+ systems are being implemented at the local level (Atela et al., 2016; Bushley \& Khatri, 2011; Ojha et al., 
2013). Ojha and colleagues (2013) also highlight that external actors, such as donors and international organizations, drive Nepal's REDD+ process and restrict the voices of local communities as technical REDD+ terms and knowledge are developed outside the local communities.

Leggett and Lovell (2012) also find that there is an uneven power balance between a group of elites who would like to gain benefits from REDD+ and some land owners and local communities in PNG. There is a lack of comprehensive consultation with local communities and land owners and the scale, importance, and impact of traditional cultivation practices are underestimated. Their study highlights a critical situation of carbon tenure and they argue that if these conditions continue, future REDD+ projects are unlikely to succeed (Leggett \& Lovell, 2012).

One study in Nepal and Tanzania by Newton et al. (2015) points out the crucial role of local community involvement in REDD+ implementation. The study states that higher community participation is the key for implementing REDD+ effectively. However, there are some limitations for local communities' involvement such as the need for technical knowledge to be able to monitor, report, and verify the carbon stock (Newton et al., 2015). A study in Kenya found there is limited or no representation of the local communities and forest-dependent communities in the national taskforce although these actors are important stakeholders in REDD+ development (Atela et al., 2016). Moreover, they found that there is a lack of adequate consultation and engagement with other key sectors outside the forestry sector such as the agricultural sector. Therefore Atela and colleagues argue that a strong stakeholder engagement or a full active participation of different stakeholders is required for an effective implementation of the REDD+ initiative (Atela et al., 2016). 


\subsubsection{Different types of participation}

As shown in the table below, there are different levels of participation in the REDD+ context.

Table 2.1: Types of Engagement Process (Degree of Participation in REDD+)

\begin{tabular}{|l|l|}
\hline Types of Engagement & Description \\
\hline Empowerment & $\begin{array}{l}\text { Transfers control over decision making, } \\
\text { resources \& activities }\end{array}$ \\
\hline Joint decision-making & $\begin{array}{l}\text { Joint collaboration with shared control } \\
\text { over a decision }\end{array}$ \\
\hline Collaboration & $\begin{array}{l}\text { Joint activities without decision making } \\
\text { authority and control }\end{array}$ \\
\hline Consultation & $\begin{array}{l}\text { Two-way flow of information and } \\
\text { exchange of views }\end{array}$ \\
\hline Information sharing & One-way flow of information \\
\hline
\end{tabular}

(Source: UN-REDD Programme, REDD+ Academy (2016). "Learning Journal 11 - Introduction to Stakeholder Engagement.”)

According to Gebara (2013), there are two distinct perspectives on participation: "participation as a means" which means participation for effectiveness in implementing the REDD+ programme and "participation as an end" which means participation for the empowerment of certain groups and for equity. Gebara (2013) found that to achieve the ultimate goals of REDD+, the local community needs to be included in the whole process of the REDD+ scheme. In the study of the Juma Sustainable Development Reserve project in Brazil, the paper highlights the importance of local participation in the REDD+ benefit-sharing mechanism by examining the degree of local participation in the project. The study argues that the implementation of REDD+ is more likely to succeed if benefit-sharing mechanisms are carefully designed and implemented through considering democratic and active local participation (Gebara, 2013). The study also argues that the needs of households who rely on the forests for their livelihoods should be considered and their benefits clearly identified (Gebara, 2013). To do so, it is crucial to include local participation in REDD+ policy and decision-making. In addition, the benefit-sharing of carbon value may not be distributed equally or fairly among different stakeholders if land tenure is not secure (Larson et al., 2013). Research in Nepal found that little attention is paid to governance issues such as carbon rights and "fundamental 
aspects of participation, equity and fairness remain unaddressed" (Ojha et al., 2013, p. 216).

\subsubsection{Land tenure and forest-dependent communities}

The existing literature highlights that there is a need to clarify land tenure in the earliest stage of REDD+ implementation (Davis, Daviet, Nakhooda, \& Thuault, 2009; Phelps et al., 2010; Sunderlin, Larson, \& Cronkleton2009). Davis et al. (2009) reviewed 25 REDD+ implementing countries to find challenges in forest governance and discovered land tenure is a major challenge in most countries. They suggested tenure security issues need to be addressed, discussed comprehensively and responded to in the REDD+ Readiness Plan to prepare for its implementation (Davis et al., 2009). Similarly, Sunderlin et al. (2009) argue that tenure security is "a key precondition for successful implementation of REDD+" (Cronkleton, Bray, \& Medina, 2011, p. 456). This section focuses on land tenure issues in the REDD+ context because land tenure is an issue particularly relevant in Myanmar where officially, the government still owns all land.

Larson et al. (2013) and Poudel et al. (2014) argue that REDD+ has provided some new benefits and opportunities for land tenure security and rights, but there are still challenges to recognizing customary rights and limiting customary access rights to forests. Moreover Larson et al. (2013) and Sunderlin et al. (2009) argue that secure and clear land tenure rights is one of the key elements for making payments through REDD+ schemes. If there are unclear or insecure tenure rights, or conflict on land tenure and land boundary mapping, REDD+ can lead to unequal benefit-sharing (Sunderlin et al., 2009) and more powerful actors could gain uneven REDD+ benefits compared to local communities (Larson et al., 2013; Leggett \& Lovell, 2012). Larson et al. (2013) believe that REDD+ can be an opportunity for land tenure reform, but could also bring challenges like recognizing customary land and rights for indigenous peoples and communities living in forests. This is similar to Sunderlin et al. (2014) who highlight that REDD+ can support addressing land security issues; they argue that securing land tenure rights is one of the key elements in the REDD+ scheme, particularly in developing a benefit-sharing mechanism that makes performance-based payments (Sunderlin et al., 2014). 
In addition to the land tenure problem, Leggett and Lovell (2012) argue that it is essential to specify carbon ownership. They explain that identifying land tenure could be clearer and less challenging than defining carbon tenure. For example, in PNG, the vast area of lands and forests are customarily owned, but the government could still claim carbon ownership (Leggett \& Lovell, 2012). In Cameroon, people only have legal ownership of the trees they have planted; the government can still claim ownership of the land itself to benefit from the REDD+ incentives (Cotula \& Mayers, 2009). Therefore whether or not land tenure is secure, if the ownership of 'carbon rights' are not clarified, there will be an issue for forest-dependent communities or indigenous people who contribute to forest management and carbon emission reductions (Larson et al., 2013; Leggett \& Lovell, 2012). In Myanmar, according to the Constitution (2008), all land is owned by the State, but land tenure rights, use of land, and responsibilities to land management are associated with different actors who have legal or customary rights (Htun, 2009). As in other countries, carbon ownership rights have not yet been addressed.

\subsubsection{Integrating REDD+ into CFM}

While forests in most developing countries are government owned, in practice much of this forest land is actually controlled by communities (Agrawal, Chhatre, \& Hardin, 2008). A vast area of world forests are classified as community-controlled forests (Bluffstone et al., 2013). More than 10\% of the world's forests are owned and are under communities' administration and about $18 \%$ of forests worldwide are used by local communities (Chhatre \& Agrawal, 2009; Poudel et al., 2014). According to Bluffstone et al. (2013), community-controlled forests (CCFs) and community forest management (CFM) refer to a type of property or legal rights over forests where the communities have rights to control the forests as well as rights to gain benefits from forests.

Given the high percentage of forests controlled by communities globally, the relationships between REDD+ and CFM need to be carefully considered. In particular, goals of carbon maximisation, forest conservation and forest-dependent communities' livelihoods may come into conflict (Bluffstone et al., 2013). There is a wide range of ways that community control over forests is exercised. Arrangements vary in terms of access rights, benefit-sharing, and who sets rules and regulations. As such, there is a spectrum of arrangements that fit within community forest management, and the 
possibilities for forest protection and poverty reduction are equally varied (see for example, Bluffstone et al., 2013).

\subsubsection{The relationship between REDD + and CFM}

Existing research demonstrates that REDD+ implementation could destabilise wellfunctioning community forest management (CFM) systems unless REDD+ is designed and implemented carefully (Bluffstone et al., 2013; Newton et al., 2015; Poudel et al., 2014). As discussed previously, many have stressed the danger of not collaborating fully with local communities, but CFM extends this collaboration out to other actors such as local governments especially in cases where the central government might become a dominating party in the process. The complex relationships between CFM and REDD+ are demonstrated by existing research in Nepal and Tanzania, where all REDD+ projects are being developed in or close to new community forestry initiatives (Newton et al., 2015). The study demonstrates that many people consider REDD+ implementation brings institutional advantages to Nepal, which already has a wellestablished community-based forest management system with strong policies (Bushley $\&$ Khatri, 2011). However, some people are concerned about whether REDD+ implementation destabilises Nepal's forest governance or encourages the Government of Nepal to centralise forest management. The study found that local governments and communities were excluded in the implementation of REDD + and the implementation and decision-making processes were overly influenced by some key and powerful actors like the REDD+ implementing government agency, technical consultants, and donor agencies. Further, the study found there is a lack of attention by the government to the rights and interests of communities and to designing safeguards to protect the rights and needs of communities. Therefore, they emphasize the importance of local governments and communities in the REDD+ process in Nepal and stress that their needs should be carefully considered as part of the REDD+ initiative (Bushley \& Khatri, 2011).

Newton et al. (2015) and Poudel et al. (2014) highlight some opportunities for integrating REDD+ with CFM. For example, REDD+ funding can be used to overcome the financial barriers for CFM sites in developing countries (i.e. the financial needs for technical resources to conserve the forests, capacity building etc.). However there are also issues involved in integrating these two programmes, and Newton and colleagues (2015) highlight four of these. First, the focus of REDD+ on carbon maximisation could 
change the rules of forest use by communities; communities may be restricted from accessing the forests and its resources for their livelihoods (see also Ojha et al., 2013). Second, financial incentives from the international donor agencies and rewards for carbon maximisation may lead to recentralisation in forest management by the government, which may weaken CFM structures. Third, an equitable benefit-sharing mechanism between communities and governments over forest rights and resource use should be carefully designed. And fourth, the sustainability of funding for REDD + pilot projects is uncertain and it is unclear whether or not pilot projects at the sub-national level will support the national level REDD+ project. These kinds of uncertainties around REDD+ pilot projects or demonstration areas could harm the relationship between communities, CSOs and government agencies, and forest communities or other stakeholders could believe they are being given false promises by their governments concerning REDD+ projects (Newton et al., 2015).

Newton and his colleagues discuss why REDD+ should be integrated into community forests. They also argue that the CFM system alone is not enough for maintaining forests. They contend that fully integrating REDD+ into CFM systems, from forest communities through to central governments, is the only way to marry these programmes in a way that helps to sustain forests (Newton et al., 2015). However the risks and challenges in integrating both REDD + and CFM policies in forestry management remain across developing countries where such things as forest tenure is poorly defined (Bluffstone et al., 2013; Newton et al., 2015; Poudel et al., 2014). The uncertainty over forest tenure can lead to conflict over access and control (Bluffstone et al., 2013). This is related to a second problem, that governments may be reluctant to delegate appropriate power and responsibility to communities (Bluffstone et al., 2013). While these issues exemplify the difficulty of integrating REDD+ into existing CFMs, they also underscore the importance of this integration.

\subsubsection{Political will}

As a final note on governance issues, Somorin et al. (2014) look at the problem of weak governance and a lack of high level political will and commitment towards REDD+ development. In their study in Cameroon, they found that "there is a need to balance the current political will with the required implementation capacity" (Somorin et al., 2014, p. 94). Although they acknowledge there are barriers in institutional and technical 
capacity to fulfil the requirements of the REDD+ mechanism, they believe actors should remain positive and be strong in their commitment (Somorin et al., 2014). In addition, a national government's leadership and coordination is a key to the success of the REDD+ mechanism in the long-term. Such state or national level leadership is crucial to create enabling environments and conditions for all REDD+ concerned stakeholders to interact with each other and engage with REDD+, and to coordinate with external actors (i.e. to build external partnerships with donor groups and other development partners) (Somorin et al., 2014).

\subsection{Synopsis}

This chapter has reviewed literature that highlights different storylines around REDD+. These storylines help to explain how different stakeholders involved in the programme perceive its implementation. There are some promises that REDD+ can deliver a winwin situation and can bring opportunities to address climate change issues, financial rewards to REDD+ implementing countries, and benefits to manage forest sustainability. But there are critiques and competing discourses around REDD+. Many scholars regard REDD+ as a neoliberal mechanism designed to impose carbon colonization on developing countries. Other critiques are based on issues which have emerged during its implementation such as land insecurity, restriction of forest access to forest-dependent communities, unclear benefit-sharing mechanisms among different stakeholders, power imbalances between stakeholders, and seeing REDD+ as a divider of North and South. This literature will be picked up on again in Chapter Five and the issues identified will be explored in relation to Myanmar. 


\section{Chapter Three: Methodology}

This chapter explains the methodology adopted to conduct this research and discusses why a post-structuralist political ecology approach fits with my research. I aligned my methods with a post-structuralist political ecology by adopting a case study-based approach that involved conducting and analysing semi-structured interviews with a range of participants. Firstly, I explain why constructivist epistemology with a poststructuralist political ecology framework fits my research. Then I explain how the qualitative case study approach applies to this work. Following this, I discuss how I position myself as a researcher, issues around positionality and reflection throughout the fieldwork, and issues around power relations among and between my participants and myself. Next, I highlight health and safety concerns for myself and my participants and follow this with an explanation of the choice of project locations and the recruitment process I used to select the participants. I also discuss how I addressed ethical considerations to ensure my research is accountable to participants and cognizant of power relationships. Finally, this chapter explains data usage, management, and analysis.

\subsection{Constructivist epistemology}

This thesis examines people's perspectives on REDD+ implementation in Myanmar, as well as interactions between different stakeholders in the REDD+ initiative. The research is conducted through a constructivist epistemological approach. This is an approach that acknowledges there is no one objective truth in the world that is waiting to be discovered. Instead, the role of the researcher is to understand the complexity of situations and the variety of ways that truths are constructed. "Knowledge is socially constructed, not discovered" through people's interactions with the surroundings (Denzin \& Lincoln, 2011, p. 107). Holstein and Gubrium (2011) state that social, political and cultural contexts shape individuals' perceptions and how they create knowledge and meaning around them. Thus, different people see things differently based on historical and cultural contexts and their beliefs and experiences. Constructivism enables me to acknowledge different perceptions through my interactions with the participants (Creswell, 2014; Guba, 1990). A constructivist worldview is relevant to a qualitative methodology where I can interpret the meanings of the views of my participants (Creswell, 2014). Researchers who use this approach 
interact with the participants in-depth and through this process, share in a construction of knowledge from the participants' perceptions of reality and truth.

\subsubsection{Post-structuralist political ecology and REDD+ in Myanmar}

My study looks at the linkage between environmental conservation and the REDD+ initiative in Myanmar. Drawing on a post-structuralist political ecology approach helps me to identify competing discourses that shape who stakeholders are and how they can engage with the readiness stage. There is a large body of literature that highlights how REDD+ stakeholders perceive the initiative and their level of interest and participation in REDD+. REDD+ discourses have evolved among different stakeholders based on their interests and beliefs (Bluffstone et al., 2013). By reviewing existing literature around REDD+ discourses and drawing on the storylines conceptualised by Vijge (2015), this thesis focuses on three storylines to analyse how stakeholders in Myanmar perceive the REDD+ readiness phase. The three storylines are a safeguards storyline, a co-benefits storyline, and a carbon storyline. In the REDD+ context, the terms: 'discourse' and 'storyline' can be used interchangeably.

I analyse the linkages between international and local institutions as well as how different stakeholders are involved in the REDD+ readiness stage in order to implement REDD+ effectively in Myanmar. Existing research shows that the interests of different stakeholders on REDD+ are competing; at the same time they are collaborating on different levels in implementing REDD+ (van der Hoff et al., 2015; Vijge, 2015). Therefore it is important and timely to look at how Myanmar is approaching its implementation and how different actors perceive the REDD+ initiative. A discourse or a set of storylines is constructed by different actors at various levels of governance involved in REDD+ (Vijge, 2015). While the global interest of REDD+ is for carbon commodification, some stakeholders such as forest-dependent communities are interested in non-carbon values like, for example, biodiversity in the context of Indonesia and Nepal (Astuti \& McGregor, 2015; Bastakoti \& Davidsen, 2017). The following section outlines my research method for investigating these competing ideas about REDD+. 


\subsection{Research methods}

\subsubsection{Semi-structured interviews}

I carried out semi-structured interviews with different stakeholders involved in the REDD+ readiness stage to find out their perspectives on REDD+ implementation in Myanmar. Under a qualitative approach, semi-structured interviews are an appropriate method to explore the participants' perspectives, experiences and meanings (Creswell, 2014; Limb \& Dwyer, 2001). Semi-structured interviewing allowed me to prepare the questions ahead of time as well as allowed for in-depth face-to-face interactions with the participants. I provided the interview guide to my participants prior to the interview so that they could anticipate what would be covered during the interview. This guide then served as a reminder or an aide-memoire for the discussion (Thomas, 2013). Semistructured interviews allow preparation time for both interviewers and interviewees and allow participants and the interviewer to bring up new questions and to have flexibility in the conversations based on the participant's responses (Cohen \& Crabtree, 2006; Hay, 2010). Therefore, I was able to explore ideas and themes that arose during the interviews, and create more a comfortable or relaxed environment for my participants (Bernard, 2000; Thomas, 2013). I combined semi-structured interviews with a case study approach.

\subsubsection{Case study approach}

A case study is the most useful way to conduct an intensive study of a single or a small number of observations (Gerring, 2007). Hay (2010) states that

Case study methodology is a powerful means by which to both (1) understand the concrete and practical aspects of a phenomenon or place, and (2) develop theory (...) That is, case studies may be used to understand and solve practical problems relating to the case alone, and they may be used to test, falsify, expand, or generate explanatory theoretical concepts (Hay, 2010, p. 95).

The depth of understanding gained may provide information to solve practical problems associated with a specific case (Evans et al., 2014; Hay, 2010; Thomas, 2013).

The case study method also provides an opportunity for researchers to explore a case within a specific context because it provides snapshots when it is difficult to look at a larger population or sample: 
In most cases, a case study method selects a small geographical area or a very limited number of individuals as the subjects of study. Case studies, in their true essence, explore and investigate contemporary real-life phenomenon through detailed contextual analysis of a limited number of events or conditions, and their relationships (Zainal, 2007, pp. 1,2).

This research helps to develop detailed understandings of how different stakeholders engage with and collaborate towards implementing REDD+ in Myanmar, and, more broadly, aims to contribute to the development of better policy with regards to REDD+ implementation in developing countries. Therefore, a case study investigation is useful to gain a greater and detailed understanding of a specific context at a specific place and at a certain period of time.

Currently there is no in-depth research conducted on REDD+ implementation in Myanmar. REDD+ was initiated by the UN with the intention of tackling climate change issues, yet the literature points to a number of issues relating to REDD+ in developing countries, like land tenure for example (Bluffstone et al., 2013; Larson et al., 2013). Studying a specific place in-depth as a case study helps to gain a rich and detailed understanding and fits with a post-structural approach that seeks to understand power relations and competing knowledge. My research examines and investigates how different stakeholders engage with REDD+ readiness activities by studying the Bago Region and Shan State as case studies of REDD+ pilot projects (REDD+ demonstration sites).

There are currently REDD+ demonstration areas in five different regions in Myanmar: Ayeyarwady, Bago, and Sagaing regions, and Shan and Kachin states. There are different forest characteristics and biodiversity in each region and state (MOECAF, 2015b). Before conducting the fieldwork research, I did a preliminary review on where the REDD+ projects were established in Myanmar and which stakeholders were involved in the current stage of the implementation. There was a limitation in accessing the information online and I found it challenging to uncover relevant information prior to the fieldwork, but I did find five REDD+ pilot project areas on-line ${ }^{5}$. Among them were, the Ayeyarwaddy and Bago Regions located in the southern part of Myanmar

\footnotetext{
${ }^{5}$ I found "Myanmar REDD+ Readiness Roadmap (2013)" which was briefly explained in Chapter One: Introduction when I gave a contextual information about REDD+ development in Myanmar. I also found some powerpoint slides that the Forest Department made concerning with forestry sector and the introduction of REDD+ in the country.
} 
close to Myanmar's business city, Yangon. The other regions were: Sagaing located in the middle part of Myanmar; Kachin state in upper Myanmar; and Shan State in the eastern part of Myanmar. There are a lot of environmental issues in all the regions and states because of deforestation, agriculture, infrastructure development (for example the construction of dams and roads) and mining activities. Because of civil wars between ethnic armed groups and the Myanmar military in Kachin state and the northern part of Shan State, I chose not to do fieldwork there.

I selected the Bago Region because the Bago range (Bago Yoma) is one of the richest forest areas in Myanmar. It used to be covered by forests that included teak, but extensive logging has resulted in deforestation and forest and biodiversity degradation. This provides an interesting case study for REDD+ implementation as there is an opportunity to protect the remaining forest. As I needed to choose one specific area in the Bago Region, I approached the Forest Research Institute (FRI), a key implementing agency, to seek more information. I found out about a location of one REDD+ project named "FD-KFS REDD+ Project" in Kyaut Ta Gar Township in the Bago Region (Figure 3.1). After proposing to the Forest Department (FD) that I conduct my research there, I visited the township forest department in Kyaut Ta Gar Township and I also visited a village called Hpa Do in that region. 


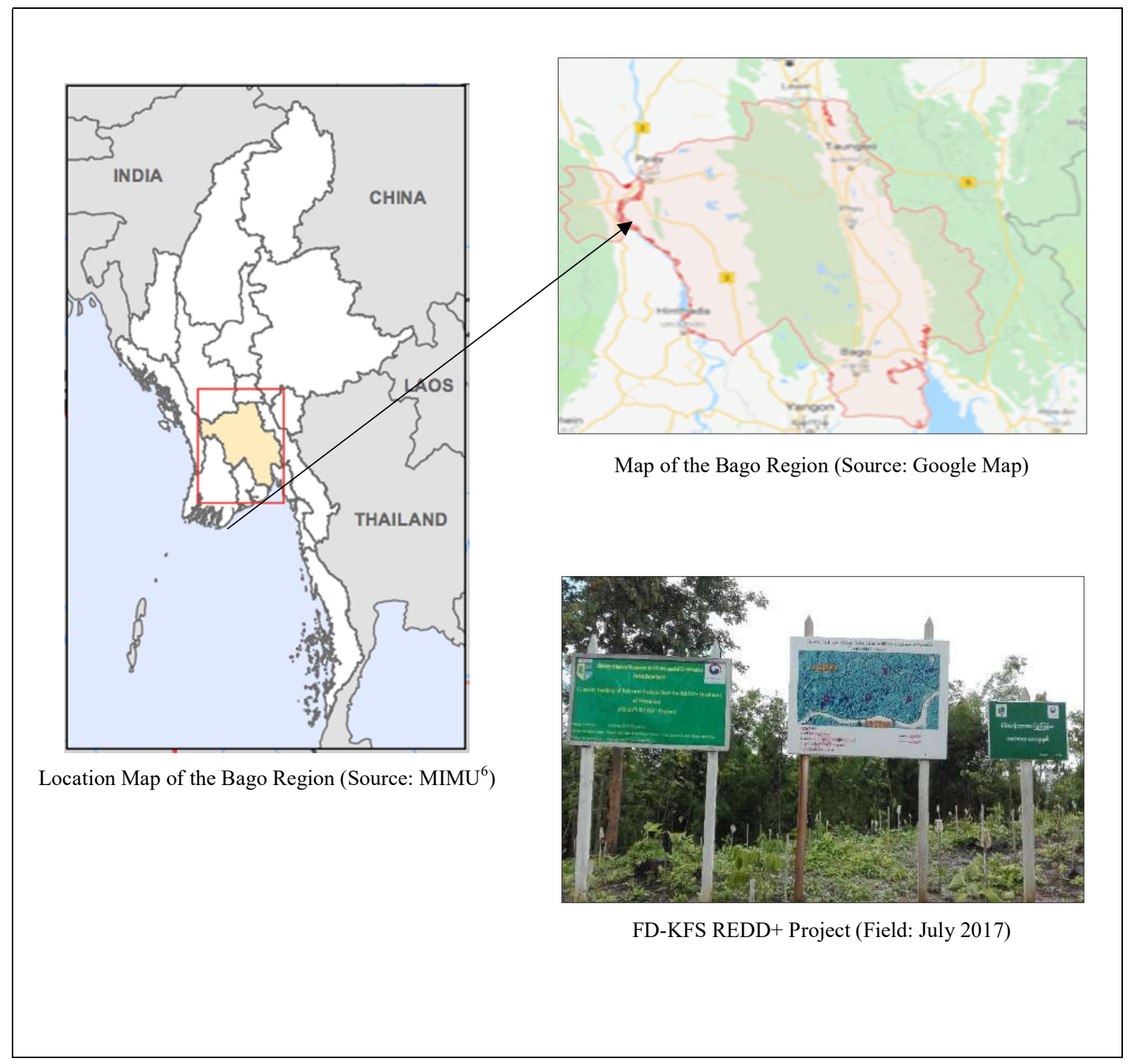

Figure 3.1: Location Map of Case Study One (Bago Region)

After proposing to study in Kyaut Ta Gar Township and visiting Hpa Do village, I realized that the project area is not nearby this village and the local forest department has limited knowledge on how the REDD+ project is being implemented. Neither the local (township level) government nor the local communities I visited were aware of the national government's REDD+ initiative agenda. I did not have enough information and did not get enough support at the local government level to go to the village near the project area and so I did not meet the communities there. However, I did meet one officer from the local forest department and villagers from Hpa Do village who are currently involved in REDD+ related trainings and workshops.

${ }^{6}$ MIMU (Myanmar Information Management Unit) Retrieved from http://themimu.info/ 
The main reason for selecting Hpa Do village, although it is not near the project, was that before I went to the Bago Region, I met two villagers from that village in a REDD+ training workshop called "National level capacity development for indigenous peoples in Myanmar" offered by one local NGO in June, 2017 in the capital city of Myanmar. Based on their presence at the workshop, I assumed they represented indigenous peoples living close to the project area and were from the local communities who rely on the forest where the programme is being implemented. As it turned out, these two people were from Hpa Do village, which, while close to the forest, is not necessarily a community of villagers that rely on the forest. However, it is still a community with a strong interest in the REDD+ initiative. These two villagers offered me a place to stay when I visited their village in July 2017. Without their support, I would not have been able to observe this project location alone as it is a long journey and difficult to reach without locals' support. So, I was fortunate to be able to observe the project area at least, although I did not directly interact with the specific village close to the project site.

Before I went to the field, according to my initial research plan, I proposed to study one specific case in the Bago Region. But during my fieldwork, after meeting with a country national coordinator and hearing from him about REDD+ activities, it became clear that the REDD+ projects in each region are different and it was important to understand these differences. For example, one big difference is that in the Bago Region, the government initiated a REDD+ project in the state-owned reserved forest ${ }^{7}$ where there is no community who currently depends on that forest as that area already has restricted access $^{8}$.

In contrast, the demonstration project in Shan State is in an area where the communities rely on forest access for their livelihoods. It was very important to examine what impact REDD+ schemes are having on community access, and how community access might

\footnotetext{
${ }^{7}$ In Myanmar, there are five types of state-owned reserved forest. According to the Forest Law (1992), they are (a) commercial reserved forests; (b) local supply reserved forests; (c) watershed or catchments protection reserved forests; (d) environment and biodiversity conservation reserved forests; and (e) other categories of reserved forests (MOECAF, 1992). The reserved forests in the Bago Region were intended for "commercial reserved forest" as the forests are covered with teak and 'pyinkado' timber (Botanical name: Xylia dolobriformis) but commercial logging is banned at the moment (Personal Communication with a government staff, December 2017).

${ }^{8}$ The reserved forests in the Bago Region was intended for "commercial reserved forest" but access for logging has been banned at the moment and local communities have their own land (Personal communication with one government staff from the Forest Department in December 2017 and based on the field work observation in June, 2017.)
} 
shape the success of readiness activities. In particular, I wanted to visit a community which depends on the forest to better understand their perception of REDD+ implementation and how they engage with this REDD+ initiative. To that end, I studied a case in Shan State as well. I was able to deepen my understanding of how relevant stakeholders engage with this REDD+ programme. I observed how the communities in Shan State access the forest, what they do to protect the forest, how they understand the REDD+ initiative, and how they are involved in the REDD+ readiness stage. This additional case study happened unexpectedly towards the end of my fieldwork period. ${ }^{9}$ By analysing the two very different case studies, I was able to gain greater insights into how Myanmar is approaching the implementation of REDD+ (Thomas, 2013).

\subsubsection{Conducting a participant observation}

The central government supported my visit to Shan State one week before I was to return to Aotearoa New Zealand. A late invitation to Shan State, and time constraints, meant I was unable to establish the degree of rapport and comfort required for semistructured interviews. Instead, I conducted participant observations to better understand the REDD+ implementation phase and people's perceptions of it. During these observations, I engaged with my participants both informally and formally and recorded the information gained from them. I visited two of the three project sites in Pindaya Township, Shan State, and was able to observe the initial stages of the REDD+ projects, including tree planting. I was also introduced to the heads of three villages and some village members during this time. Through informal conversations with them, I was able to better understand how their communities are interacting with REDD+ initiatives. In terms of documenting my observations, I did not use any audio or video recording, nor did I record any names of people I spoke with. Instead, I took detailed observational field notes during this visit. Everyone I talked to was informed about who I was, why I was there and what my research project was about. My observations provided invaluable richness to my understanding of the challenges faced by these communities and governments as REDD+ is rolled out.

\footnotetext{
${ }^{9}$ I found out that the government staff in Shan State, who could assist my visit, would not be available in a certain period of time and I did not have time to seek permission from the ethics committee before undertaking this additional case study. I successfully sought retrospective approval from the VUW Human Ethics Committee to add this additional case study (Appendix 1).
} 


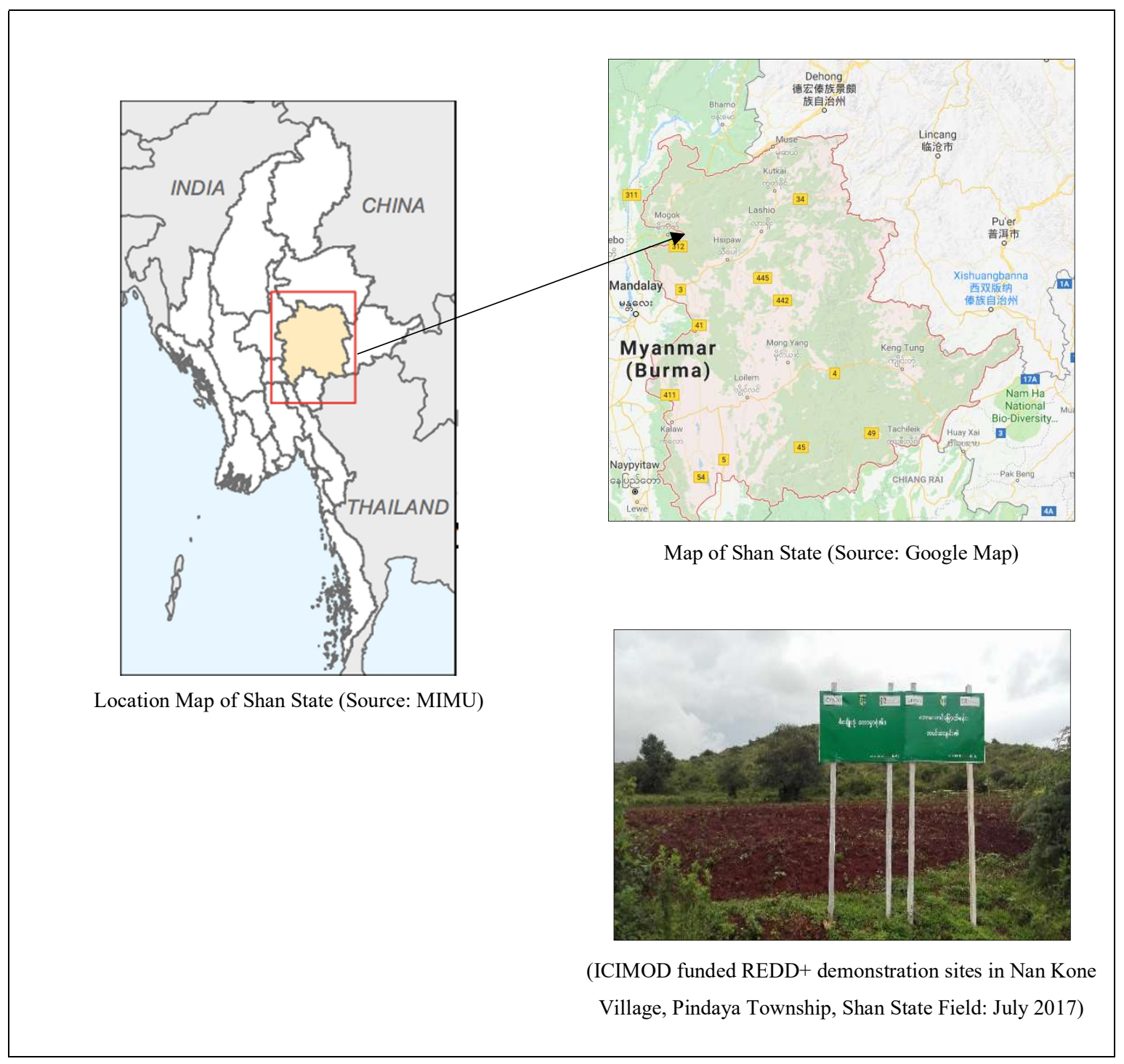

Figure 3.2: Location Map of Case Study Two (Shan State)

\subsection{Positionality, reflexivity and power relations}

It is important to understand the issues of positionality, reflexivity, and power relations during research fieldwork. As a researcher, my own positionality should be critically considered while undertaking fieldwork observations and interviews, as a means to reflect on relations of power between myself (as a researcher) and my participants (researched). According to Chacko (2004, p. 52), "positionality refers to aspects of identity in terms of race, class, gender, caste, sexuality and other attributes that are markers of relational positions in society, rather than intrinsic qualities". 
Positionality is engaged with through a process of reflexivity. According to Sultana (2007, p. 376), "[r]eflexivity in research involves reflection on self, process, and representation, and critically examining power relations and politics in the research process, and researcher accountability in data collection and interpretation.”

According to Hay (2010, p. 32), power exists in all social relations and cannot be eliminated in any research. It is critical to acknowledge power differences among the research participants as well as between myself and my participants. Sultana (2007) also states that

"[Emphasis should be paid to] non-hierarchical interactions, understanding, and mutual learning, where close attention is paid to how the research questions and methods of data collection may be embedded in unequal power relations between the researcher and research participants" (Sultana, 2007, pp. 375-376).

Hay (2010, p. 31) also suggests that it is necessary for a researcher to critically reflect on their own position through self-critical awareness throughout the research.

Applying a qualitative approach, I constantly needed to reflect about my role in the research process, how I shaped the questions, how I interpreted the answers, how I interacted with my participants and how they interacted with each other, and how I navigated the study (Creswell, 2014). It is important for us researchers to inform their participants about the research, why "[o]ur research is needed, that we have the skills and determination to conduct the research, and that we are trustworthy" $(\mathrm{H}$. Scheyvens, Scheyvens, \& Nowak, 2014, p. 126). While it is impossible to ever fully know how my positionality has shaped this research, it is important to reflect on it and be constantly mindful of it during my research process.

During my field work in the Bago Region, I was often treated as an "insider", or belonging to the community, because I shared the same ethnicity as members of the region. People were open with me and because of our ethnic connections, considered me to be a family member. This position made my research much easier and I got help from the villagers to visit to the REDD+ project site without the government's support. Nevertheless, I was very careful to position myself as a researcher and to be clear about the aims of my research. 
At the same time, I saw myself as an outsider because of growing up in a city that is socially, geographically and economically different from where my study took place, and because I am currently a student studying abroad.

It was crucial to introduce myself in a way that stated who I am to my potential participants. My informants were interested in who I am and what I did (where I worked) before studying overseas. So after introducing myself, I clearly stated that I am a student currently studying overseas and explained my research purpose in detail. In Myanmar, the national government's support is often important for a researcher to conduct research. The reason for this, as explained to me by a government official, is that the government works under a chain of command and is not democratic. Therefore, the national government is all powerful within the country and the sub-national governments follow its instructions. Some of my participants, particularly government staff at the sub-national level, may have hesitated to be open with me when answering questions if they felt I had not obtained permission from the central government. As long as they knew they were allowed to assist me as a researcher, they felt secure to collaborate with me. However, this dependence on getting approval from the central government may have also influenced what kind of information they felt able to share with me. As Myanmar is transitioning to a more democratic form of government, people are starting to feel increasingly comfortable criticizing certain government policies. However, there is still some apprehension about being overly critical, especially with a person that they do not know well. In the interpretation of interviews and observations, it was important to be mindful of this political and cultural context.

In my country's context, social and professional networks are very important and useful, so it was imperative to engage with my participants and build trust with them. Sometimes it is easier to approach people when there is someone whom you know internally or there is some connection. Nonetheless, the most important thing for me to do was to express clearly and carefully who I was and why I was there. I needed to anticipate ethical considerations throughout my study in order to protect the rights of my participants and to produce ethical and accountable research. Concurrent with the importance of ethical considerations was the equally important consideration of the health and safety of my participants and myself. 


\subsection{Health and safety}

As I am a young female student, I avoided traveling or being alone in isolated locations especially at night. It was also important to make constant contact with my family and friends and my supervisor about my fieldwork itinerary. For my interviews I needed to consider a place where both my informants and I were comfortable and secure (Flowerdew \& Martin, 2005, p. 118). Keeping this in mind, I interviewed my participants in public areas and at places convenient for them, such as their workplace. Being mindful of the political and cultural context of limited freedom of speech in the country, I did not mention when certain participants, who were crucial to the research, were critical about issues not pertaining to REDD+ implementation.

\subsection{The project location and the process of recruiting participants}

It is important to develop a comprehensive plan and solid arrangements before doing the field research. It is also important to adjust the plan according to experiences in the field. Therefore, field research requires finding a balance between rigidity and flexibility (R. Scheyvens, Storey, \& ProQuest, 2003). For the semi-structured interviews, I recruited 11 participants and I was able to talk to two additional organizations (one non-government organization and one donor agency) informally. To get an in-depth understanding of REDD+ stakeholder engagement, my interviewees were from a range of sectors involved at the national and regional levels.

Bearing in mind the importance of being flexible and the status of Myanmar's REDD+ activities, I was unable to interview anyone from the private sector because the initiative is in the early stages and the private sector has yet to show any interest. Apart from that, I was able to recruit stakeholders from the community and official government levels, environmentalists, and international organizations. The summary of the interview list is shown in Table 3.1. I interviewed four government staff at the national level, and one local officer from the regional government. In the Bago case study, I intended to recruit around four local community people who depend on the forest near the project area, but I only conducted one semi-structured interview with one of the two Hpa Do villagers whom I had met at the workshop. The participant I talked to had an understanding of REDD+ in that specific place in the Bago Region and he had been involved in the 
REDD+ workshops and trainings organized by the government and a local NGO named "POINT" (Promotion of Indigenous and Nature Together) ${ }^{10}$.

As discussed previously, I conducted my fieldwork for the Shan State case study through participant observations. There, I met three village heads and other villagers, and this allowed me to explore how local communities perceive REDD+ as well as their level of understanding and participation in the programme. I interviewed representatives from a donor agency and partner, UN-REDD (UNDP), one person from a local nongovernment organization, an environmentalist, one person from an international nongovernment organization, and two academics. I also had an informal meeting with Korean Forest Services (KFS) which supports funding for the REDD+ project in the Bago Region.

To get a range of perspectives on REDD+ implementation in terms of gender, I tried to recruit both male and female participants, but there were only two female participants. However this is approximately proportional to the current ratio of women to men in leadership roles in the government and in NGO's in Myanmar. Since my participants were usually people of influence in the REDD+ programme, the lack of female participants adequately represents the stakeholders ${ }^{11}$.

To recruit participants from the government departments, I sought permission from the government senior level. This protected the government staff who are not at the senior level and is a necessary part of the process in Myanmar to interview any government staff member. To recruit participants from non-government organizations and donor agencies such as the UNDP, I approached these organizations by email and phone calls. I informed them about the nature of my project and sought permission to recruit participants for the project.

\footnotetext{
${ }^{10}$ POINT is a local non-governmental organization (NGO) in Myanmar which was established in 2012. The organization works for the rights for indigenous peoples and environmental related issues. https://www.pointmyanmar.org/ It is also one of the key stakeholders in REDD+. This organization is the one which invited me to attend the REDD+ related workshop for indigenous peoples during my field research in June, 2017.

${ }^{11}$ The ratio of women to men in leadership positions in Myanmar is increasing and perhaps future research will, as a result, include female participants.
} 
Table 3.1: Research participants ${ }^{12}$

\begin{tabular}{|c|c|c|c|c|}
\hline Stakeholders & $\begin{array}{l}\text { Number of } \\
\text { participants }\end{array}$ & $\begin{array}{l}\text { Name of the } \\
\text { organization/ } \\
\text { Community }\end{array}$ & Code Name & Interview Date \\
\hline \multirow[t]{5}{*}{ Government } & \multirow[t]{4}{*}{$\begin{array}{l}4 \\
\text { (National level) }\end{array}$} & $\begin{array}{l}\text { National } \\
\text { government } \\
\text { official. } \\
\text { Forest Research } \\
\text { Institute, Ministry } \\
\text { of Natural. } \\
\text { Resources and } \\
\text { Environmental } \\
\text { Conservation }\end{array}$ & Participant 1 & 25-July-2017 \\
\hline & & $\begin{array}{l}\text { Ministry of } \\
\text { Agriculture, } \\
\text { Irrigation and } \\
\text { Livelihood }\end{array}$ & Participant 2 & 24-July-2017 \\
\hline & & $\begin{array}{l}\text { Ministry of } \\
\text { Energy and } \\
\text { Electricity }\end{array}$ & Participant 3 & 4-July-2017 \\
\hline & & $\begin{array}{l}\text { Department of } \\
\text { Mines, Ministry } \\
\text { of Natural } \\
\text { Resources and } \\
\text { Environmental } \\
\text { Conservation }\end{array}$ & Participant 4 & 25-July-2017 \\
\hline & $\begin{array}{l}1 \\
\text { (Township level) }\end{array}$ & $\begin{array}{l}\text { Forest } \\
\text { Department/ } \\
\text { Township Level } \\
\text { (Bago Region) }\end{array}$ & Participant 5 & 13-July-2017 \\
\hline $\begin{array}{l}\text { Development } \\
\text { partners/ } \\
\text { International Org }\end{array}$ & 1 & $\begin{array}{l}\text { UN-REDD } \\
\text { National } \\
\text { Programme } \\
\text { Office }\end{array}$ & Participant 6 & 30-June-2017 \\
\hline \multirow[t]{2}{*}{$\begin{array}{l}\text { Local and } \\
\text { International Non- } \\
\text { Government } \\
\text { Organizations }\end{array}$} & \multirow[t]{2}{*}{2} & $\begin{array}{l}\text { The Centre for } \\
\text { People and } \\
\text { Forests } \\
\text { (RECOFTC) }\end{array}$ & Participant 7 & 11-July-2017 \\
\hline & & $\begin{array}{l}\text { ALARM- } \\
\text { Advancing Life } \\
\text { and Regenerating } \\
\text { Motherland }\end{array}$ & Participant 8 & 17-July-2017 \\
\hline $\begin{array}{l}\text { Local Community } \\
\text { (Forest-dependent } \\
\text { community) }\end{array}$ & 1 & $\begin{array}{l}\text { Villager, Bago } \\
\text { Region }\end{array}$ & Participant 9 & 19-July-2017 \\
\hline Academic & 2 & $\begin{array}{l}\text { Department of } \\
\text { Agricultural } \\
\text { Economics, Yezin }\end{array}$ & Participant 10 & 29-June-2017 \\
\hline
\end{tabular}

\footnotetext{
${ }^{12}$ The nature of these stakeholders such as who they are, what their organizations do and what they want to achieve in relation to REDD+ (their expectation of REDD+) is explained in the next chapter: Chapter Four (Findings)
} 


\begin{tabular}{|l|l|l|l|l|}
\hline Stakeholders & $\begin{array}{l}\text { Number of } \\
\text { participants }\end{array}$ & $\begin{array}{l}\text { Name of the } \\
\text { organization/ } \\
\text { Community }\end{array}$ & Code Name & Interview Date \\
\hline & & $\begin{array}{l}\text { Agricultural } \\
\text { University }\end{array}$ & & \\
\cline { 3 - 5 } & & $\begin{array}{l}\text { Center for } \\
\text { Economic and } \\
\text { Social } \\
\text { Development }\end{array}$ & Participant 11 & 22-July-2017 \\
& & & & \\
\hline Total & $\mathbf{1 1}$ & & & \\
\hline
\end{tabular}

It took approximately 30-60 minutes for each interview. I made interview notes for some interviews and transcripts from some of the in-depth interviews, and I translated those transcripts into English. I only audio recorded some of the interviews - with my participants' consent. Three of my participants were not comfortable with their voices being recorded, so, I made notes in my field book based on the conversations.

\subsection{Ethical considerations}

All researchers are required to carefully consider the ethical implications of their aims and methods (Creswell, 2014; Hay, 2010, p. 27). Creswell (2014), mentions that there is increased attention to the ethical issues in research today and states further that ethical considerations demand that an interview only take place with the consent of the participant. To protect my participants, first I sought and received the University's Human Ethic Committee's approval for my fieldwork study prior to my fieldwork. The approval is attached as Appendix 1. I then sought permission from the government departments in Myanmar to recruit participants from the regional and township level government departments. One government official explained that government institutions have evolved from British colonial times and have been adjusted by the military regime and that it will take time to change this system in Myanmar (Personal communication with one government officer ${ }^{13}, 2$ October 2017).

I was fully cognizant of, and continually reflecting on, ethical issues throughout this research. I carefully explained the research to participants, including their rights and the confidentiality of their identities (Creswell, 2014, pp. 92,93). It was important to clearly outline the research plan and how the research findings will be communicated to the individual participants (Creswell, 2014). Some of my participants indicated that they wanted to receive the summary of the research findings when they gave their consent

${ }^{13}$ The officer is from the Ministry of Agriculture, Livestock and Irrigation. 
for the interview. Without putting any pressure on them to sign the consent form or participate in the study, I obtained my informants' consent. I planned to accept a verbal consent if I met a participant who was illiterate, but this was not needed.

I used pseudonyms for my participants' to protect their identity and maintain their anonymity. In some cases, participants are referred to by role, organizations or community rather than by name. However, I clearly explained to my participants, at the beginning of the study, that they should be aware that in such a small project, their identity might be obvious to others in their community. Some participants were willing for their names to be used in my study. Nevertheless, I have not used them in order to provide a layer of confidentiality. I also provided information about the study and the informed consent form in local (Myanmar) language so that my informants could understand clearly what the study is about and what they were consenting to. Having gathered my data and ensured my participants of their anonymity I proceeded to the analysis of my fieldwork research.

\subsection{Data usage, management and analysis}

From the completion of the thesis, all the interview data, summaries and any recordings will be kept securely in my password protected computer and in a safe place according to ethical considerations (Hay, 2010, p. 29); and they will be destroyed three years after the research ends. I will have backup data stored on a password protected hard disk and the transcripts and interview records are only able to be accessed by me and my supervisor.

\subsubsection{Transcribing the data}

Interviews were transcribed, and notes collated, before I analysed the data. All the transcripts and the summary of interviews are in the Myanmar language and I sent them to my participants for their review and comments.

\subsubsection{Data analysis}

A constructivist approach led me to apply qualitative analysis where knowledge and meanings of the participants are explored in-depth and socially created (Creswell, 2014; Gergen \& Gergen, 2008). By using the lens of a post-structuralist political ecology, this research employs discourse analysis to explore different meanings and perceptions of the participants, and to analyse power relations. By drawing on Foucault's idea of power, I did not look at power as a top-down relation; instead I looked at power as it 
can exist everywhere and how knowledge is produced among actors (Berg, 2009). I did a literature review that highlighted broader discourses that surround REDD + . Then I analysed my data for discourses that are unique to Myanmar. Based on my research questions, I identified themes to focus on. Themes can be organized by developing initial codes that can be retrieved from the research questions and literature (Hay, 2010). This coding system can also be used as interpretive or analytical codes. I was aware of the importance of being flexible and open concerning my research questions and accepted that I would hear new themes arise during the fieldwork.

The themes that emerge from my research are: (i) discourses around REDD+ (perspectives on REDD+); (ii) motivation and interest to be involved; (iii) expectations; (iv) opportunities and benefits; (v) challenges; (vi) level of participation; and (v) interaction and information sharing among different stakeholders. I also looked for any recommendations or suggestions from my participants about how they think the development of the REDD+ initiative could succeed in Myanmar. The next chapter will present the research findings. 


\section{Chapter Four: Findings}

The findings from 11 semi-structured interviews and participant observations during the field research are presented in this chapter. I will discuss my findings in relation to two key themes that emerged during my research. The first is the motivation and perceptions around the implementation of REDD+. The second is the governance of REDD + in Myanmar, such as the institutional arrangements, cross-sectoral coordination, land tenure and the designing of benefit-sharing among different stakeholders.

Key stakeholders in the REDD+ implementation phase can be identified as either internal or external, meaning either local actors within Myanmar, including the government, or those from international organizations (MONREC \& UN-REDD, n.d.). For this study, I have grouped the stakeholders into six categories: (i) the government sector (both national and local levels government); (ii) donors and development partners (both national and international development partners); (iii) non-government organizations (NGO)/ international non-government organizations (INGO); (iv) local or forest-dependent communities; (v) academics and environmentalists; and (vi) the private sector.

The participants recruited for this study are from all the sectors except the private sector. Since REDD+ is still in the early stages of development in Myanmar the private sector is not yet actively involved. However, the engagement and investment of the private sector in REDD+ projects is important "to ensure the adequate financing" and sustain REDD+ activities (Zhu, Ravnkilde, De Lopez, \& Romero, 2010, p. 11). To date, there has been more than four billion dollars of funding by developed countries to REDD+ implementing developing countries, and it is essential to scale up the private sector's participation in financing the programme (Zhu et al., 2010). The private sector can play a critical role in "funding (payment for environmental services), contribution to policy and legal framework development, and promoting of REDD+ implementation (carbon sequestration and avoided emissions)" (UN-REDD, 2013, p. 40). As REDD+ evolves in Myanmar, further research will be needed on the changing role of the private sector.

\subsection{Motivations to engage with and perceptions of REDD+ implementation}

Building on the contextual information and some background to the REDD+ initiative in Myanmar discussed in Chapter One, this section discusses the reasons which 
motivated people to become involved in the project. It also describes their perceptions and expectations of the initiative.

The UN-REDD Programme introduced the REDD+ initiative to Myanmar in 2011 and the Government of Myanmar initiated the programme in December, $2011^{14}$. As the REDD+ programme is new to Myanmar, UN-REDD became one of the main agencies which provided financial and technical assistance. The UNFCCC provides the guidelines to implementing the REDD+ initiative in developing countries. The leading government departments - the Forest Department (FD) and the Forest Research Institute (FRI) made a strong commitment to implement REDD+. The FRI is under the FD, which is one of the main departments in the Ministry of Natural Resources and Environmental Conservation (MONREC) ${ }^{15}$. The FD and FRI are key implementing agencies in the public sector and the rest of the ministries and government departments collaborate with them with the support of UN-REDD. The participants I recruited in this research are listed in Chapter Three. A brief introduction to each participant, their organization's role and what they expect from the initiative is presented in the following table.

Table 4.1: A brief introduction to participants

\begin{tabular}{|c|c|c|c|c|}
\hline $\begin{array}{l}\text { Participant } \\
\text { Code Name }\end{array}$ & $\begin{array}{l}\text { Role } \\
\text { Organization }\end{array}$ & $\begin{array}{l}\text { Nature of } \\
\text { organization }\end{array}$ & Role in REDD+ & 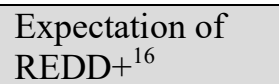 \\
\hline $\begin{array}{l}\text { Participant } 1 \\
\text { (Government) }\end{array}$ & $\begin{array}{l}\text { Director } \\
\text { FRI/ FD } \\
\text { (MONREC) }^{17}\end{array}$ & $\begin{array}{l}\text { "The FD is } \\
\text { responsible for the } \\
\text { protection and } \\
\text { conservation of } \\
\text { biodiversity and the } \\
\text { sustainable } \\
\text { management of } \\
\text { forest resources in } \\
\text { the country, } \\
\text { research and } \\
\text { development" (UN- } \\
\text { REDD, 2013) }\end{array}$ & $\begin{array}{l}\text { Key } \\
\text { implementing } \\
\text { agency }\end{array}$ & $\begin{array}{l}\text {-Sustainable } \\
\text { development } \\
\text {-Carbon credit }\end{array}$ \\
\hline $\begin{array}{l}\text { Participant } 2 \\
\text { (Government) }\end{array}$ & $\begin{array}{l}\text { Ministry of } \\
\text { Agriculture, } \\
\text { Livestock } \\
\text { and } \\
\text { Irrigation }\end{array}$ & $\begin{array}{l}\text { Responsible for } \\
\text {-the management of } \\
\text { agriculture } \\
\text {-management of } \\
\text { fisheries resources }\end{array}$ & Line ministry & $\begin{array}{l}\text {-To reduce } \\
\text { deforestation and } \\
\text { forest degradation }\end{array}$ \\
\hline
\end{tabular}

\footnotetext{
${ }^{14}$ The contextual information about REDD+ development in Myanmar and the status of its implementation was explained in Chapter One.

${ }_{15}$ Explained in Chapter One

${ }^{16}$ The participants' expectations are retrieved from the fieldwork findings.

${ }^{17}$ Forest Research Institute/ Forest Department
} 


\begin{tabular}{|c|c|c|c|c|}
\hline $\begin{array}{l}\text { Participant } \\
\text { Code Name }\end{array}$ & $\begin{array}{l}\text { Role } \\
\text { Organization }\end{array}$ & $\begin{array}{l}\text { Nature of } \\
\text { organization }\end{array}$ & Role in REDD+ & $\begin{array}{l}\text { Expectation of } \\
\text { REDD }+{ }^{16}\end{array}$ \\
\hline & & $\begin{array}{l}\text { within mangrove } \\
\text { forest } \\
\text {-river management } \\
\text { within forest areas }\end{array}$ & & \\
\hline $\begin{array}{l}\text { Participant } 3 \\
\text { (Government) }\end{array}$ & $\begin{array}{l}\text { Ministry of } \\
\text { Electricity } \\
\text { and Energy }\end{array}$ & $\begin{array}{l}\text { Responsible for } \\
\text {-distribution of } \\
\text { electric power } \\
\text { through hydro } \\
\text { power and natural } \\
\text { gases }\end{array}$ & $\begin{array}{l}\text { Line ministry. } \\
\text { The energy } \\
\text { sector is one of } \\
\text { the primary } \\
\text { areas to } \\
\text { mitigate GHG } \\
\text { emissions. }{ }^{18}\end{array}$ & $\begin{array}{l}\text {-Not very aware of } \\
\text { the REDD+ } \\
\text { programme } \\
\text { - However this } \\
\text { ministry is } \\
\text { determined to } \\
\text { reduce carbon } \\
\text { emissions from their } \\
\text { activities of } \\
\text { distributing power }\end{array}$ \\
\hline $\begin{array}{l}\text { Participant } 4 \\
\text { (Government) }\end{array}$ & $\begin{array}{l}\text { Department } \\
\text { of Mines } \\
\text { (MONREC) }\end{array}$ & $\begin{array}{l}\text { Responsible for } \\
\text { mining projects in } \\
\text { the forest areas }\end{array}$ & Line ministry & $\begin{array}{l}\text { To tackle climate } \\
\text { change issues }\end{array}$ \\
\hline $\begin{array}{l}\text { Participant } 5 \\
\text { (Government) }\end{array}$ & $\begin{array}{l}\text { FD/ } \\
\text { Township } \\
\text { Level }\end{array}$ & $\begin{array}{l}\text { "The FD is } \\
\text { responsible for the } \\
\text { protection and } \\
\text { conservation of } \\
\text { biodiversity and the } \\
\text { sustainable } \\
\text { management of } \\
\text { forest resources in } \\
\text { the country." } \\
\text { (Roadmap, 2013) }\end{array}$ & $\begin{array}{l}\text { Works under } \\
\text { the direct } \\
\text { control of the } \\
\text { national forest } \\
\text { department } \\
\text { Attends } \\
\text { workshop/ } \\
\text { awareness- } \\
\text { raising (believe } \\
\text { that these are } \\
\text { necessary in all } \\
\text { levels) }\end{array}$ & $\begin{array}{l}\text {-A platform for } \\
\text { empowering related } \\
\text { stakeholders in the } \\
\text { forest conservation } \\
\text { through } \\
\text { transparency and } \\
\text { good governance at } \\
\text { each level } \\
\text { (community, } \\
\text { district, and } \\
\text { national) } \\
\text {-Sourcing financial } \\
\text { and technical } \\
\text { assistance for forest } \\
\text { management and } \\
\text { conservation } \\
\text {-Local community } \\
\text { development and } \\
\text { eco-tourism from } \\
\text { saving forests and } \\
\text { biodiversity }\end{array}$ \\
\hline $\begin{array}{l}\text { Participant } 6 \\
\text { (Donor/ } \\
\text { International } \\
\text { Organization) }\end{array}$ & $\begin{array}{l}\text { UN-REDD } \\
\text { (A } \\
\text { collaborative } \\
\text { body of } \\
\text { FAO, } \\
\text { UNDP, } \\
\text { UNEP) }\end{array}$ & $\begin{array}{l}\text { Supports processes } \\
\text { for REDD+ } \\
\text { readiness and the } \\
\text { development of } \\
\text { national REDD+ } \\
\text { strategies in } \\
\text { developing }\end{array}$ & $\begin{array}{l}\text { Donor: } \\
\text { providing } \\
\text { financial and } \\
\text { technical } \\
\text { assistance to } \\
\text { GOM } \\
\text { Work closely }\end{array}$ & $\begin{array}{l}\text {-Land rights for } \\
\text { indigenous peoples } \\
\text { (ensure through } \\
\text { safeguards) } \\
\text {-Food security and } \\
\text { livelihoods for the } \\
\text { local communities }\end{array}$ \\
\hline
\end{tabular}

\footnotetext{
${ }^{18}$ The Government of Myanmar (GOM) is determined to reduce GHG emissions from the forestry, energy and transport sectors. The GOM submitted "Intended Nationally Determined Contribution INDC" to UNFCCC in 2015. INDC is a document which presents a country's mitigation actions, strategies, and adaptive efforts in climate change in accordance with Decision 1/ CP20 by the Conference of the Parties to the Convention. http://unfccc.int/focus/indc_portal/items/8766.php http://www4.unfccc.int/submissions/INDC/Published\%20Documents/Myanmar/1/Myanmar's\%20INDC.p df
} 


\begin{tabular}{|c|c|c|c|c|}
\hline $\begin{array}{l}\text { Participant } \\
\text { Code Name }\end{array}$ & $\begin{array}{l}\text { Role } \\
\text { Organization }\end{array}$ & $\begin{array}{l}\text { Nature of } \\
\text { organization }\end{array}$ & Role in REDD+ & $\begin{array}{l}\text { Expectation of } \\
\text { REDD }+{ }^{16}\end{array}$ \\
\hline & & countries & $\begin{array}{l}\text { with the FRI/ } \\
\text { FD }\end{array}$ & $\begin{array}{l}\text {-Result-based } \\
\text { payments }\end{array}$ \\
\hline $\begin{array}{l}\text { Participant } 7 \\
\text { (INGO) }\end{array}$ & $\begin{array}{l}\text { Training } \\
\text { Coordinator } \\
\text { (RECOFTC) } \\
\text { The Centre } \\
\text { for People } \\
\text { and Forests }\end{array}$ & $\begin{array}{l}\text { Started in } 2013 \text { in } \\
\text { Myanmar and work } \\
\text { in four thematic } \\
\text { areas concerning } \\
\text { within the forestry } \\
\text { sector } \\
\text {-Rights of forest- } \\
\text { dependent } \\
\text { communities } \\
\text {-Enhancing } \\
\text { livelihoods and } \\
\text { markets } \\
\text {-People, Forests, } \\
\text { Climate Change } \\
\text {-Transforming } \\
\text { forest conflict }\end{array}$ & $\begin{array}{l}\text { Delivering } \\
\text { awareness and } \\
\text { capacity } \\
\text { training to } \\
\text { grassroots level } \\
\text { (forest- } \\
\text { dependent } \\
\text { community) }^{19}\end{array}$ & $\begin{array}{l}\text {-As REDD+ } \\
\text { considers to identify } \\
\text { drivers of } \\
\text { deforestation, the } \\
\text { root causes of } \\
\text { deforestation will be } \\
\text { tackled and mitigate } \\
\text { through the REDD+ } \\
\text { programme. } \\
\text {-The forest- } \\
\text { dependent } \\
\text { communities and } \\
\text { the private sector } \\
\text { (as the private } \\
\text { sector also accounts } \\
\text { for deforestation) } \\
\text { will be able to } \\
\text { involve in accessing } \\
\text { forest resources and } \\
\text { managing forests } \\
\text { through the } \\
\text { programme. }\end{array}$ \\
\hline $\begin{array}{l}\text { Participant } 8 \\
\text { (NGO) }\end{array}$ & $\begin{array}{l}\text { Director } \\
\text { Advancing } \\
\text { life and } \\
\text { regenerating } \\
\text { motherland } \\
\text { (ALARM) }\end{array}$ & $\begin{array}{l}\text { Works on forest } \\
\text { conservation } \\
\text { Focuses on } \\
\text { green growth, } \\
\text { social equity and } \\
\text { environmental } \\
\text { justice }\end{array}$ & $\begin{array}{l}\text { A member of } \\
\text { one technical } \\
\text { working group }\end{array}$ & $\begin{array}{l}\text {-See it is difficult } \\
\text { for the Government } \\
\text { of Myanmar to } \\
\text { implement REDD+ } \\
\text { because of poor } \\
\text { coordination among } \\
\text { government } \\
\text { departments, } \\
\text { knowledge, capacity } \\
\text { and infrastructure } \\
\text { about the } \\
\text { programme, and } \\
\text { transparency issue } \\
\text {-But also expect the } \\
\text { implementation of } \\
\text { REDD+ will } \\
\text { discuss land } \\
\text { sharing, resource } \\
\text { sharing and revenue } \\
\text { sharing (benefit- } \\
\text { sharing) }\end{array}$ \\
\hline Participant 9 & Villager, & Local community in & Attends & A tool \\
\hline
\end{tabular}

${ }^{19}$ During the interview with the participant from RECOFTC, her organization gave "Grassroots Capacity Building for REDD+" to forest-dependent communities in 2013 in three different regions: Sagaing Region, Bago Region and Ayeyarwaddy Region in Myanmar funded by the Norad. The criteria for choosing these regions are a high population of ethnic minorities (indigenous peoples), the level of their dependence on forests nearby and areas of forest covered (Participant 7). One of my case studies is in the Bago Region. 


\begin{tabular}{|c|c|c|c|c|}
\hline $\begin{array}{l}\text { Participant } \\
\text { Code Name }\end{array}$ & $\begin{array}{l}\text { Role } \\
\text { Organization }\end{array}$ & $\begin{array}{l}\text { Nature of } \\
\text { organization }\end{array}$ & Role in REDD+ & $\begin{array}{l}\text { Expectation of } \\
\text { REDD }+{ }^{16}\end{array}$ \\
\hline $\begin{array}{l}\text { (Local } \\
\text { community) }\end{array}$ & Bago & $\begin{array}{l}\text { Hpa-Do village, } \\
\text { Kyauktaga } \\
\text { Township, Bago } \\
\text { Region }\end{array}$ & $\begin{array}{l}\text { REDD+ related } \\
\text { trainings, } \\
\text { workshops } \\
\text { invited by } \\
\text { NGOs }\end{array}$ & $\begin{array}{l}\text {-to solve land rights } \\
\text { and land ownership } \\
\text { for indigenous } \\
\text { peoples and forest- } \\
\text { dependent } \\
\text { communities } \\
\text {-to empower local } \\
\text { communities' } \\
\text { participation in } \\
\text { forest governance }\end{array}$ \\
\hline $\begin{array}{l}\text { Participant } 10 \\
\text { (Academic- } \\
\text { Associate } \\
\text { Professor) }\end{array}$ & $\begin{array}{l}\text { Department } \\
\text { of } \\
\text { Agricultural } \\
\text { Economics, } \\
\text { Yezin } \\
\text { Agricultural } \\
\text { University }\end{array}$ & $\begin{array}{l}\text { The only institution } \\
\text { of higher learning } \\
\text { in agriculture }\end{array}$ & $\begin{array}{l}\text { Attends } \\
\text { REDD+ related } \\
\text { meetings, } \\
\text { trainings, } \\
\text { workshops } \\
\text { invited by } \\
\text { GOM and } \\
\text { NGOs }\end{array}$ & $\begin{array}{l}\text {-Harmonisation } \\
\text { across different } \\
\text { sectors for the } \\
\text { country's } \\
\text { development } \\
\text {-Sustainable } \\
\text { economic } \\
\text { development }\end{array}$ \\
\hline $\begin{array}{l}\text { Participant } 11 \\
\text { (Researcher) }\end{array}$ & $\begin{array}{l}\text { Center for } \\
\text { Economic } \\
\text { and Social } \\
\text { Development } \\
\text { (CESD) }\end{array}$ & $\begin{array}{l}\text { "An independent } \\
\text { and non-political } \\
\text { think tank } \\
\text { supporting } \\
\text { evidence-based } \\
\text { policy making that } \\
\text { mobilizes } \\
\text { development of } \\
\text { resources, both } \\
\text { domestic and } \\
\text { international, to } \\
\text { bring Myanmar to } \\
\text { her rightful place in } \\
\text { the region and the } \\
\text { world"20 }\end{array}$ & $\begin{array}{l}\text { Is not directly } \\
\text { involved in } \\
\text { REDD+ }\end{array}$ & $\begin{array}{l}\text {-To have a high } \\
\text { level political } \\
\text { commitment to } \\
\text { implement REDD+ } \\
\text {-Not to depend too } \\
\text { much on the donors } \\
\text {-To integrate } \\
\text { REDD+ into policy } \\
\text { making of non- } \\
\text { forestry sectors such } \\
\text { as agriculture, } \\
\text { energy etc. to } \\
\text { protect the natural } \\
\text { environment }\end{array}$ \\
\hline
\end{tabular}

Some participants in the government institutions I interviewed perceived REDD + as a necessary tool to reduce deforestation and forest degradation while others were not fully aware of the REDD+ programme. Regarding the government sector's involvement in the REDD+ initiative, some of the staff I interviewed were assigned to work for the REDD+ programme in addition to their main tasks in their government departments; and Participant 5 from the local government stated that:

We are assigned to participate in the REDD+ workshops and meetings; and sometimes we are asked for assistance by the Forest Research Institute (Participant 5).

${ }^{20} \mathrm{CESD}$ https://myanmarcesd.org/about/ 
Among the government institutions, the Ministry of Energy and Electricity (MOEE) ${ }^{21}$ is one of the key stakeholders which should be included in the implementation of REDD+. The participation of this agency is important because it is one of the key line ministries, with many responsibilities relevant around implementing REDD+ such as considering forest and land uses for energy production (UN-REDD, 2013). Also the energy sector is one of the primary sectors in mitigating GHG emissions in Myanmar (MOECAF, 2015a). However, there was little or no awareness of REDD + at that ministry. The Director General of the Energy Department was not aware of the REDD+ programme and not sure who is currently involved in the REDD+ initiative:

I am not aware of the REDD+ programme and not sure who are currently involved from this ministry... But our department is doing the best to tackle climate issues such as reducing carbon emissions from the energy sector related activities (Participant 3).

From interviews and observations, I learned some staff had heard about the programme through the REDD+ awareness training workshops run by the FRI and UN-REDD. However, the REDD+ awareness training is unlikely to be effective because the government staff members have their main tasks which require them full-time and the $\mathrm{REDD}+$ programme is not a main priority. One participant ${ }^{22}$ stated that " $[\mathrm{t}]$ rainings and workshops given by UN-REDD and FRI are not effective." It seems that the FD and the FRI are the only agencies which hold the full sense of ownership and commitment to implement the REDD+ initiative.

Concerning technical assistance and moving the process forward, UN-REDD expected to develop the 'National REDD+ Strategy' by November 2017 through consultation with different stakeholders in each state and region. This was to develop 'an action plan' for a pilot implementation phase which would be the second stage of the REDD+

\footnotetext{
${ }^{21}$ Based on the preliminary study of the stakeholder mapping developed by the UN-REDD and the Forest Department, the Ministry of Energy (MOE) (which is now a part of MOEE) is one of the related ministries in REDD+ implementation. The UN-REDD and FRI/FD also invited this agency to meetings and inter-ministerial workshop.

${ }^{22}$ Due to the ethical obligation, the participant is not mentioned in this thesis although my participant is willing to be mentioned by the role or the name of the organization. The critique/ point made by this participant is an important piece of information for the Government of Myanmar (GOM) to be aware of and improve their performance on the REDD+ Readiness Stage. However, Myanmar has been under the military rule and such openness or critique to the government may harm to my participant. One must be cautious in talking about the current situation in Myanmar although the country's current political situation is moving forward to a democratic one.
} 
implementation after the readiness phase. This has not been achieved and the strategy is currently still in the draft stage ${ }^{23}$.

Unlike the government agencies, the Non-Government Organizations (RECOFTC and ALARM) I interviewed had a better understanding of the initiative. Specifically, The Center for People and Forests (RECOFTC) ${ }^{24}$ was involved in the REDD+ activities at the early stage because the organization saw that the objectives of REDD+ were aligned with the interests and focus of their organization. RECOFTC was established in 1987 and started a programme called "Grassroots Capacity Building for REDD+" in Myanmar in 2013 (Participant 7). "RECOFTC supports community forestry development and the empowerment of local people in managing forests in Asia and the Pacific. Its efforts are aimed at promoting sustainable forest management and providing for the needs of the more than one billion rural people in the region who depend on forest resources for their livelihoods" (Durst, Brown, Tacio, \& Ishikawa, 2005, p. ii). In the introduction of REDD+ to Myanmar, RECOFTC was funded by $\mathrm{Norad}^{25}$. It was asked to give capacity-building training (REDD+ awareness) in some REDD+ project demonstration areas to local or forest-dependent communities. But RECOFTC is no longer directly involved in the REDD+ readiness activities because they were only contracted to give REDD+ awareness trainings for a limited time period. Funding from Norad for this type of training has since run out. However, this organization participated in REDD+ activities and events such as training, workshops, and meetings to offer their opinions and suggestions. Although the RECOFTC is no longer involved as a main stakeholder, its contribution in the earliest stage highlighted how the Government of Myanmar initiated the programme, its engagement with the local communities and the importance of the forest-dependent communities.

Another organization involved in the programme is a local NGO called Advancing life and regenerating motherland (ALARM). The director of this organization explained that the government invited ALARM to become a member of one of the technical working groups. The vision of ALARM is "to transform the resilient society to adaptive climate

${ }^{23}$ Informal communication with the UN-REDD Programme Office in January, 2018.

${ }^{24}$ RECOFTC stands for Regional Community forestry Training Centre for Asia and the Pacific, but as the name is long, it is now called "The Centre for People and Forests" (Participant 7).

${ }^{25}$ Norad is Norwegian Agency for Development Cooperation which has supported civil society organizations (CSOs) contributing to REDD+ since 2009. https://www.norad.no/en/front/funding/climateand-forest-initiative-support-scheme/ 
change". It focuses on green growth, social equity and environmental justice (MyanmarAffairs, n.d.). ALARM is interested in the forestry sector and forest conservation, which was the main motivation for them to engage with the REDD+ programme.

The villagers who participated in my two cases studies in the Bago Region and Shan State, detailed in Chapter Three, believed that REDD+ is aligned with their traditional forest protection and conservation methods. Therefore, REDD + is seen by them as a similar way to conserve forests and livelihoods. The communities in Shan State had been experiencing climate change and unpredictable weather events for some time, with consequences such as having difficulty growing crops. As a result, they have become aware of the importance of forests and of protecting them. Based on my observation in Shan State, I saw community forestry areas where the government had integrated REDD + to those areas. The villagers in Pindaya Township, Shan State said they would like to keep the forests, not because of the incentives provided by the developed countries for saving trees, but because they were aware of global warming (Field notes, 26 July 2017).

Most of my participants thought that initiating REDD+ was a good way to mitigate climate change issues and a good tool to protect forests. Some participants saw implementing REDD + as necessary because it helps to protect and conserve forests from deforestation and forest degradation. It also promises to mitigate and tackle climate change issues. One participant from the local communities in the Bago Region stated that:

REDD+ is needed in Myanmar to prevent deforestation and forest degradation, and then to get sustainable forest management, to protect biodiversity loss, and ecosystems, and to mitigate climate change issues (Participant 9).

In addition, some believed that it could also give financial incentives for protecting forests:

... Implementing REDD+ initiative could give financial incentive through selling carbon credits. This initiative helps to save trees. But the commercial logging has been exploiting forests although it can also makes money. So, REDD+ is necessary to be implemented instead of chopping down the trees (Participant 10). 
Some of my participants from government agencies and local communities also hoped to get technical assistance for managing forests. However, based on my observations and a comment from one participant from the donor agency (Participant 6), there were people who lacked interest in the REDD+ initiative because they were not familiar with REDD + . He added that REDD + awareness-raising is important in implementing REDD + in general, and in REDD + readiness activities in particular. While lack of awareness seems to be an issue, those stakeholders who were aware of REDD+ were generally enthusiastic about it.

\subsubsection{Carbon and benefit sharing}

Some participants from the government, NGO and the community in Bago raised questions about benefit-sharing and carbon ownership. Myanmar is still in the early stages of developing a mechanism for sharing benefits gained from selling carbon. One of the participants from the Bago community argued that communities should gain benefits from carbon.

REDD + is also seen as carbon commodification. In relation to benefit-sharing through selling carbon-credits, communities deserve more benefits because they are the key stakeholders who live nearby the forest and who can really conserve and manage them. Moreover, the government has not yet announced that carbon credits are state-owned. Therefore, I recommend the government should carefully negotiate and calculate who should receive how much and why (Participant 9).

Participants believe that REDD+ can be beneficial because of benefit-sharing, developing a power balance among stakeholders, and strengthening all stakeholders' involvement. This would be achieved by giving incentives, being fully transparent and ensuring good governance at each level (i.e. at community, district, and national levels). Some expect REDD+ to provide solutions for local development and for improving livelihoods as they can get financing through the REDD+ programme.

Interestingly, the villagers in Pindaya Township, Shan State, where I conducted the participant observation, (Field notes, 26 July 2017) had not yet considered what benefits they would get and how to share benefits with the government or any other stakeholders who are involved in the community forestry areas integrated with REDD+.

REDD+ is a performance-based (result-based) payment mechanism and its core objective is carbon trading. One participant raised the argument that before result-based 
payments, there should be alternative livelihood options for rural communities who depend on the forest. She said that:

It is important to consider the existing livelihood situations of rural community. Shouldn't wait till the last stage (result-based payments). So, from the beginning of the initiative, the government should consider what alternative livelihood or opportunities will be offered to rural communities nearby project areas because it is impossible if the communities are restricted to access the forests (Participant 10).

Although carbon credits are regarded as a major benefit, others have suggested alternatives for REDD+. Moreover, what the implementing agencies have been experiencing is that it is too technical to monitor, report and verify the carbon credits and there are too few technicians and experts to review the existing policies in Myanmar (Participant 6).

\subsubsection{Beyond carbon benefits}

Beyond the core objective of carbon credits in REDD+, Participant 5 from the local government stated that Myanmar could establish a tourism-related sector from saving forests and promoting biodiversity. This would be an alternative way of perceiving REDD+. Myanmar's rich natural resources, biodiversity, and cultural heritage could attract tourists. However, the closed economy and political instability have been barriers to tourists visiting the country (Khanal \& Babar, 2007). Nevertheless, Myanmar's economy is opening up and the development of forest-based tourism or ecotourism ${ }^{26}$ is now possible; local communities could benefit from this.

Another participant from the government did not see any direct benefit to his organization but acknowledged that REDD+ implementation would be beneficial nationwide (Participant 4). He believed that REDD+ was a long-term programme and it should be implemented in a sustainable manner. He stated that REDD+ should be legalized (i.e. there should be a law to protect or to ensure that REDD+ implementation is sustainable.)

\footnotetext{
${ }^{26}$ Ecotourism is the term which combined with 'ecology' and 'tourism' (Mahbubul, Yasushi, \& Salma, 2010). "The Nature Conservancy adopts the definition articulated by the World Conservation Union (IUCN): "Environmentally responsible travel to natural areas, in order to enjoy and appreciate nature (and accompanying cultural features, both past and present) that promote conservation, have a low visitor impact and provide for beneficially active socio-economic involvement of local peoples." (The_Nature_Conservancy, n.d.)
} 
In general, the participants share a common expectation for the REDD+ initiative that will mitigate climate change through carbon sequestration and can reduce carbon emissions from deforestation and forest degradation. On a different note a participant mentioned that REDD+ can promote good forest management and good governance:

... to promote good governance through REDD+ implementation by strengthening all stakeholders' involvement; by giving incentives, by making full transparency and good governance at each level (at community, district and national levels) (Participant 5)

\subsubsection{Forest sustainability, forest income and cross-cutting sectors}

Some participants believe that the forests can be used for many purposes, including some that would not restrict villagers' access to them. They agree with saving trees and using the forests for the country's development, but also believe in using them to improve the livelihoods of forest-dependent communities. The associate professor from the University of Agriculture (Participant 10) stated that conserving natural resources is crucial for the country but using forest resources for the country's development should also be considered. Similarly, one participant from an NGO questioned whether selling carbon credits from saving trees has a greater benefit than commercial logging (Participant 8). Participant 7 from another NGO explained that it is necessary to use forest resources sustainably as well as protecting trees; for example, rural communities rely on the forests for their livelihood and they need wood for fuel for cooking and for fire during the cold season. Therefore, they suggest that the government carefully calculate costs and benefits for the country's development alongside the impacts on the forest-dependent communities in the initiative.

The associate professor from the University of Agriculture (Participant 10) expected REDD+ to help build harmony among different sectors (i.e. cross-cutting sectors for development of, for example, forestry, agriculture, mining, energy, or planning, are expected to collaborate and coordinate). She also predicted REDD+ would aid in some development issues like agricultural land expansion, irrigation, urbanization, building infrastructure, hydropower, and forest clearing. The academic highlighted that these development activities are drivers of deforestation and forest degradation. Therefore, each sector is required to coordinate harmoniously and like other participants, she hoped REDD + could help to protect forests and offer a healthy natural environment. 
The associate professor also emphasized that REDD+ does not deviate from existing forestry policies (e.g. Forest Law) and that its implementation could even strengthen forest protection. She highlighted that "[a]s REDD+ is a results-based payments initiative, the role of the rural communities who depend on the forests is critical to conserve them. Rural communities are expected to happily protect forests through their belief that their livelihoods will improve from the REDD+ programme." (Participant $10)$.

\subsubsection{Land tenure and other rights}

Myanmar was under a military regime for six decades and there have been political challenges, such as civil wars between ethnic armed groups and Myanmar military, which have created instability. Although rural communities are crucial for the conservation of forests, there are challenges to overcome in this country because of poor law enforcement and ethnic tensions. Land tenure and resource rights are at the forefront of the REDD+ initiative in Myanmar but the lack of law enforcement is one of the key challenges for the country. One participant stated that there are laws, regulations and policies to protect forests and biodiversity, but they are weak and there is ineffective enforcement.

There are laws, regulations and policies related to protecting forests, but they are not strong enough and also there is no law enforcement because of the country's current situation and political challenges such as civil war, unstable condition (Participant 5).

Despite having concerns about implementing REDD+, Participant 5 highlighted that REDD+ could provide a solution to local development. On a similar theme Participant 6 from a donor agency said that the rights of indigenous peoples will be protected, and their livelihoods will be ensured in the REDD+ safeguards. This is related to other participants' hopes for REDD+ that it will be a good mechanism for the natural environment, local communities, and people in rural areas.

Land rights for indigenous peoples will be ensured through safeguards. That is this will be included in the safeguards. Currently, Myanmar is in the process of designing safeguards through stakeholder consultation. In addition to land rights, the safeguards will also ensure food security and livelihood for the communities. Therefore REDD+ can provide more and better options for communities (Participant 6). 
According to Participant 9 in the Bago Region, people were evicted from their lands by the Myanmar $^{27}$ military in the 1970s. As discussed in Chapter One, after independence from the British in 1948 Myanmar experienced many years of civil war between ethnic groups and the Myanmar military. During the 1950s and 1960s, the highlands of Bago Yoma (the Bago Range) offered hideouts and, as a result, became battle zones (Woods, 2015). Moreover, teak forests were abundant in the area and were attractive as a source of revenue for the military, which indiscriminately cleared the forests. This led to deforestation and depopulation (Participant 9; Woods, 2015) and the teak forests became killing fields (Bryant, 2014). As a result, the local people lost their lands and community ${ }^{28}$ in the Bago Region. A participant I met expected REDD + to be a solution or a tool for land tenure and could help to determine land ownership through mapping. But he stressed that there will be challenges in identifying the owners of the land as ancestors have died, and it will be hard to recognize the exact locations of boundaries because the landscape changes (Participant 9).

One participant ${ }^{29}$ from the local community highlighted that in theory REDD + puts local people first (i.e. local people will be informed and consulted first). But in reality, according to his experience, he did not see the government have any prior consultation with the local community or indigenous peoples before implementing the REDD+ projects. He pointed out the importance of the government consulting with local communities and suggested the government know all issues in the area in advance, before REDD+ is initiated.

\subsubsection{Critiques on REDD+}

There are different perceptions among the stakeholders about the potential benefits of REDD+, but generally there is optimism. UN agencies and other foreign groups believe it can help control global deforestation and promote sustainable development. The Myanmar Government is enthusiastic about the prospects of carbon trading and commodification. And local communities hope it can help them to better manage the

\footnotetext{
${ }^{27}$ At that time, it was called the Burmese military.

${ }^{28}$ This community is in Pha Do Village, Kyauktaga Township, Bago Region.

${ }^{29}$ Due to the ethical obligation, the participant is not mentioned in this thesis although my participant is willing to be mentioned by the role or the name of the organization. The critique/ point made by this participant is an important piece of information for the Government of Myanmar (GOM) to be aware of and improve their performance on the REDD+ Readiness Stage. However Myanmar has been under the military rule and such openness or critique to the government may harm to my participant and one must be cautious in talking about the current situation in Myanmar although the country's political situation is moving forward to a democratic one.
} 
forests, perhaps in ways more beneficial to their livelihoods. Although the positive concepts of sustainability and the reduction of forest emissions underpin REDD+, there are critiques on its implementation.

Some criticisms of the government were expressed during my field research. According to Participant 8, the government has been giving false expectations and hopes to the local communities about the initiative and about carbon benefits. He added that the government convinced the local communities to establish community forest management (CFM) by making the villagers believe that CFM could improve their livelihoods and become a way of protecting forests. He further stated that the government had its own agenda of integrating REDD+ into CFM and did not clearly inform the local people, and that this shows the government's lack of transparency. According to this participant, the government emphasized its own agenda more than benefits for local people.

Similar criticisms of REDD+ in Myanmar made by another participant (anonymised) include " $[\mathrm{t}]$ he government was not transparent when introducing REDD + to the local communities". He further stated, "FRI is advocating for the villagers and communities to implement REDD+ by giving incentives such as efficient cooking stoves, by building schools, and by providing for teachers." He believed that with transparency, many people and communities would be enthusiastic about REDD+ without these incentives. These incentives, in his opinion, are designed to make REDD+ more popular amongst these communities but without promoting much awareness of the policy itself.

While optimism still greatly outweighs pessimism among most stakeholders, the latter is evident and centres mostly around transparency and communication. There even seems to be confusion amongst stakeholders from the same sectors, as indicated by the differing perceptions about REDD + . For example, some perceived that REDD+ implementation is for sustainable development (Participants 1 and 6) and some saw it as carbon commodification (Participants 1, 6, 9, and 11).

But although some stakeholders have different perspectives, they are still generally enthusiastic about the prospects of REDD+. Many believe that implementing it would create a platform that would address some of these communication issues, and ensure that REDD+ stakeholders would cooperate, have dialogue, and build trust. Some commented that good governance would be promoted through REDD+ implementation. 
I hope REDD+ can create a platform for the REDD+ stakeholders together to have dialogue and build trust among them. REDD+ can even support to have a dialogue for peace, conflict and land issues among them (Participant 5).

To conclude this section, the perceptions and motivations of my participants were shaped by their understandings of, and participation in, REDD+. Among the government departments, the Forest Department (FD) and the Forest Research Institute (FRI) are the most important implementing agencies from the public sector and they have a high level of interest for, and influence on, the REDD+ process. There is a limited understanding about the programme among line-ministries and local governments while the international and local NGOs have a better understanding and can play a key role in giving awareness trainings to people, with the collaboration of the central government. Among local communities, those who understand REDD+ are most concerned about land tenure and benefit-sharing. Overall the participants are optimistic about the programme and expect it can be a mechanism on which stakeholders can collaborate for sustainable forest management and to tackle climate change issues.

\subsection{Governance}

There are a number of governance issues related to the REDD+ initiative in Myanmar. Although REDD+ is seen as a mechanism to strengthen forest governance and support global conservation, several challenges were found during my fieldwork in relation to REDD+ readiness activities. The main challenges are governance issues such as clarity of governance arrangements, institutional coordination, stakeholder engagement, land tenure and inadequate understanding of the REDD+ initiative among stakeholders.

\subsubsection{Clarity of governance arrangements}

As mentioned in Chapter One about the status of REDD+ in Myanmar, the government is developing the REDD+ National Strategy for its implementation and this strategy will be piloted and tested in the next phase. A few REDD+ demonstration areas have been established in this readiness phase. However, regarding the governance arrangements and responsibilities of stakeholders involved in the programme, one participant raised a concern about the clarity of the REDD+ process. She said the REDD+ readiness activities are unclear to her and that there is no action plan for the readiness phase to guide which stakeholders take what responsibilities and how the readiness phase will be implemented. 
There is no action plan or any detailed activities for the REDD+ readiness phase. That's why it's hard for stakeholders (except the implementing agencies) to know what to do and why. I also suggested in the REDD+ meetings about this (Participant 10).

This is further commented on by Participant 6 from UN-REDD:

There is no action plan for this (REDD+ readiness) phase, however there is a work plan internally concerned with funding, etc. In the near future, there will be an action plan for the pilot implementation ${ }^{30}$ which is the second phase of the REDD+ programme.

Participant 11 from the academic sector commented on the same themes and said that he had not seen any clear policy concerning REDD+. Moreover, he stated that the government needs to have a sense of ownership, as this programme was driven and initiated by the UN. What this participant meant was that the programme would not be sustained if the government does not have a high level political will to implement it or if the government considers it to be a UN programme rather than its own. He added that he had seen a lot of unsustainable development aid projects driven by donor and international agencies. He also stressed that donors and development partners should enable the Myanmar Government to take ownership:

Donor-driven initiative is not sustainable. Therefore, there is a need to localize this global initiative and the government should have a sense of ownership.

With regard to policy, laws and regulations, Participant 11 continued:

There is a need to harmonise existing policies, laws and regulations because there could be issues at the implementing stage if there is no understanding of the obstacles.

Therefore, it is important to find out whether there is harmony between the existing policies and REDD+ requirements.

Participants' views on the need for harmony, cooperation and communication between all stakeholders have been voiced here. The following section will explore how stakeholders are involved in the programme.

\subsubsection{Multi-stakeholder coordination on REDD+}

This study found that there is poor coordination among cross-sectoral ministries in developing policies. This was highlighted by a participant from the academic sector

\footnotetext{
${ }^{30}$ Currently there are REDD+ demonstration (project) areas and full piloting will be in the next phase.
} 
who mentioned 'sector-wide policy vs nation-wide policy' and poor coordination among different sectors and government agencies:

Currently, each ministry has its own policy and there is no coordination with other ministries. For example, the Ministry of Agriculture has its policy to expand agricultural land area to increase production. In this case, clearing forests might be needed however; this ministry does not seem to care about deforestation or forest degradation. Therefore, coordination and negotiation between the forest department and the other sectors such as mining and hydropower are necessary. Therefore, the Government of Myanmar should consider a nation-wide policy (rather) than sector-wide policies (Participant 10).

Participant 5 from the government agency made an observation on the issue of REDD+ policies. He said that it is a national level policy initiative because it is centralised at the national level, and the regional and township level government offices have limited or no knowledge of the REDD+ programmes. Based on my observations and the information I was given in both the Bago Region and Shan State, only the FRI and FD from the national level had direct contact with the communities. The roles of the regional level forest departments were often unclear but these local government departments assist the national level government whenever they are asked to. Concerning stakeholder participation and engagement with the current REDD+ activities, one participant from a township level government highlighted that there is no consistency nor sound policy for regional or township level participation or engagement. He believed that having a sound policy and being consistent are necessary at all levels. As a result, there was a lack of a sense of ownership and strong coordination of, and commitment to, REDD+ among regional and local levels of government:

REDD+ is a national policy lead by the forest department (FD) and forest research institute (FRI). The regional and township level government offices have limited or no knowledge of the REDD+ programme and they don't know exactly what the national government does (Participant 5).

This shows poor information-sharing and weak coordination among government institutions. This poor coordination happened not only among line ministries (across sectors such as both forestry and non-forestry sector) but also occurred between the national and local levels. 


\subsubsection{Stakeholder participation and information flow}

This section will discuss stakeholder participation and information flow regarding the implementation of the REDD+ initiative in Myanmar. Among government agencies, regular meetings are being held and some government departments attend meetings and workshops and share information within and among departments.

However, this study found that there is a poor information-sharing system among government departments. For example, government staff from other line ministries invited to the meetings or workshops, attend the meetings but they do not have time to share the information with other staff in their departments. Therefore, there is limited awareness of the REDD+ programme throughout the government departments. I met with staff from the Departments of Mines, Energy and Agriculture. As mentioned above, government staff were assigned to attend the REDD+ programme meetings or workshops whenever their departments were invited. Although the line ministries committed to collaborating with FD and FRI, and some staff from these line ministries are members of the REDD+ taskforce or members of the technical working groups (TWGs), their involvement was limited because of time and workload constraints or because there was a limited number of staff who could fully participate in the REDD+ programme. Participant 1 from the government agency explained to me that the need for human resources and capacity is one of the challenges that Myanmar is facing for REDD+ implementation. As part of the awareness trainings, RECOFTC consulted with communities to identify any concerns and challenges which might occur when introducing REDD+. These were reported to the policy table to assist discussion at national level discussion and to help in the policy-making process.

Concerning stakeholders' participation and awareness of the REDD+ initiative, some of the participants gave their opinions on how to improve the current REDD+ readiness activities. All of them agreed that strong commitment by, and participation of, all stakeholders is crucial for an effective and successful REDD+ implementation. One participant from the government department stated that:

There should be clear roles and responsibilities among different stakeholders.

Moreover, it is important to reduce centralisation and it should be a bottom-up approach (Participant 5). 
Some NGOs and INGOs played a role in capacity building and awareness training in the communities concerned with forest conservation and REDD+ related information but they did not appear to collaborate with each other. The UN-REDD officer explained that the awareness-raising efforts have not yet been as effective as they need to be. He believed the national level government's understanding of the REDD + mechanism is adequate but it is hard to attain that same level of understanding throughout the whole country because of the geographical situation. He further highlighted the need for the ministries' understanding, interest, and capacity to implement the REDD+ mechanism (Participant 6). This participant emphasised the need for high level engagement which needs political will and commitment. He added that a bottom-up approach might not always work and the REDD+ implementation needed high level engagement and commitment. The government institutions have been under top-down administration and have been working under a chain of command which is a result of the military regime.

High level engagement, political will and commitment are needed but it is kind of lacking at this moment. It is essential because the information- sharing through high level government senior levels will be more effective among different ministries as well as different stakeholders (Participant 6).

Another participant spoke about providing awareness training as "giving awareness to different stakeholders; however, the effectiveness of giving awareness training depends on how much the implementing agencies can do" (Participant 10). She highlighted how transparency in the REDD+ programme is important and said that transparency is the key for the programme to succeed as it can help to build trust among different stakeholders (Participant 10).

Two of my participants emphasized the importance of transparency in REDD+ activities based on their academic perspective. One said that transparency is a key to successfully implementing REDD+. The other said that the government needs to be transparent in communicating with other stakeholders. They both stressed that transparency builds trust among stakeholders (Participants 10 and 11). Participant 11 continued that as there has been no trust for a long time under the military government, it is very important for all the actors involved in REDD+ to be transparent with each other. 
Concerning interaction among stakeholders, one participant from the government department recommended that national-level centralisation be decreased and said that it is essential to promote power-sharing and power balance among different government agencies and different government departments (Participant 5).

With regard to the need for private sector participation, some participants suggested that the private sector should be involved from the REDD+ readiness phase. The involvement of the private sector in the initial stage is essential because it is one of the stakeholders that accesses forest resources, such as in the timber industry. Moreover the private sector could play a role in funding (UN-REDD, 2013). One participant from the donor agency explained that the private sector is currently lacking concern or interest in REDD+ because the status and process of REDD+ is not yet directly linked to them. The participant from UN-REDD stated that the private sector is not fully aware of, or does not understand, REDD+; this participant stated that the private sector should be involved but there is no interest and no pressure on them to become involved in the programme at this moment.

It is also important to note the importance of local communities (forest-dependent communities) in protecting the forests as stressed by another participant. "It is important to be aware of the grassroots level" (Participant 7). One participant from the local government commented that local communities are important to the implementation of the REDD+ programme and argued that they should be included in decision-making processes. He further suggested that the roles of local communities should be increased as they are not key stakeholders in the decision-making process at this moment (Participant 5).

Some participants stressed the need for REDD+ awareness-raising for all the participants, including government agencies. Besides awareness of REDD+ activities, willingness, and commitment of all stakeholders to be involved in the REDD+ implementation is necessary. The participants from UN-REDD, from the academic sector, and from the local community have the same view on the importance of stakeholders' commitment in implementing REDD+. Participant 9 from the local community in the Bago Region stated that "REDD+ requires all stakeholders - both government and people - have a will to implement REDD+". Similarly, one participant 
from the academic sector stressed that inclusiveness is important in the initial stage of the programme.

Different stakeholders' engagement is needed to seek different perspectives and points of view. There should also be a better and stronger engagement with issues-based civil society organizations which can help to communicate with the public more effectively (Participant 11).

In addition, one participant highlighted the important role of the implementing agencies such as the Forest Department (FD) and the Forest Research Institute (FRI). She stressed that all the staff from FD and FRI, such as rangers and extension agents at the township level, must fully understand REDD+. She stressed her opinion on the information-sharing and implementation policy and stated that activities such as workshops and training by the implementing agencies are inadequate as they are not nationwide. Although key stakeholders are invited to the workshops and trainings, there are still few representatives from the other key government agencies and these actors still need an understanding of the REDD+ initiative. If they have a better understanding of the programme, it will be easier to implement it (Participant 10).

Participant 6 from the UN-REDD office explained that there are (i) technical working groups (TWGs), (ii) CSOs, NGOs, indigenous peoples related to forests, and (iii) stakeholder networks to share the information. However, he stressed that he was not yet satisfied about information sharing. In regard to interaction with other stakeholders, he said his organization (UN-REDD) did not hold a coordination role and did not have direct interaction with other donors, or NGOs. According to him, only FD/ FRI took a coordination role and had direct interaction with other stakeholders. Although the UNREDD office plays important roles such as organizing trainings and workshops for stakeholders in the REDD+ implementation process, this shows that there is a lack of effective communication among stakeholders.

Most of my participants believed that all relevant stakeholders should be involved in the readiness activities as this would enable more multi-stakeholder consultation, would make REDD+ more effective in building trust among stakeholders, and increase transparency. 


\subsection{Synopsis}

The findings from this study show how stakeholders in Myanmar see the REDD+ initiative. The study found optimism and enthusiasm about REDD+ implementation although people perceive and understand the initiative differently. But there are issues relating to the implementation of the readiness phase such as stakeholders' awareness, poor coordination among stakeholders, especially between government agencies. In addition, the study found there is a general issue of transparency in relation to institutional arrangements, land tenure, and collaboration among stakeholders. The next chapter will discuss how my findings are linked to the existing literature on REDD+ implementation. 


\section{Chapter Five: Discussion}

This chapter discusses research findings in relation to existing literature introduced in Chapter Two. The overarching theme that characterised this research was that there is a lack of transparency in relation to REDD+ readiness activities in Myanmar. This chapter will discuss how a lack of transparency has led to uncertainty about land tenure, about who will and should lead REDD+, and about what the funding and life span of REDD + will be. In addition it highlights some potential challenges such as designing benefit-sharing mechanisms, particularly in the projects where REDD+ is being integrated into CFM areas. In order to analyse how different stakeholders perceive REDD+, and how Myanmar is planning to implement the initiative, the study also looks at its governance. The chapter also touches on how my research findings contribute to existing research about REDD+.

\subsection{Storylines around REDD+/ Perception of REDD+ implementation}

This section looks at the perceptions and implementation of REDD+ projects. Social science literature about REDD+ shows that implementing it has been a controversial issue around the world, with a range of perspectives and implications for forest governance and climate change mitigation (Bastakoti \& Davidsen, 2017; Bushley \& Khatri, 2011; Phelps et al., 2012). Bushley and Khatri (2011) claim that REDD+ is a mechanism to enhance forest governance and promote environmental conservation through reducing emissions from deforestation and forest degradation. Other scholars argue that safeguards in REDD+ have the potential to bring both climate change mitigation and benefits for biodiversity conservation (Bastakoti \& Davidsen, 2017; McDermott et al., 2012; Peterson, Gallagher, Huberman, \& Mulder, 2012; van der Hoff et al., 2015; Vijge, 2015). Bushley and Khatri (2011); Bluffstone et al. (2013) and Van der Hoff et al., (2015) highlight that REDD+ is a cost-effective policy which creates financial rewards through trading carbon and reducing deforestation and forest degradation.

However other researchers are critical of REDD+ and argue that it could destabilise forest governance, strengthen government control over forests and weaken community autonomy to manage forest resources (Bastakoti \& Davidsen, 2017; Lander, Bello, Brand, Bullard, \& Mueller, 2009; Phelps et al., 2010; Poudel et al., 2014). A study in Indonesia also resulted in censure of REDD+. It found that some stakeholders see the 
programme as a false solution to combat climate change issues and one that brings a neoliberal idea of carbon marketization (Astuti \& McGregor, 2015). Others see REDD+ as both an opportunity and a challenge in climate change mitigation and this makes it a growing debate at both international and national levels (Bastakoti \& Davidsen, 2017; Bushley \& Khatri, 2011; Phelps et al., 2010) as well as in political and scholarly circles (Vijge, 2015).

The literature shows that different actors involved in REDD+ see it differently. Individuals' perspectives and interests, as well as their roles in participating in its implementation and their level of understanding about the initiative, have given rise to different discourses. International and local actors are optimistic about implementing it as a means to reduce carbon emissions (Bluffstone et al., 2013). From interviews and participant observations, I found that there is enthusiasm for implementing REDD + in Myanmar. Most importantly, the government, the Forest Department (FD) and the Forest Research Institute (FRI), are committed to addressing climate change issues and to implementing REDD+ as a mechanism to reduce carbon emissions.

\subsubsection{Carbon vs Non-carbon storylines}

The carbon storyline considers forest carbon as a tradable commodity on international markets (van der Hoff et al., 2015). The storyline also includes that it is a form of sustainable development and ecological and biodiversity conservation that addressed climate change issues (Astuti \& McGregor, 2015; Boer, 2013; Gupta, Lövbrand, Turnhout, \& Vijge, 2012; McGregor et al., 2014). For the purpose of my discussion, I will look at the way my participants' perceptions of REDD+ parallel these storylines. Some of the people I interviewed see REDD+ as a tool to reduce carbon emissions, increase carbon sequestration and gain financial benefit from enhancing carbon stock (Participants 1, 5, 6, 9 and 11). Other participants see that REDD+ could bring sustainable economic development (Participants 1 and 10). One study in Brazil highlights that some actors are concerned about carbon commodification, specifically about the fair distribution of both financial and non-financial benefits among stakeholders (van der Hoff et al., 2015); despite the concerns which arose from the Brazilian, the consensus among stakeholders about carbon commodification is generally positive (van der Hoff et al., 2015). This parallels the optimism and concerns of many participants in this study. 
The community I met in the Bago Region see the forests as spiritual, holding cultural values and valuable economic resources for their livelihoods. Therefore, they are willing to conserve the forests regardless of financial incentives. They believe that REDD + is aligned with what they value about the forests (Participant 9). Existing literature also highlights that REDD+ becomes a choice for the forestry community because the local traditional knowledge of forest use and conservation can be connected with the latest scientific methods for the sustainable use of forests when communities are encouraged to participate in the REDD+ process (Scheba \& Scheba, 2017).

The participants who mentioned REDD + as a carbon storyline were those who had a better understanding of the programme. The study found different levels of understanding of REDD+ among the forest-dependent communities. The community in the Bago Region had more understanding of the programme than those in Shan State. While a participant from the Bago Region spoke about the right of carbon ownership in addition to better forest management, the local communities in the other case study (Shan State) simply saw REDD+ as a climate change mitigation tool to protect the forests (Field notes, 27 July 2017). This highlights that forest communities are interacting with the programme in different ways based on their level of understanding of the programme. This adds to the argument from some participants that raising awareness around all aspects of REDD+ is important.

\subsubsection{Effective climate change policy (win-win storyline)?}

REDD + is seen as a crucial and cost-effective climate change mitigation instrument because it promises to decrease the cost of reducing emissions and increase forest values (Bluffstone et al., 2013; Bushley \& Khatri, 2011; van der Hoff et al., 2015). The literature shows that some developing countries (such as in Cameroon and Indonesia) are interested in implementing REDD+ because it is perceived as a mechanism to reduce the rate of deforestation and forest degradation through promoting sustainable forest management (Somorin et al., 2014).

Some actors in my country see REDD+ as an effective climate change policy. They believe that REDD+ is needed in Myanmar to reduce carbon emissions from deforestation and forest degradation and see that it could help to protect the remaining forests. They also perceive REDD+ as helping to achieve sustainable forest management, protecting biodiversity loss, conserving ecosystems, and mitigating 
climate change issues (Participants 5, 9 and 10). Participant 9 from the forest community in the Bago Region stated that "REDD+ is needed in Myanmar to prevent deforestation and forest degradation, to manage forests sustainably, to protect biodiversity loss, and ecosystem, and to mitigate climate change issues."

In addition, Participants 5, 6, and 10 see REDD+ can also offer financial incentives for protecting forests and result-based payments from implementing REDD + can benefit local communities. This is similar to what existing literature highlights (Bastakoti \& Davidsen, 2017). According to Participant 5, "The result-based payment through REDD+ can provide financial benefits and solutions to local communities' development and livelihoods". Participant 10 similarly stated that "implementing a REDD+ initiative could give financial incentives through selling carbon credits. This initiative helps to save trees". Participant 6 added that "In addition to land rights, the safeguards will also address and ensure food security and livelihood for the communities. Therefore REDD+ can provide more and better options for communities".

As mentioned above, some participants in Myanmar are optimistic about REDD+ and they believe it can be a tool to solve the issues of land tenure and improve their livelihoods (Participant 5, 6 and 10). This is similar to perceptions in other developing countries such as in Nepal (Bastakoti \& Davidsen, 2017). Some scholars agree and claim that the implementation of a REDD+ initiative will provide financial benefits to the developing countries and help indigenous communities with alternative livelihoods (Bastakoti \& Davidsen, 2017; Pearse, 2011; Vijge, 2015). The study in Nepal by Bastakoti and Davidsen (2017) reported that some actors from a conservation organization believed REDD+ would bring benefits to local communities. However others in civil society argued that the financial compensation received from the initiative does not fulfil the need for alternative livelihoods for the forest-dependent communities, as local people are still concerned about their rights to access forests for their livelihoods.

The literature shows that forest-dependent communities are important and play an essential role in the REDD+ implementation (Atela et al., 2016; Gebara, 2013; Leggett $\&$ Lovell, 2012). The fragile livelihoods of communities relying on the forests is highlighted by participant 10 from the community in the Bago Region. This participant remarked that it is important to provide alternative livelihoods or opportunities to access 
the forests for the forest-dependent rural communities near the REDD+ project areas before the result-based payments are made. According to what I learned from the Forest Research Institute (FRI), the Government of Myanmar has been providing alternative livelihood options to the villagers near the REDD+ projects such as energy efficient cooking stoves, tree planting, and vocational training in making handicrafts using bamboo (Participant 1; Participant Observation).

However, it is unclear who the forest-dependent communities are in the context of the REDD + project in the Bago Region. This reserved forest ${ }^{31}$ has been closed to people from nearby villages. The government official from the Forest Research Institute explained that the project in that area is aiming to be registered with the UNFCCC for the purpose of entering the carbon market. In this case, it is unclear who will benefit from the resulting carbon credits. This project raised questions about benefit-sharing because the project is on the State's land and it appeared all the carbon benefit would go to the government. Further research is required into how the benefit-sharing will work.

This is similar to existing research which describes the compensation given to communities in Tanzania as a result of losing forest access because of a REDD+ project (Svarstad \& Benjaminsen, 2017). As compensation the project provided some livelihood elements: "improved cooking stoves, sustainable charcoal production, energy-efficient brick production and tree planting” (Svarstad \& Benjaminsen, 2017, p. 484). However, it is questionable as to whether these compensate for the actual loss of forest access or contribute to the sustainability of livelihoods. Svarstad and Benjaminsen (2017) highlight the fact that the forest-dependent communities are likely to pay the cost of conservation as an impact of REDD+ as the compensation provided to the communities does not cover the negative effects on livelihoods from the closure of the forest due to the project. Benefiting from carbon payments in Myanmar was commented on by Participant 8 who said that Myanmar still has a long way to go before it sees the benefit of carbon credits and closing forest access to the forest-dependent communities is not a solution to protect deforestation and forest degradation. On the same theme Participants 7 and 8 stated that forests are valuable resources and these resources should also be used for multiple purposes. If forest-dependent communities no longer have access to forests for their livelihood and they are not provided any

${ }^{31}$ Explained in Chapter Three (Section 3.2.2 Case study approach). 
alternative livelihoods options, there will be more costs than benefits to communities (Participants 7, 8, and 10).

Some scholars claim that REDD+ has brought some new benefits and opportunities for land tenure security and tenure rights, but there are still challenges (Larson et al., 2013). If there is uncertainty about land ownership, or conflict about land boundary mapping, more powerful actors could gain unequal benefits from REDD+ payments (Larson et al., 2013; Leggett \& Lovell, 2012). Therefore, some scholars highlight that there is a safeguards storyline in REDD+ which focuses on non-carbon forest values such as biodiversity conservation, security of land tenure, and social equity (McDermott et al., 2012; Vijge, 2015). According to Participant 5, REDD+ could provide a platform to discuss land issues. Furthermore, Participant 6 explained that land rights for indigenous peoples would be addressed and ensured through that safeguard. However, land rights are an extremely contentious issue in Myanmar.

These complexities demonstrate that REDD+ is not a simple case of win-win. There are potential costs to forest-dependent communities, and until land tenure and benefitsharing arrangements are worked out and communicated in Myanmar, it will be hard to properly calculate who is gaining, and what exactly they are gaining. Effective governance is needed to address these issues.

\subsection{Governance of REDD+ in Myanmar}

Looking at the institutional structures and arrangements helps to understand how REDD+ functions in Myanmar. My research explored and analysed how different stakeholders perceive the REDD+ initiative, and therefore the governance of REDD+ comes into the equation. My case studies in the Bago Region and Shan State revealed some issues around this. The first was in the Bago Region and related to institutional arrangements; my results show that there is a lack of, or poor coordination among the actors. Different stakeholders have different influences on the REDD+ initiative based on their level of participation and their roles. In the second case study in Shan State I found a transparency issue in relation to integrating REDD+ into community forest management (CFM) as the knowledge of local communities about REDD+ is limited.

\subsubsection{Case study 1: Participant observation in Bago Region}

Although my intention to meet people from the local communities close to a REDD+ project underpinned my study, this did not happen because there was a lack of 
transparent information about who was involved in the programme, who the key stakeholders were, and which forest-dependent communities were in the project. Another difficulty was whether the trainings and workshops offered by the government or non-governmental organizations reached the right stakeholders or the right people. These difficulties emphasize the need for clear and transparent networks among key implementing agencies. The next REDD + aspect to be examined is land tenure and the communities that depend on land.

\subsubsection{Land tenure and forest-dependent communities}

Communities of people have relied on forests for their livelihoods for centuries. Although REDD + projects purport to support these communities by conserving the forests, who owns them and who has the right to access them, is proving problematic in several countries (Bolin \& Tassa, 2012; Leggett \& Lovell, 2012), including Myanmar.

The REDD+ project in the Bago Region is located in a reserved forest which is stateowned and where access is strongly restricted. One of the reasons for the restrictions is that ownership rights are very controversial. Land classification and tenure have been major issues in Myanmar (MONREC \& UN-REDD, 2017). Based on what I learned from Participant 9 who lived near that area, there should not be any village in that area as ownership of that land is not clear. Even so there are people settled in and around the area. It is questionable which local communities depend on the forest for their livelihoods in this specific area. To further confuse matters, there are people living in this restricted state-owned forest area. The scope of my study did not cover why and how they are there. However, I learned from some local villagers in Hpa Do village, and from observing the surrounding areas that these people also grow some crops in that area. Although they admit it is illegal, they believe they have rights to live there as they have lived there for some time. As stated in Chapter Four, the military forced all the villagers to leave their lands in the 1970s (Bryant, 2014; Woods, 2015) and since then, land ownership has not been clear (Participant 9). This is similar to the context in Tanzania: The Isabe and Salanga forests have been closed for a REDD+ project, but, in theory, these forests had been closed since the mid- $20^{\text {th }}$ century. However, the villagers have been accessing the forests despite this (Svarstad \& Benjaminsen, 2017). It is ambitious to hope to solve land issues in Myanmar through this REDD+ programme because of the complexity of tenure. 
Land issues are not the only challenges in implementing the REDD+ programme. In the REDD+ readiness phase, identifying the drivers of deforestation and forest degradation is one of the requirements for implementing countries. Among drivers, shifting cultivation is one of the main elements that accounts for forest changes and degradation (Htun, 2009; UN-REDD, 2013). It is important to discuss, when looking at the REDD+ scheme, whether the swidden cultivation method is actually responsible for deforestation and degradation, and how stakeholders see this. While there is evidence that slash and burn practices have wiped out some forest cover in Myanmar (Htun, 2009), the community in the Bago Region tend to believe that the practice is not a main cause of environmental degradation (Participant 9). Participant 9 explained that the tradition of shifting cultivation has meant that no group settled in one place permanently and this has led to land tenure issues, as it is difficult for any one group to claim ownership. Not only does shifting cultivation make REDD+ implementation more difficult, it also further compounds already existing land tenure issues.

Local community members and local government officials agree that illegal logging and illegal hunting of elephants are also problems in the region (Participant 5, and Participant 9). Illegal logging has been one of the main issues in the Bago Range (Bago Yoma) for both the government and the local communities. In April 2014, the government introduced a policy to restrict and, in some cases, ban logging for 10 years in that area to preserve forests (EIA, 2016; Mclaughlin \& Tun, 2016). There is uncertainty as to whether the trucks and logging are legal or illegal because the government has given permits to private companies to restore and replant teak and bamboo in the reserved (restricted) area for periods ranging from three to 10 years (Field notes, July 2017). Whatever the reasons for logging, there should be a mechanism to check whether the companies are logging from permitted lands or from state-owned forests. What this says is that clear and strong policies, as well as a monitoring system for forest resource uses, are desperately needed. According to Participant 4, illegal logging could be a challenge for implementing REDD+ if strong policies and enforcement are not in place. Participant 5 from the local government explained that there is a shortage of staff to enforce policies and that it could be dangerous, life-threatening even, to arrest the illegal loggers because staff from the forest department are not able to defend themselves. These are general challenges for the township level government staff to deal with. 


\subsubsection{Consultation and institutional coordination}

Consultation with the forest communities and coordination with the relevant institutions are crucial. Research has found that a lack of, or poor consultation with local communities and landowners has significant negative implications for REDD+ implementation (Leggett \& Lovell, 2012). Regarding consultation with local communities prior to implementing REDD+ in Myanmar, Participant 7 from the NGO sector explained that there were consultations with local communities before implementing REDD+ projects in some regions. Consultations with local communities were supposed to help policy people discern any concerns or challenges raised at the local level. However the community I met in the Bago Region stated that they were ignored at the early stage of REDD+ establishment (Participant 9). Although free, prior, informed, and consent (FPIC) is required for REDD+ implementation, it seemed to him that the government started the project without consultation with the local community. This indicates that consultation did not occur in all the regions where REDD+ has been implemented. This was backed up by observations and conversations with villagers I met, who felt that the government did not consult with the people before the project was implemented (Participant 9; and Participant observation). At the same time, other participants commented that there was consultation.

Although different government departments acknowledged the importance of local level participation, there was poor coordination among these departments. If the local government does not have a sense of ownership or does not consider this initiative as a core responsibility, there may be challenges in its implementation in the future.

Participant 1 from the national level explained that the government introduced REDD+ demonstration project areas at sub-national levels and from there, the township level projects would be extended to the district and national levels. The ultimate goal is to reach national level REDD+ implementation. Sub-national level projects are likely to be part of the national REDD+ implementation. This suggests that both the national level and sub-national level governments should be responsible and accountable for the initiative. Local governments should take some responsibility and make a commitment to the programme. However, as Participant 5 explained, the township level forest department sees REDD+ as the national level government's project.

Generally, poor coordination between Myanmar's national and sub-national levels of government makes it difficult to determine how much the various governments are 
committed to REDD+. However in my research areas, it was clear that the national government currently holds full responsibility and commitment to REDD+ projects while commitment from local government is barely seen.

Participant 9 from the local community stated that more awareness of REDD+ programmes is needed not just amongst the public but in government institutions as well. It is important that government departments are fully knowledgeable about REDD + as the government is a key stakeholder in the implementation process. This high level commitment is essential to sustain programme implementation. He further stated that the roles of local governments are important because they are geographically closer to the local communities. However they need experience and knowledge of the initiative, willingness to collaborate with the public and a strong will to implement the REDD+ programme. Bushley and Khatri (2011) argue that REDD+ implementation cannot be successful on a national scale without proper consultation with local institutions and local communities.

\subsubsection{Case study 2: Participant observation in Shan State}

I conducted the study in the Bago Region to find out how local communities understand REDD+ implementation and how they feel about it. However the village (Hpa Do) I visited was not close to the REDD+ demonstration area. As a result, I added another field visit to Pindaya, Shan State in July, 2017 where I met the local forest-dependent communities living close to the REDD+ demonstration area. The specific areas of the study were three villages, namely Pwe Hla, Shar Pyar and Nan Kone. In these areas, REDD+ is being integrated into the community forest management (CFM) area.

My observation in Shan State was surprising as some of the local people and the staff from the township level forest department there thought I was coming to conduct research on community forestry. This of course was not the case as I was there to observe the REDD+ demonstration project areas. Some of the villagers were aware of REDD+ but they had limited understanding of the programme and were not clear about the relationship between CFM and REDD+. They thought the CFM land was land they had full authority to manage; they were not fully aware that these CFM areas were integrated with the REDD+ project (Field notes, 27 July 2017). At this early stage, I observed that everyone on these CFM project areas - so called "REDD+ demonstration 
areas" ${ }^{, 32}$ were positive about current efforts to protect forests. However, the lack of information shared with local people about the nature of the relationship between CFM project areas and REDD+ demonstration areas suggests that proper communication, a key component of the readiness phase, has not been accomplished.

Evidence suggests that these problems around transparency and the integration of CFM and REDD+ extend beyond Shan State. Participant 8 from a non-government organization, and a member of one of the REDD+ technical working groups (TWGs), explained his experiences working with the government to implement REDD+ pilot projects. He said that the government was giving false promises to the local communities and spoke of the lack of transparency around the initiative. He gave the example of one REDD+ project site in another region where my research was not conducted and said that the government asked the local communities to apply for community forest management, integrated REDD + to those areas, and named them "REDD+ demonstration project sites".

Although the communities appeared to understand the system of CFM and seemed to be willing to protect the forests, the government did not engage the villagers based around those goals; instead it tried to convince the villagers that REDD+ would bring them financial benefits. This participant stressed that the government is giving false promises to the public even when the local community's opinions are consistent with the aims of REDD+. He explained that sometimes, the government even attempts to gain agreement through promises that are inconsistent with the aims of the programme. Finally, he commented that there is still uncertainty about carbon credits and questioned whether enhancing the carbon stock is a solution to local development.

\subsubsection{Integrating REDD+ into CFM}

REDD+ and CFM both share the common objective of sustainable forest management and these two systems can be integrated. In some developing countries, land tenure is poorly defined. In addition, some scholars emphasize that the ownership of carbon should be clarified whether or not land tenure is well defined. This is a vital issue for indigenous peoples and local communities who contribute to managing forests and reducing carbon emissions (Larson et al., 2013; Leggett \& Lovell, 2012). In Nepal,

${ }^{32} \mathrm{REDD}+$ demonstration areas is a term used by the government as the areas are not yet enough to be called as a "REDD+ Project Site". 
there is still uncertainty and a lack of clarity about carbon rights although REDD + is considered successful and integrated into their community forest management system (Ojha et al., 2013).

Existing research shows that REDD+ may lead to recentralisation of forest management by governments in developing countries and weaken the structure of community forest management (Newton et al., 2015; Rowe, 2015). According to Community Forestry Instructions (1995) in Myanmar, rural communities have legal rights to full participation in forest management and conservation. Despite this it is not clear how much participation the local or forest-dependent communities have in the REDD+ mechanism, particularly in the areas where the two systems have been integrated. Without integrating the two systems, these communities may have full rights to receive benefits from CFM where they administer it. But how a benefit-sharing mechanism is designed among stakeholders and who has control over its management and administration when REDD+ is integrated into CFM is still not a clear process. Moreover uneven power relations among stakeholders has been an issue in some developing countries and more powerful actors, such as local elites and central governments, could gain uneven benefits. Leggett and Lovell (2012) argue that this is an issue in Papua New Guinea (PNG). This is also an issue in Nepal (Atela et al., 2016). For the communities in Pindaya (Shan State), the ultimate aim of establishing community forestry is to conserve the forest and to mitigate climate change issues. Recently, they have faced environmental challenges such as drought and unpredictable weather events which have made their lives and their livelihoods difficult. For example, they rely on rain to grow seasonal crops but they were not able to farm as consistently as in the past because of drought.

However, it is interesting to note that the villagers I observed were not fully aware of what REDD+ is and how they can benefit from the programme. Based on my observations, I found that they are not aware of the integration of REDD+ into their community forestry land and there may be a potential conflict between these two programmes. The literature shows that combining these programmes has both benefits and challenges (Newton et al., 2015). In Pindaya, in terms of sharing benefits, I asked one village head whether and how these benefits will be distributed between the government and the communities who look after the trees. He answered that he is not 
sure as the trees were just planted. The trees will take time to grow and the local stakeholders are a long way from receiving added benefits from the land as a result of REDD+.

The situation in 'Pindaya' demonstrates the extent to which REDD+ in Myanmar is not transparent. In particular it raises questions about programme integration with existing livelihoods and forest management, and the funding they received from the GOM and the international donor agency (further explanation about the donor is mentioned in the next paragraph). Furthermore, the villagers I met are not really aware of what REDD+ is although they have heard about it and they have been receiving some training from the REDD+ programme. The government offered the village heads a trip to Nepal to learn how forests have been managed and protected through community forestry and REDD + . They observed the forest management system in Nepal, particularly community forest management, and how REDD+ is being implemented there. But they did not seem to understand what REDD+ is and how it works (Field notes, 27 July 2017). For the potential leaders in the implementation process to better understand the projects, further awareness about the programme and more transparency is needed. The central government is responsible for ensuring stakeholders understand the programme and for coordinating among actors.

In Nepal, REDD+ enabled the government to centralise forest governance and restricted the involvement of civil society organizations and communities. Furthermore, the autonomy and voices of local communities have been weakened because of technical challenges related to measuring forest carbon (Bastakoti \& Davidsen, 2017). As a result, the benefit-sharing mechanism is not clearly defined and local communities have not received the financial benefits that they are entitled to (Gebara, 2013; Pearse, 2011). This is not an issue in Myanmar at present as it is in its earliest stage of combining the two mechanisms for managing forests, and the local communities in these three villages have just introduced CFM. One village head I met in Pindaya, Shan State did not even seem to understand what kind of benefits the local communities would receive from the land they will be looking after. Through participant observations, my study found there needs to be a greater understanding of REDD + and a more open and transparent dialogue among stakeholders in this early stage of the REDD+ implementation to avoid unnecessary misunderstandings. 
Existing literature has highlighted the importance of addressing how the design of benefit-sharing mechanisms will work, who is entitled to them, and who has autonomy to manage the projects when two systems are combined (Poudel et al., 2014). There is no specific study on the benefit-sharing mechanism within the context of REDD+ integration into CFM or CCF. Participant 9 from the Bago Region stated that communities deserve more benefits because they are the key stakeholders - they live near the forest and they can actually manage it and he recommended that the government carefully design and negotiate with the different stakeholders and calculate who should receive how much and why. But in Myanmar, the government has not yet announced whether the carbon credits are state-owned. Moreover Bluffstone et al. (2013) argue that if REDD+ is not properly designed and implemented, the initiative could destabilise the functions of CFM. Funding is also an issue and unless this is sustained, the future of both projects is in jeopardy.

\subsubsection{Sustainability of funding}

Funding may not be sustainable for the projects in Myanmar after 2018. Relying on donor financing can create challenges for recipient countries to sustain projects. In terms of funding, Participant 1 raised financial concerns as one of the challenges associated with REDD+ implementation. He explained that sustainability of funding, the need for human capital and technical capacities, are the main problems the forest department has been struggling with to implement REDD + . These challenges are common across developing countries engaged in REDD+.

Newton et al. (2015) highlight concerns related to integrating the two systems such as designing equitable benefit-sharing, the sustainability of funding for REDD+ pilot projects and whether or not these pilots will be claimed at the national level of the REDD+ project. Although this is not an issue in Myanmar at the moment, it is possible that the country might experience it in the near future. As mentioned above, ICIMOD funding to REDD+ projects in Myanmar brought some benefits to the local communities. However, there are uncertainties about what the government and communities will do when these ICIMOD funded REDD+ pilot projects in Shan State end in 2018. Therefore, it is possible that communities could see the projects as false

promises or false solutions to tackle climate change and forest conservation (Newton et al., 2015). Ojha et al. (2013) argue that project-based or donor-led initiatives are not 
well engaged with the local context although REDD+ should be a locally owned initiative. Participant 11 raised the similar issue of donor-driven projects and sustainability. According to him, donors and development partners should allow the government to have a sense of ownership because donor-driven initiatives are not sustained, based on his experiences. He stressed that this global initiative should be localized.

\subsection{Synopsis}

This chapter discussed how Myanmar is implementing REDD+, how different actors understand it, and what governance issues have arisen from its implementation. The REDD+ project site in the Bago Region raised several issues, including land ownership, illegal logging, identifying affected communities and the level and duration of their participation in the programme. The willingness of local governments to participate was explored and their level of understanding of the programme was found to be entirely inadequate. This presents potential barriers to the effective and sustainable implementation of REDD+ as it is necessary to involve all stakeholders, from local villagers and governments to provincial and central governments. Participant observation in Pindaya, in Shan State, also suggested a lack of knowledge and transparency which could lead to unclear and questionable benefit-sharing between CFM and REDD+. The onus is on the central government to ensure clear lines of communication and transparency of information. If these are not instituted, the success of REDD+ in Myanmar is in doubt. 


\section{Chapter Six: Conclusion}

This thesis analyses the readiness phase of REDD+ in Myanmar, how stakeholders perceive the programme and how it is being implemented. This research is pertinent because of three main reasons. Firstly, issues of deforestation and carbon depletion urgently need to be addressed, and Myanmar's changing political and economic situation means that environmental protection practices in the country will be shaped in the coming years. Secondly, limited literature exists about current environmental and human rights protection and poverty reduction efforts in Myanmar, and likewise few studies worldwide have focused on the readiness phase of REDD+ implementation. Thirdly, research that is independent of the UN, the Myanmar government, or NGO affiliation, especially focused on the perceptions of the various stakeholders in the REDD+ implementation process, can help all groups better evaluate the potential success of REDD+ in Myanmar and the adjustments needed to ensure that success. I was fortunate to have been granted access to various project locations, which would have been difficult to achieve without command of the Myanmar language. My shared ethnicity with certain participants may have helped me gain confidence that I might not otherwise have attained. This means I was in a unique position to be able to conduct this research in Myanmar, and future research might be more difficult to achieve. This research finds that a stronger emphasis on transparency during the readiness phase is essential for the potential success of REDD+, and while this conclusion has been reached specifically in the context of Myanmar, it might be applicable in other countries implementing REDD+.

\subsection{Summary of findings}

The findings demonstrate that there is an optimism among stakeholders about its implementation. However, based on individuals' level of understanding of the programme, their participation and interest shaped what they expected from the programme. The findings also suggested that there is poor coordination among actors and a lack of both knowledge of the programme and transparency about how it is working. This could lead to a misunderstanding among actors and could also lead to issues in benefit-sharing in the future. The central government is a key agency to ensure the information about REDD+ is delivered to the relevant stakeholders and coordinated among stakeholders to ensure the participation of each stakeholder is adequate in the REDD+ implementation process (Somorin et al., 2014). However this study shows that 
there is weak coordination among stakeholders and there is inadequate participation by some key stakeholders, including local governments and the private sector.

This research focused on two main case studies in Myanmar. Each had different approaches to, and purposes for, introducing REDD + . One was carbon commodification and the other, integration into an existing CFM. But one common feature of both is that they lacked adequate involvement from the local government. A similar conclusion was reached by Nuesiri (2017) in Nigeria where they examined local participation in the process of designing national level REDD+ implementation. Nuesiri (2017) concluded that the programme suffered from lack of participation from the local government and that the safeguards built into the REDD+ plan did not do enough to stimulate involvement from local governments. This study finds that the central government and particularly the Forest Research Institute (FRI) is more knowledgeable about the REDD+ programme than any other Government agency or stakeholders. Since safeguards have not proven to be effective and since the central government in Myanmar holds so much power over REDD+ implementation, it is the responsibility of the central government to try to stimulate local government involvement in the REDD+ programme.

At the moment, safeguards are being designed in Myanmar by the technical working group (TWG) on stakeholder engagement and safeguards through consultation with related actors. The hope is that these safeguards will stimulate involvement from the local governments and communities, which would in turn mitigate the effects of lack of transparency from the national Government. But, like in Nigeria, these safeguards might not do enough.

Regarding stakeholders' perceptions of the REDD+ programme, I discussed how my participants saw the programme based on three storylines: the safeguards storyline, the co-benefits storyline, and the carbon storyline. While the central government aimed for sustainable development and carbon credits from the initiative, the local government expected the programme to bring a platform for empowering local participation in forest governance. Many stakeholders are optimistic about the potential benefits of REDD+ implementation in Myanmar, not only for combating and controlling environmental degradation, but also as a mechanism for improving livelihoods and human rights. But in the context of the country's rapid democratisation of the political landscape -- since 
the contexts in which this policy is being adopted are so rapidly changing -- how the next stage(s) of REDD+ implementation will actually unfold is still very much unclear. Developing safeguards is an essential element of ensuring that the REDD+ mechanisms in Myanmar do indeed serve to mitigate deforestation and forest degradation as well as enhance communities' livelihoods and promote human rights. But REDD+ policymakers in Myanmar should anticipate that such safeguards will not do enough for the programme to reach its aims and should develop other means of increasing local government participation in the implementation process.

\subsection{Limitations of this research}

Access to information was the main limitation to my research. Because of the lack of transparency in Myanmar generally, it was challenging for me to identify the key stakeholders and the demonstration areas in the country. Also, the 12-month time frame of this research, combined with being based in Aotearoa New Zealand, meant that I was limited in my ability to build relationships with research participants. For both case studies, I conducted participant observations to supplement the semi-structured interviews I conducted.

\subsection{Future research}

From Case Study One in the Bago Region, a few questions came up which need further investigation. One of these is whether people near the project area are indigenous peoples or a forest-dependent community. This will help to determine more specifically their roles regarding such matters as whose responsibility it is to manage the forest, who has access to forest resources, what benefits the community will get from the project, and how the government will share those benefits. These issues need to be addressed before the last stage of REDD+ implementation because that is when the payment-based mechanism becomes active. Further study should focus on the benefits and impacts of this initiative for the natural environment, for people in forest-dependent communities, and for indigenous peoples.

In Case Study Two, in Shan State, further research is needed about how REDD+ and CFM are integrated. I tried to get clarification from the national government with regard to the situation of integrating REDD+ into CFM and if the government sees any potential conflict between these two programmes. However the government wasn't forthcoming with this information. A few specific questions emerged: (i) what will 
happen after 30 years when the CFM land grant expires? (ii) who will benefit from the CFM land?; (iii) how will the benefit-sharing mechanism work?; (iv) what are the opportunities and the potential conflicts between the two systems.

These are important issues related to the success of REDD+ in Myanmar, both in terms of the environmental success of the programme -its impact on forest degradation and deforestation mitigation - and in terms of the social benefits it has brought to people in Myanmar. But the current lack of transparency means that measuring success is going to be very difficult to do. This has serious implications for the viability of the resultsbased payment mechanism in the final stage of the REDD+ programme. 


\section{Reference list}

Agrawal, A., Chhatre, A., \& Hardin, R. (2008). Changing Governance of the World's Forests. Science, 320(5882), 1460-1462.

Alcamo, J. (2003). Ecosystems and human well-being: a framework for assessment. Washington, D.C., USA: Island Press.

Allan, J. I., \& Dauvergne, P. (2013). The Global South in Environmental Negotiations: the politics of coalitions in redd+. Third World Quarterly, 34(8), 1307-1322. doi:10.1080/01436597.2013.831536

Angelsen, A., Gierløff, C. W., Beltrán, A. M., \& den Elzen, M. (2014). REDD credits in a global carbon market: Options and impacts: Nordic Council of Ministers.

Astuti, R., \& McGregor, A. (2015). Governing carbon, transforming forest politics: A case study of Indonesia's REDD+ Task Force. Asia Pacific Viewpoint, 56(1), 21-36. doi:10.1111/apv.12087

Astuti, R., \& McGregor, A. (2016). Indigenous land claims or green grabs? Inclusions and exclusions within forest carbon politics in Indonesia. The Journal of Peasant Studies, 44(2), 445-466. doi:10.1080/03066150.2016.1197908

Atela, J. O., Quinn, C. H., Minang, P. A., Duguma, L. A., \& Houdet, J. A. (2016). Implementing REDD+ at the national level: Stakeholder engagement and policy coherences between REDD+ rules and Kenya's sectoral policies. Forest Policy and Economics, 65, 37-46. doi:10.1016/j.forpol.2016.01.003

Bastakoti, R., \& Davidsen, C. (2017). Framing REDD+ at National Level: Actors and Discourse around Nepal's Policy Debate. Forests, 8(3), 57. doi:10.3390/f8030057

Berg, L. D. (2009). Discourse Analysis A2 - Kitchin, Rob. In N. Thrift (Ed.), International Encyclopedia of Human Geography (pp. 215-221). Oxford: Elsevier.

Bernard, H. R. (2000). Social research methods : qualitative and quantitative approaches / $\mathrm{H}$. Russell Bernard: Thousand Oaks, Calif. London : Sage Publications.

Bluffstone, R., Robinson, E., \& Guthiga, P. (2013). REDD+and community-controlled forests in low-income countries: Any hope for a linkage? Ecological Economics, 87(Supplement C), 43-52. doi:https://doi.org/10.1016/j.ecolecon.2012.12.004

Boer, H. (2013). Governing Ecosystem Carbon. Global Environmental Politics, 13(4), 123-143. doi:10.1162/GLEP_a_00201

Bolin, A., \& Tassa, D. T. (2012). Exploring Climate Justice for Forest Communities Engaging in REDD+: Experiences from Tanzania. Forum for Development Studies, 39(1), 5-29. doi:10.1080/08039410.2011.635380

Bryant, R. L. (2014). The social lives of forests: past, present, and future of woodland resurgence (S. B. Hecht, K. D. Morrison, \& C. Padoch Eds.). Chicago, USA: University of Chicago Press.

Bushley, B. R., \& Khatri, D. (2011). REDD+: reversing, reinforcing or reconfiguring decentralized forest governance in Nepal. Retrieved from Nepal: http://forestaction.org/app/webroot/vendor/tinymce/editor/plugins/filemanager/files/Dis 
cussion $\% 20$ Paper $\% 20$ Series $\% 2011.3 \% 20$ Final $\% 20$ Draft $\% 209 \% 20$ september, $\% 202011$ .pdf

Cadman, T., \& Maraseni, T. (2012). The governance of REDD+: an institutional analysis in the Asia Pacific region and beyond. Journal of Environmental Planning and Management, 55(5), 617-635. doi:10.1080/09640568.2011.619851

Chacko, E. (2004). Positionality and Praxis: Fieldwork Experiences in Rural India. Singapore Journal of Tropical Geography, 25(1), 51-63. doi:10.1111/j.0129-7619.2004.00172.x

Chhatre, A., \& Agrawal, A. (2009). Trade-Offs and Synergies between Carbon Storage and Livelihood Benefits from Forest Commons. Proceedings of the National Academy of Sciences of the United States of America, 106(42), 17667-17670.

Chhatre, A., Lakhanpal, S., Larson, A. M., Nelson, F., Ojha, H., \& Rao, J. (2012). Social safeguards and co-benefits in REDD+: a review of the adjacent possible. Current Opinion in Environmental Sustainability, 4(6), 654-660.

doi:https://doi.org/10.1016/j.cosust.2012.08.006

Cohen, D., \& Crabtree, B. (2006). Qualitative Research Guidelines Project. from Robert Wood Johnson Foundation http://www.qualres.org/

Corbera, E., \& Schroeder, H. (2011). Governing and implementing REDD+. Environmental Science \& Policy, 14(2), 89-99. doi:10.1016/j.envsci.2010.11.002

Cotula, L., \& Mayers, J. (2009). Tenure in REDD: Start-point or afterthought? In Natural Resource. London: International Institute for Environment and Development (IIED).

Creswell, J. W. (2014). Research design : qualitative, quantitative, and mixed method approaches / John W. Creswell (Fourth edition, international student edition.. ed.): Los Angeles, Calif. : SAGE.

Cronkleton, P., Bray, D. B., \& Medina, G. (2011). Community Forest Management and the Emergence of Multi-Scale Governance Institutions: Lessons for REDD+ Development from Mexico, Brazil and Bolivia. Forests, 2(2), 451.

Davis, C., Daviet, F., Nakhooda, S., \& Thuault, A. (2009). A review of 25 readiness plan idea notes from the World Bank Forest Carbon Partnership Facility. Retrieved from http://pdf.wri.org/world_bank_readiness_review.pdf

Denzin, N. K., \& Lincoln, Y. S. (2011). The Sage Handbook of Qualitative Research / edited by Norman K. Denzin, Yvonna S. Lincoln (4th ed.). Thousand Oaks : Sage.

Durst, P. B., Brown, C., Tacio, H. D., \& Ishikawa, M. (2005). In Search of Excellence: Exemplary Forest Management in Asia and the Pacific. Bangkok, Thailand : Food and Agriculture Organization of the United Nations Regional Office for Asia and the Pacific : Regional Community Forestry Training Center for Asia and the Pacific.

EIA. (2016). Myanmar logging ban a major step to forest sector reform [Press release]. Retrieved from https://eia-international.org/myanmar-logging-ban-major-step-forest$\underline{\text { reform }}$

Erazo, J. S. (2016). REDD: Development Opportunity or Neoliberal Threat? Indigenous Organizations Take Opposing Views. NACLA Report on the Americas, 46(1), 55-60. doi:10.1080/10714839.2013.11722013 
Evans, D., Gruba, P., \& Zobel, J. (2014). How to Write a Better Thesis (3rd ed.). Cham, Switzerland: Springer International Publishing AG.

FAO. (2010). Global Forest Resources Assessment 2010 (Main report) (163). Retrieved from Rome: Italy: http://www.fao.org/docrep/013/i1757e/i1757e.pdf

Flowerdew, R., \& Martin, D. (2005). In R. Flowerdew \& D. Martin (Eds.), Methods in Human Geography : a Guide for Students Doing a Research Project (2nd ed.). Harlow, England. New York : Prentice Hall.

Gebara, M. F. (2013). Importance of local participation in achieving equity in benefit-sharing mechanisms for REDD+: a case study from the Juma Sustainable Development Reserve. International Journal of the Commons, 7(2).

Gergen, K., \& Gergen, M. (2008). Social Constructionism. In L. M. Given (Ed.), The SAGE Encyclopedia of Qualitative Research Methods (Vol. 2, pp. 816-820): Thousand Oaks, Calif.: Sage Publications.

Gerring, J. (2007). Case study research : principles and practices / John Gerring. New York: New York : Cambridge University Press.

GOM. (2012). Framework for Economic and Social Reforms. Myanmar: Governmet of Myanmar (GOM) Retrieved from file://C:/Users/thihanth/Downloads/english.pdf.

Guba, E. G. (1990). The Paradigm dialog / edited by Egon G. Guba. In. Newbury Park, Calif.: Newbury Park, Calif. : Sage Publications.

Gupta, A., Lövbrand, E., Turnhout, E., \& Vijge, M. J. (2012). In pursuit of carbon accountability: the politics of REDD+ measuring, reporting and verification systems. Current Opinion in Environmental Sustainability, 4(6), 726-731. doi:https://doi.org/10.1016/j.cosust.2012.10.004

Hajer, M., \& Versteeg, W. (2005). A decade of discourse analysis of environmental politics: Achievements, challenges, perspectives. Journal of Environmental Policy \& Planning, 7(3), 175-184. doi:10.1080/15239080500339646

Hall, S. (2001). Foucault: Power, knowledge and discourse. In W. Margaret, S. Taylor, \& S. J. Yates (Eds.), Discourse theory and practice: A reader (1 ed., pp. 72-81). London: SAGE: The Open University.

Hay, I. (2010). Qualitative Research Methods in Human Geography / [edited by] Iain Hay (3rd ed.). New York : Oxford University Press.

Hlaing, E. E. S., \& Inoue, M. (2013). Factors affecting participation of user group members: comparative studies on two types of community forestry in the Dry Zone, Myanmar. Journal of Forest Research, 18(1), 60-72. doi:10.1007/s10310-011-0328-8

Holliday, I. (2010). Ethnicity and Democratization in Myanmar. Asian Journal of Political Science, 18(2), 111-128. doi:10.1080/02185377.2010.492975

Holstein, J., \& Gubrium, J. (2011). The Constructionist Analytics of Interpretive Practice. In Y. L. N. Denzin. (Ed.), The SAGE Handbook of Qualitative Research (4 ed., pp. 341-358). California: Thousand Oaks: SAGE. 
Htun, K. (2009). Myanmar forestry outlook study. Asia-Pacific forestry sector outlook study II. Retrieved from Food and Agriculture Organization of the United Nations, Regional Office for Asia the Pacific, Bangkok: http://www.fao.org/docrep/014/am252e/am252e00.pdf

Humphreys, D. (2008). The politics of 'Avoided Deforestation': historical context and contemporary issues. The International Forestry Review, 10(3), 433-442.

Imperatives, S. (1987). Our Common Future: Report of the World Commission on Environment and Development. Retrieved from http://www.un-documents.net/our-commonfuture.pdf

Jolliffe, K. (2014). Ethnic Conflict and Social Services in Myanmar's Contested Regions. Retrieved from Myanmar: The Asia Foundation: https://asiafoundation.org/resources/pdfs/MMEthnicConflictandSocialServices.pdf

Lander, E., Bello, W., Brand, U., Bullard, N., \& Mueller, T. (2009). Contours of Climate Justice Ideas for Shaping New Climate and Energy Politics. Retrieved from Uppsala, Sweden:

Larson, A. M., Brockhaus, M., Sunderlin, W. D., Duchelle, A., Babon, A., Dokken, T., . . . Huynh, T.-B. (2013). Land tenure and REDD+: The good, the bad and the ugly. Global Environmental Change, 23(3), 678-689. doi:10.1016/j.gloenvcha.2013.02.014

Leggett, M., \& Lovell, H. (2012). Community perceptions of REDD+: a case study from Papua New Guinea. Climate Policy, 12(1), 115-134. doi:10.1080/14693062.2011.579317

Limb, M., \& Dwyer, C. (2001). Qualitative methodologies for geographers : issues and debates / edited by Melanie Limb and Claire Dwyer. London: London : Arnold.

MacDicken, K., Jonsson, Ö., Piña, L., Maulo, S., Contessa, V., Adikari, Y., . . . D’Annunzio, R. (2016). Global Forest Resources Assessment 2015: how are the world's forests changing? (9251092834). Retrieved from Rome: https://www.uncclearn.org/sites/default/files/inventory/a-i4793e.pdf

McDermott, C. L., Coad, L., Helfgott, A., \& Schroeder, H. (2012). Operationalizing social safeguards in REDD+: actors, interests and ideas. Environmental Science \& Policy, 21, 63-72. doi:10.1016/j.envsci.2012.02.007

McDermott, C. L., Levin, K., \& Cashore, B. (2011). Building the Forest-Climate Bandwagon: REDD + and the Logic of Problem Amelioration. Global Environmental Politics, 11(3), 85-103.

McGregor, A., Weaver, S., Challies, E., Howson, P., Astuti, R., \& Haalboom, B. (2014). Practical critique: Bridging the gap between critical and practice-oriented REDD+ research communities. Asia Pacific Viewpoint, 55(3), 277-291. doi:10.1111/apv.12064

Mclaughlin, T., \& Tun, A. H. (2016). Myanmar bans lucrative logging in bid to preserve forests. Retrieved 20 January 2018, from https://www.reuters.com/article/us-myanmareconomy-logging/myanmar-bans-lucrative-logging-in-bid-to-preserve-forestsidUSKCN0XP1JT

MOECAF. (2014). REDD+ in Myanmar. Retrieved 22 January 2018, from http://reddmyanmar.blogspot.co.nz/2014/01/redd-in-myanmar.html 
MOECAF. (2015a). Myanmar's Intended Nationally Determined Contribution - INDC. Myanmar: Ministry of Environmental Conservation and Forestry (MOECAF).

MOECAF. (2015b). Stakeholder Engagement and REDD+ Implementation Experiences in Myanmar. Myanmar: Ministry of Environmental Conservation and Forestry (MOECAF).

MONREC, \& UN-REDD. (2017). REDD+ Strategy for Myanmar (Draft). Forest Department (Forest Reserach Institute). Ministry of Natural Resources and Environmental Conservation. Myanmar.

MONREC, \& UN-REDD. (n.d.). Summary of the REDD+ knowledge management and communication strategy. In. Myanmar: Ministry of Natural Resources and Environmental Conservation (MONREC).

MyanmarAffairs. (n.d.). ALARM. Retrieved 20 January 2018, from http://myanmaraffairs.com/?q=content/alarm

Newton, P., Schaap, B., Fournier, M., Cornwall, M., Rosenbach, D. W., DeBoer, J., . . . Agrawal, A. (2015). Community forest management and REDD+. Forest Policy and Economics, 56, 27-37. doi:10.1016/j.forpol.2015.03.008

Nuesiri, E. (2017). Feigning Democracy: Performing Representation in the UN-REDD Funded Nigeria-REDD Programme. Conservation and Society, 15(4), 384-399. doi:10.4103/cs.cs_16_106

Ojha, H. R., Khatri, D., Shrestha, K. K., Bushley, B., \& Sharma, N. (2013). Carbon, community and governance: is Nepal getting ready for REDD+? Forests, Trees and Livelihoods, 22(4), 216-229. doi:10.1080/14728028.2013.856166

Okoh, A. I. S. (2015). Greenhouse Gas Reduction Schemes and the Re-Colonization of Nature in Africa. Journal of Good Governance and Sustainable Development in Africa (JGGSDA), 2(4).

Parker, C., Cranford, M., Roe, S., \& Manandhar, U. (2013). REDD+ prospects in LDCs. Retrieved from https://ldcclimate.files.wordpress.com/2014/05/updated-redd-ldcpaper_final.pdf

Pearse, R. (2011). Mapping REDD in the Asia-Pacific: Governance, marketisation and contention. Browser Download This Paper.

Peterson, A. L., Gallagher, L. A., Huberman, D., \& Mulder, I. (2012). Seeing REDD: Reducing Emissions and Conserving Biodiversity by Avoiding Deforestation. Journal of Sustainable Forestry, 31(1-2), 29-58. doi:10.1080/10549811.2011.565710

Phelps, J., Friess, D. A., \& Webb, E. L. (2012). Win-win REDD+ approaches belie carbonbiodiversity trade-offs. Biological Conservation, 154, 53-60. doi:https://doi.org/10.1016/j.biocon.2011.12.031

Phelps, J., Webb, E. L., \& Agrawal, A. (2010). Land use. Does REDD+ threaten to recentralize forest governance? Science, 328(5976), 312-313. doi:10.1126/science.1187774

Poudel, M., Thwaites, R., Race, D., \& Dahal, G. R. (2014). REDD+ and Community Forestry: Implications for Local Communities and Forest Management- a Case Study from Nepal. International Forestry Review, 16(1), 39-54. doi:10.1505/146554814811031251 
Prakash, A. (2013). The economic transition in Myanmar: towards inclusive, people centered and sustainable economic growth. ERIA Policy Brief(2013-03).

Rowe, E. W. (2015). Locating international REDD+ power relations: Debating forests and trees in international climate negotiations. Geoforum, 66, 64-74.

doi:10.1016/j.geoforum.2015.09.008

Scheba, A., \& Scheba, S. (2017). REDD+ as 'inclusive' neoliberal conservation: the case of Lindi, Tanzania. Journal of Eastern African Studies, 11(3), 526-548. doi:10.1080/17531055.2017.1357102

Scheyvens, H., Scheyvens, R., \& Nowak, B. (2014). Personal Issues. In R. Scheyvens (Ed.), Development Fieldwork: A Practical Guide (2 ed., pp. 125-140). London: London SAGE Publications Ltd.

Scheyvens, R., Storey, D., \& ProQuest. (2003). Development Fieldwork : a Practical Guide / edited by Regina Scheyvens and Donovan Storey (2 ed.). London, United Kingdom: Sage Publications Ltd.

Seymour, F. (2017). Results-Based Payments to Reduce Deforestation. Retrieved 30 January 2018, from https://www.cgdev.org/blog/results-based-payments-reduce-deforestation

Singh, P. P. (2008). Exploring biodiversity and climate change benefits of community-based forest management. Global Environmental Change, 18(3), 468-478. doi:https://doi.org/10.1016/j.gloenvcha.2008.04.006

Somorin, O. A., Visseren-Hamakers, I. J., Arts, B., Sonwa, D. J., \& Tiani, A.-M. (2014). REDD+ policy strategy in Cameroon: Actors, institutions and governance. Environmental Science \& Policy, 35, 87-97. doi:10.1016/j.envsci.2013.02.004

Stern, N. (2008). The economics of climate change. American Economic Review, 98(2), 1-37.

Sultana, F. (2007). Reflexivity, positionality and participatory ethics: Negotiating fieldwork dilemmas in international research. ACME: An International E-Journal for Critical Geographies, 6(3), 374-385.

Sunderlin, W., Larson, A., \& Cronkleton, P. (2009). Forest tenure rights and REDD+: From inertia to policy solutions. In Realizing REDD+: National Strategy and Policy Options (A. Angelsen Ed.): CIFOR: Bogor, Indonesia.

Sunderlin, W., Larson, A., Duchelle, A., Resosudarmo, I. A. P., Huynh, T. B., Awono, A., \& Dokken, T. (2014). How are REDD+ Proponents Addressing Tenure Problems? Evidence from Brazil, Cameroon, Tanzania, Indonesia, and Vietnam. World Development, 55, 37-52. doi:https://doi.org/10.1016/j.worlddev.2013.01.013

Svarstad, H., \& Benjaminsen, T. A. (2017). Nothing succeeds like success narratives: a case of conservation and development in the time of REDD. Journal of Eastern African Studies, 11(3), 482-505. doi:10.1080/17531055.2017.1356622

the_REDD_desk. (6 April 2016). What is REDD+? Retrieved 19 March 2017, from http://theredddesk.org/what-redd

the_REDD_desk. (n.d.). Safeguards and co-benefits. Retrieved 17 March 2017, from https://theredddesk.org/theme/safeguards-and-co-benefits 
Thomas, G. (2013). How to Do Your Research Project : A Guide for Students in Education and Applied Social Sciences (2nd ed.). London, United Kingdom: Sage Publications Ltd.

UN-REDD. (2011). UN REDD Programme Strategy 2011-2015. Retrieved from UN-REDD (FAO, UNDP, UNEP), Washington DC:

https://www.iisd.org/pdf/2011/redd_programme_strategy_2011_2015_en.pdf

UN-REDD. (2013). Myanmar REDD+ Readiness Roadmap. Myanmar Retrieved from http://www.burmalibrary.org/docs18/Myanmar_REDD+Roadmap-2013.pdf.

UN-REDD. (2016). Fact Sheet: About REDD+. In. Geneva, Switzerland: UN-REDD Programme.

UNFCCC. (2014). Clean Development Mechanism (CDM). Retrieved 19 September 2017, from http://unfccc.int/kyoto_protocol/mechanisms/clean_development_mechanism/items/271 $\underline{\text { 8.php }}$

van der Hoff, R., Rajão, R., Leroy, P., \& Boezeman, D. (2015). The parallel materialization of REDD+ implementation discourses in Brazil. Forest Policy and Economics, 55, 37-45. doi:10.1016/j.forpol.2015.03.005

Vidal, J. (2009). Q\&A: Reducing Emissions from Deforestation and Degradation (Redd). Retrieved from https://www.theguardian.com/environment/2009/sep/24/redd-reducingemissions-from-deforestation

Vijge, M. J. (2015). Competing discourses on REDD+: Global debates versus the first Indian REDD+ project. Forest Policy and Economics, 56(Supplement C), 38-47. doi:https://doi.org/10.1016/j.forpol.2015.03.009

Watts, M. (2000). Political Ecology. In E. S. Sheppard \& T. J. Barnes (Eds.), A Companion to Economic Geography: Oxford, UK ; Malden, Mass., USA : Blackwell.

West, P. (2016, March 1 2016). Critical Political Ecology: From space and place to sovereignty. Retrieved from https:/www.youtube.com/watch?v=3aCkoB5d5gg

Woods, K. (2015). Intersections of land grabs and climate change mitigation strategies in Myanmar as a (post-) war state of conflict. MOSAIC Research Project. International Institute of Social Studies, The Hague, Netherlands.

WWF. (2017). Deforestation/ Threats. Retrieved 21 February 2017, from https://www.worldwildlife.org/threats/deforestation

Zainal, Z. (2007). Case study as a research method. Jurnal Kemanusiaan, 9(1), 1-6.

Zhu, X., Ravnkilde, L., De Lopez, T. T., \& Romero, M. E. Z. (2010). Pathways for implementing REDD+: Experiences from carbon markets and communities: Danmarks Tekniske Universitet, Ris ${ }^{-}$Nationallaboratoriet for BÊredygtig Energi.

Zomer, R. J., Trabucco, A., Bossio, D. A., \& Verchot, L. V. (2008). Climate change mitigation: A spatial analysis of global land suitability for clean development mechanism afforestation and reforestation. Agriculture, Ecosystems \& Environment, 126(1), 67-80. doi:https://doi.org/10.1016/j.agee.2008.01.014 


\section{Appendices}

Appendix 1: Human ethics approval

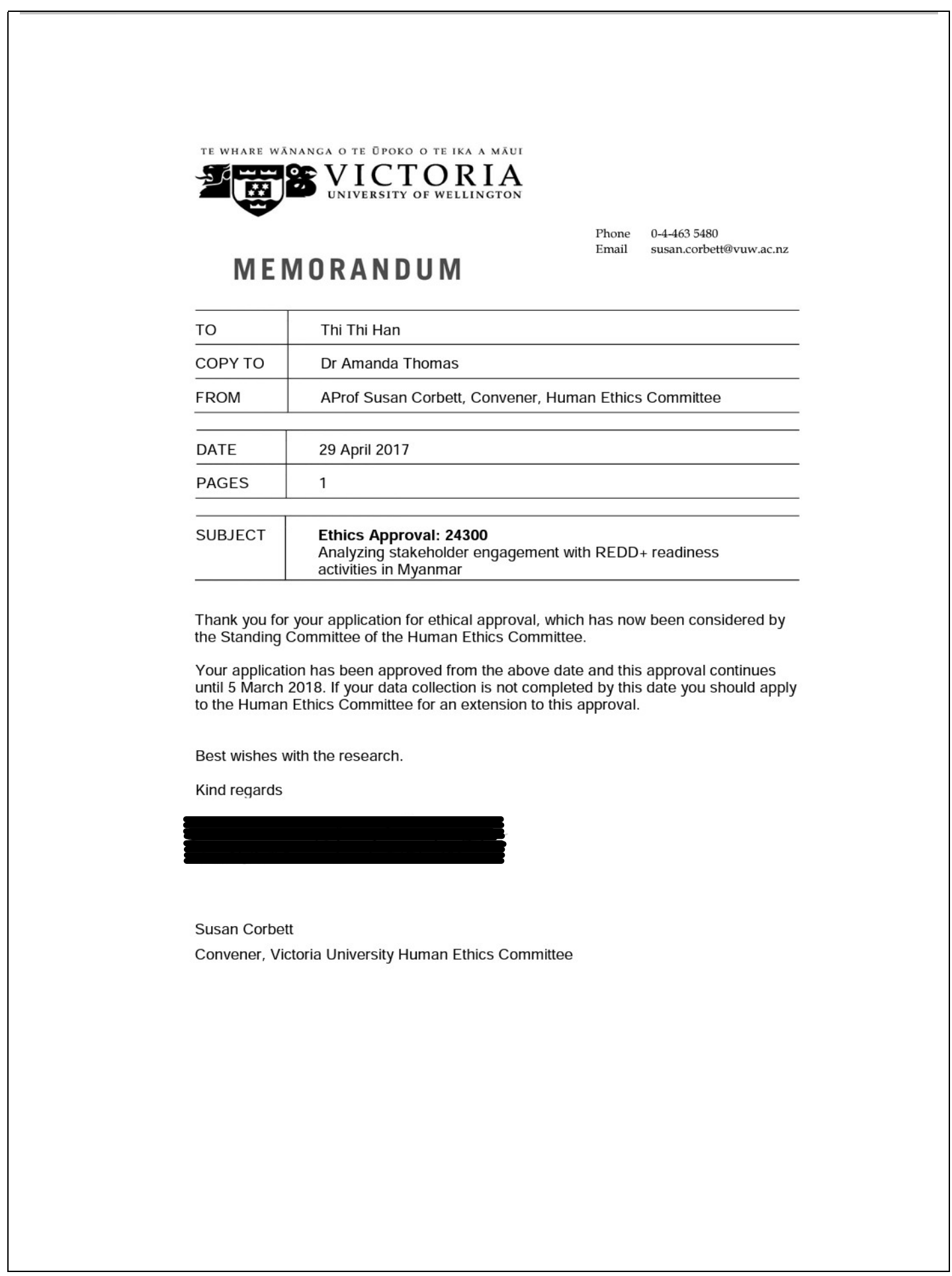


TE WHARE WĀNANGa O TE Õ POKO O TE IKA A MÃu 50
MEMORANDUM
Email susan.corbett@vuw.ac.nz

\begin{tabular}{l|l}
\hline TO & Thi Thi Han \\
\hline COPY TO & Dr Amanda Thomas \\
\hline FROM & AProf Susan Corbett, Convener, Human Ethics Committee \\
\hline DATE & 23 August 2017 \\
\hline PAGES & 1 \\
\hline \multicolumn{2}{|l}{} \\
\hline SUBJECT & $\begin{array}{l}\text { Ethics Approval: } 24300 \\
\text { Analyzing stakeholder engagement with REDD+ readiness } \\
\text { activities in Myanmar }\end{array}$ \\
\hline
\end{tabular}

Thank you for your request to amend your ethics approval. This has now been considered and the request granted.

Your application has approval until 5 March 2018. If your data collection is not completed by this date you should apply to the Human Ethics Committee for an extension to this approval.

Best wishes with the research.

Kind regards

Susan Corbett

Convener, Victoria University Human Ethics Committee 


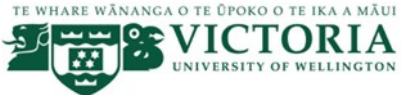

Analysing Stakeholder Engagement with REDD+ readiness activities in Myanmar

INFORMATION SHEET FOR INTERVIEW PARTICIPANTS

Researcher: Thi Thi Han, School of Geography, Environment and Earth Sciences, Victoria University of Wellington.

Thank you for your interest in this project. Please read this information before deciding whether or not to take part.

This research is being conducted to gain an understanding of stakeholder engagement with the Reducing Emission from Deforestation and Forest Degradation Plus (REDD+) in Myanmar. The REDD+ programme was initiated by the United Nations in order to manage forests sustainably, to tackle deforestation and forest degradation, and to protect threatened forests and wildlife in developing countries.

The research is to find out who is involved in REDD+ readiness activities in Myanmar and how they engage with REDD+; to investigate the interaction between different stakeholders in REDD+ initiative; to explore stakeholders' perspectives, aims and hopes for REDD+ initiative; and to analyze how Myanmar is approaching the REDD+ initiative.

To conduct this research, I wish to interview REDD+ stakeholders in Myanmar. Participants include representatives from: government officials, NGOs, international NGOs, donor agencies, related private sector, community, and academics.

\section{Interview Format}

The interview will take approximately 30-60 minutes. The interview will be audio recorded with your consent and will be written it up later. If you do not consent to being audio recorded, I will write notes based on the conversation. It is based on a semi-structured format so that the exact nature of the questions have not been determined in advance but will depend on the way that the interview develops. Should the line of questioning progress in a way that makes you uncomfortable you can decline to answer any question(s) at any stage.

\section{Participation}

Your participation is completely voluntary. If you agree to take part I will interview you at a 
place convenient to you e.g. workplace. I will ask you questions about REDD+ in Myanmar. You can stop the interview at any time, without giving a reason. You can withdraw from the study by contacting me at any point before 15 September 2017. If you withdraw, the information you provided will be destroyed or returned to you.

\section{Data Use and Storage}

This research is confidential. This means that myself and my supervisor, Dr. Amanda Thomas will be aware of your identity and your identity will not be disclosed in any reports, presentations, or public documentation. Pseudonyms will be used to protect your identity and to maintain anonymity. Participants will be referred to by role or organization or community rather than by name (please indicate on the consent form). However, you should be aware that in small projects your identity might be obvious to others in your community. All the data will be kept confidential and stored in a password-protected computer. Only my supervisor and I will read the notes or transcript of the interview. The interview transcripts, summaries and any recordings will be kept securely and destroyed 3 years after the research ends.

This research project is work towards my thesis to be submitted to the university to fulfill the requirements of the Master's degree. It is intended that the information from my research will be used in my Master Thesis, academic publication, conferences, and a summary report.

Feedback

You may receive a final summary of the findings if you wish (please indicate on the consent form). You may also receive a copy of the summary of your interview.

\section{If you accept this invitation, you have the right to:}

- choose not to answer any question;

- $\quad$ ask for the recorder to be turned off at any time during the interview;

- $\quad$ withdraw from the study before 15 September 2017;

- ask any questions about the study at any time;

- $\quad$ receive a copy of your interview recording;

- $\quad$ read over and comment on a written summary of your interview;

- $\quad$ agree on another name for me to use rather than your real name;

- be able to read any reports of this research by emailing the researcher to request a copy.

This research has been approved by the Victoria University of Wellington Human Ethics Committee (Ethics Approval: 24300). 
If you have any further questions, either now or in the future, please feel free to contact either Thi Thi Han (primary researcher) or Dr Amanda Thomas (supervisor) on the details below:

Student:

Name: Thi Thi Han

University email address:

hanthit@myvuw.ac.nz
Supervisor:

Name: Dr Amanda Thomas

Role: Lecture

School: School of Geography, Environment and Earth Sciences

Phone: +64-4-463-6117

amanda.thomas@vuw.ac.nz

\section{Human Ethics Committee information}

If you have any concerns about the ethical conduct of the research you may contact the Victoria University HEC Convener: Associate Professor Susan Corbett. Email susan.corbett@vuw.ac.nz or telephone +64-4-463 5480. 


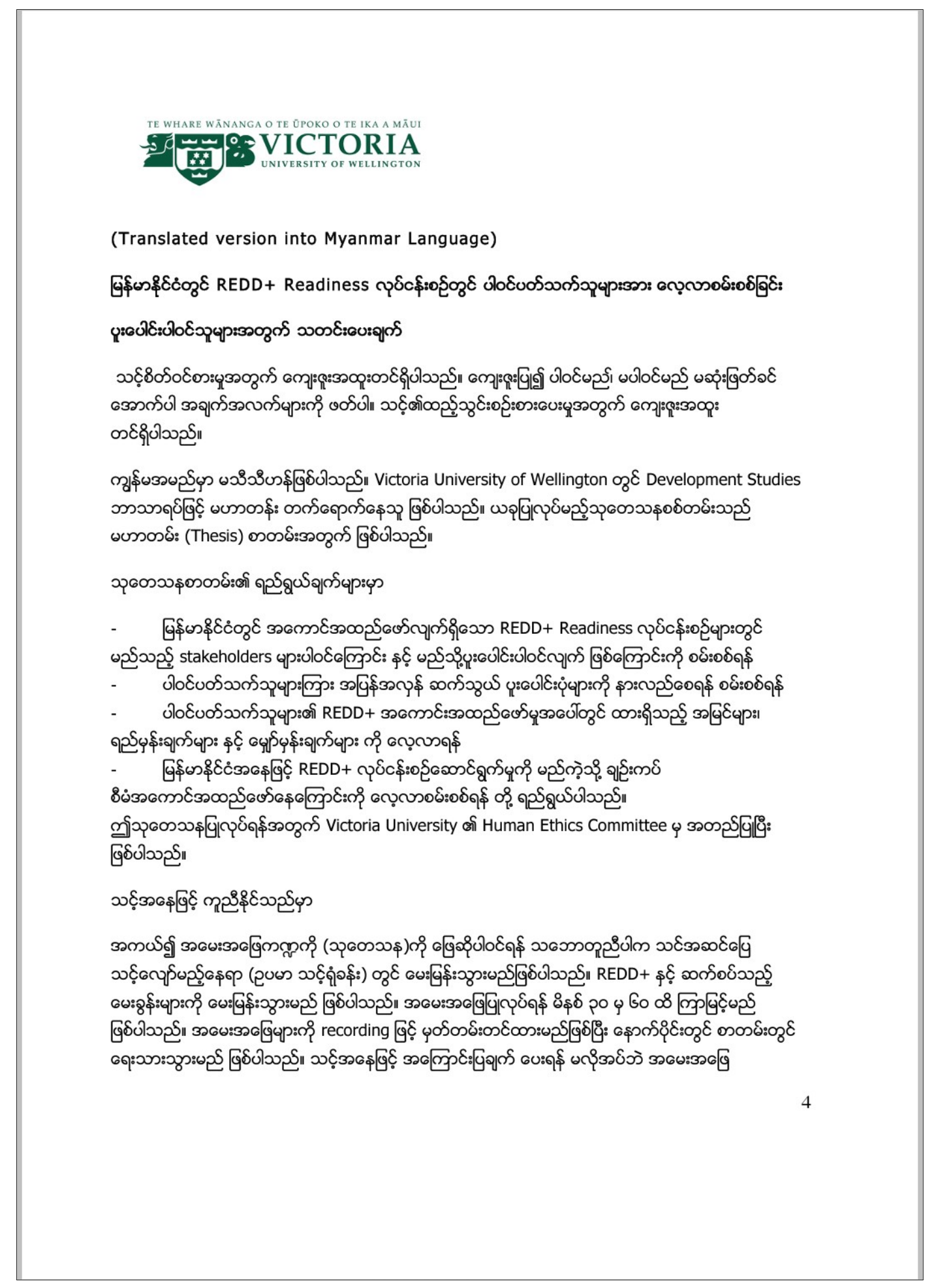




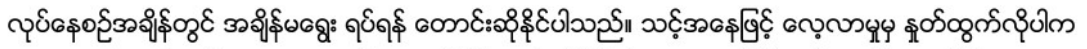

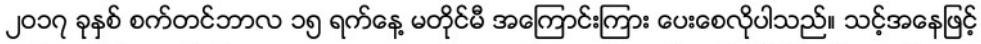

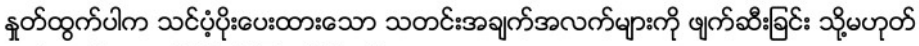

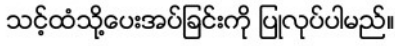

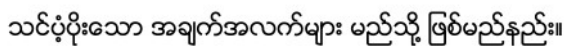

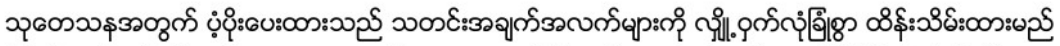

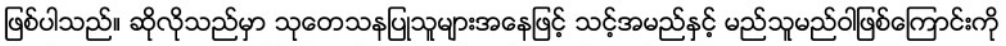

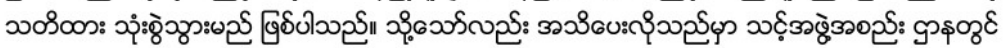

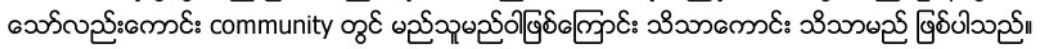

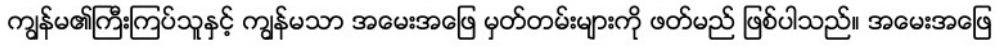

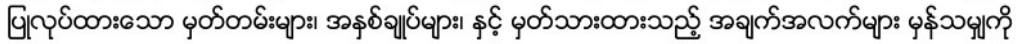

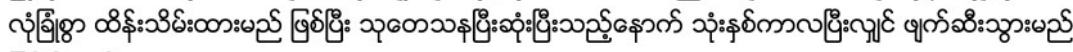

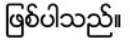

ग్య

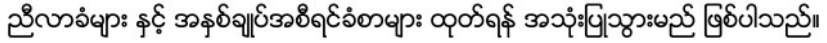

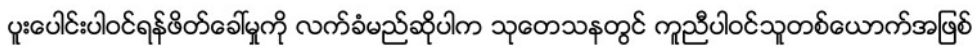

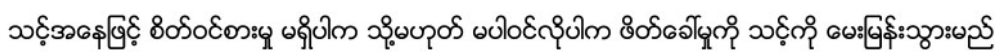

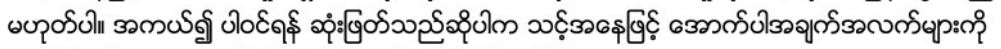

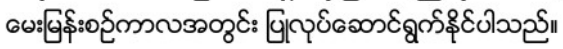

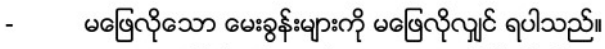

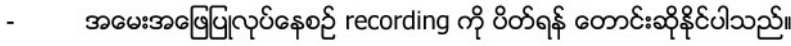

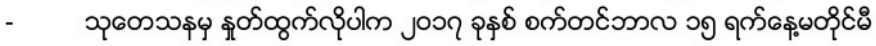

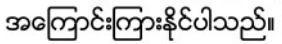

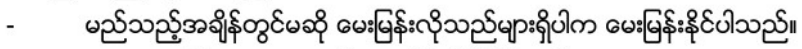

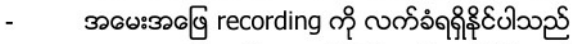

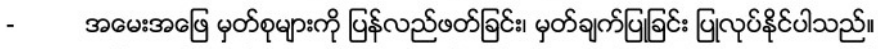

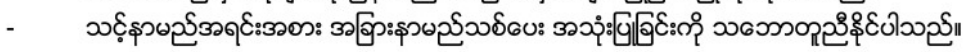

3ว

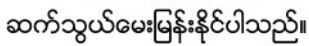




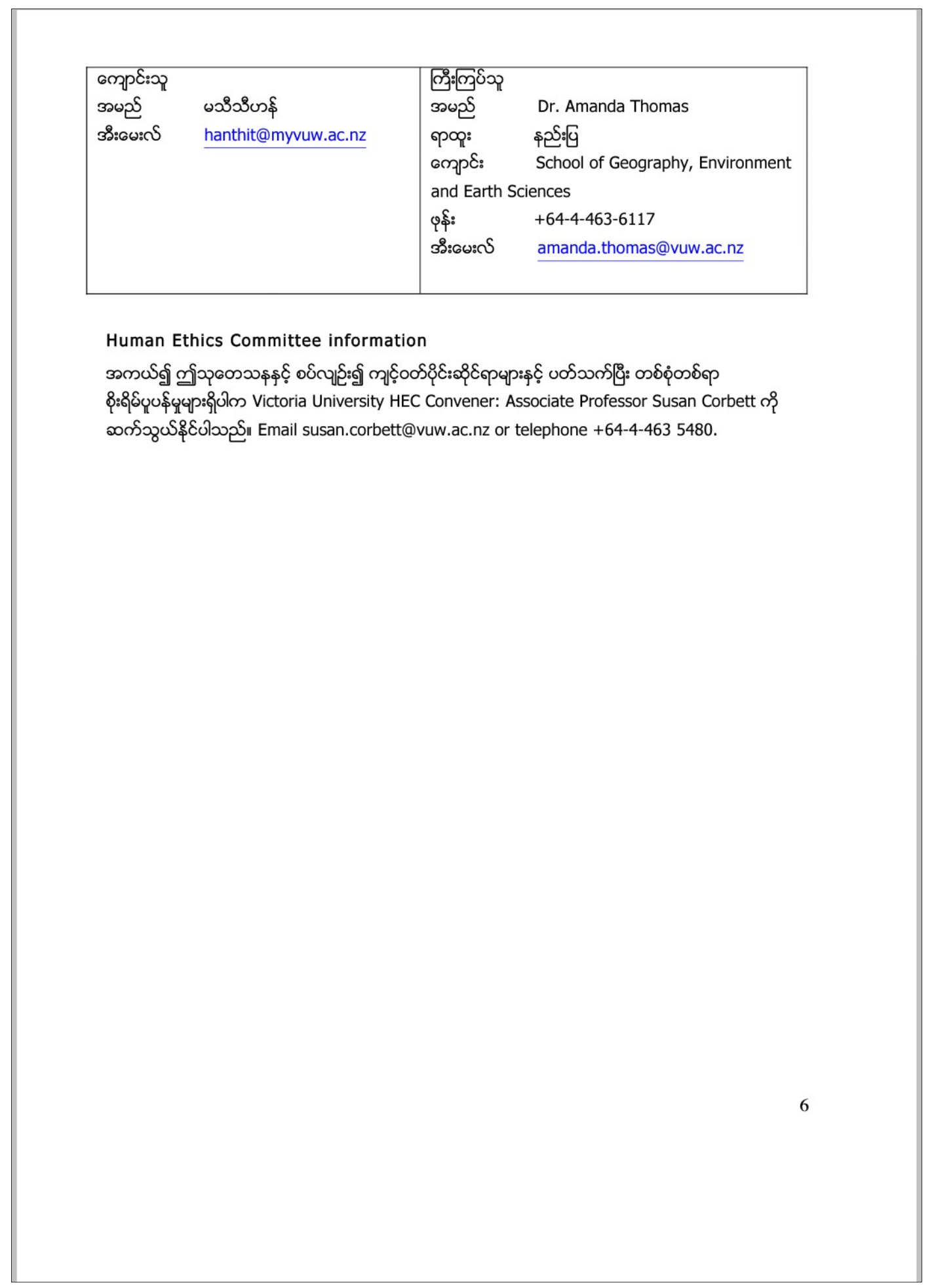




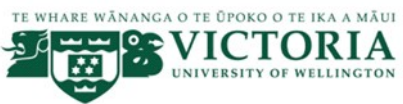

Analysing Stakeholder Engagement with REDD+ readiness activities in Myanmar

\section{CONSENT TO INTERVIEW}

This consent form will be held for 3 years.

Researcher: Thi Thi Han, School of Geography, Environment and Earth Sciences, Victoria University of Wellington.

I have read the Information Sheet and the project has been explained to me. My questions have been answered to my satisfaction. I understand that I can ask further questions at any time.

I understand that:

- I may withdraw from this study at any point before 15 September 2017, without giving any reason, and any information that I have provided will be returned to me or destroyed.

- The information I have provided will be destroyed 3 years after the research is finished.

- Any information I provide will be kept confidential to the researcher and the supervisor. I understand that the results will be used for a Master thesis and a summary of the results may be used in academic reports and/or presented at conferences. I consent to:

being audio recorded

(OR)

the interview will be taken notes

I consent to being referred to by role or by association with my organisation or community in any reports on this research:

Please indicate role:

(OR)

Please indicate organization:

(OR)

Please indicate community:

I would like to being referred to by a code name (pseudonym):

If yes, please identify a code name:
Yes O No O

Yes O No O

Yes $\mathrm{O}$ No O

Yes O No O 
I would like a copy of the summary of my interview:

I would like to receive a summary of the findings and have added my email address below.

If yes, contact details:

Signature of participant:

Name of participant:

Date:

Contact details:
Yes O No O

Yes O No O 
(Unofficial Translated version into Myanmar Language)

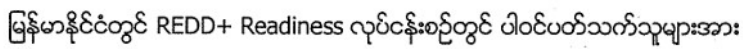

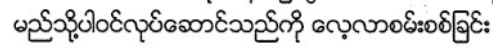

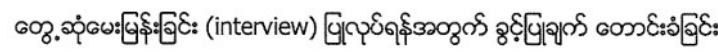

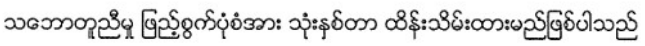

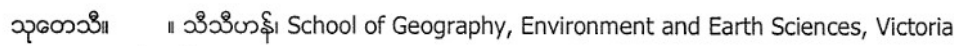
University of Wellington

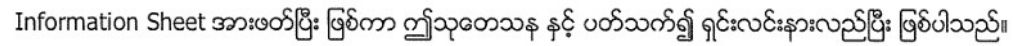
డv:৪ई:ตp:

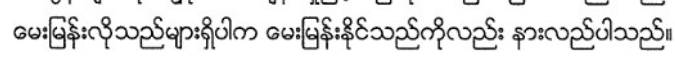

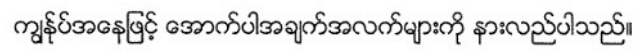

- ्యడ ๆরీ \$.

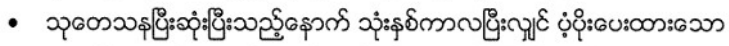

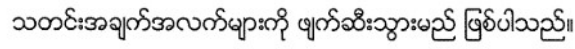

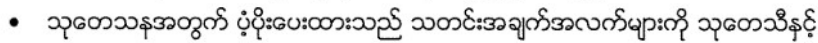

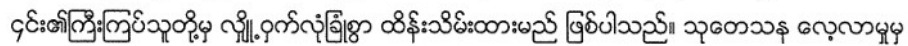

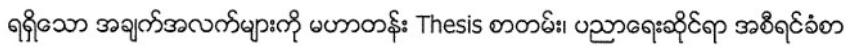

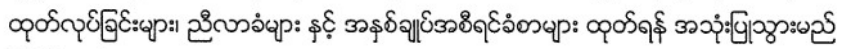

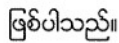

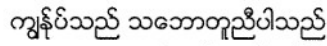

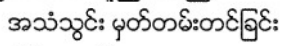

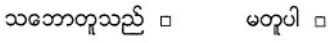

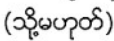

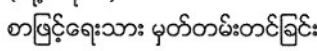

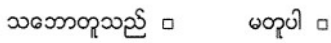




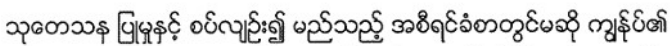

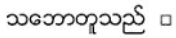

woñ -

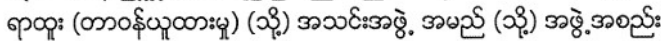

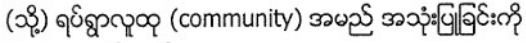



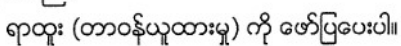

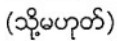

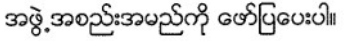

(బిబบ)

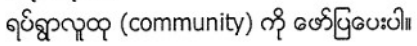

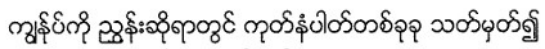

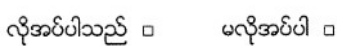

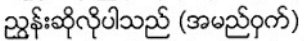

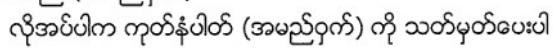

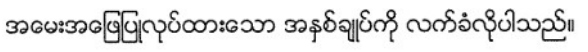

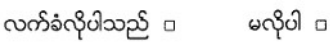

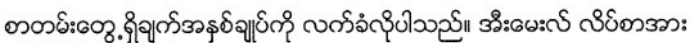

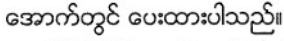

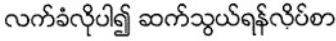

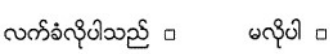

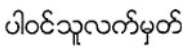

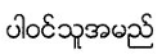

$6 \$ 8$

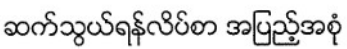


Appendix 4: Interview guide

Thi Thi Han

DEVE-Thesis (Interview Guide)

Student ID: 300336073

"Analyzing stakeholder engagement with the REDD+ readiness activities in Myanmar"

Interview Guide

The semi-structured interview will cover the following themes:

- Stakeholders' perspectives on REDD + implementation in Myanmar (Discourses around REDD +)

- Motivations and barriers to engage with REDD + implementation

- Potential benefits and opportunities through the REDD + implementation

- Challenges in implementing REDD+

- Stakeholders' participation and interaction between different stakeholders

The example questions are as follow:

\section{Demographic}

1. Tell me about yourself and background

2. What is your occupation in your institution/ organization?

3. What does your institution/ organization do?

\section{Main questions}

1. What is your role in REDD +? (Job titles and roles in any REDD + working group)

Motivation

2. How did you get involved in this programme? / What motivated your/ your institution's involvement?

Environmental issues, deforestation and REDD + project area- Background information (Brief)

3. In Myanmar, in your region, and your community, how would you describe the environmental issues concerning forests?

4. What are the main drivers of deforestation and forest degradation? (will vary in different areas) What impacts of deforestation and forest degradation are you experiencing?

5. How to address peace/ conflict and land issues in implementing REDD +? 
Perception

6. Do you think REDD + can help to prevent deforestation and forest degradation? If yes, in what way(s)?

7. Do you think REDD+ is needed in Myanmar? Why?

Motivation/ Opportunities/Interest

8. What do you expect to get out of the REDD+ programme?

9. What kind of challenges and opportunities are there for implementing REDD+ in Myanmar? Any soulution?

10. What are the barriers and motivators to participating in REDD+ for you and your organisation/community? For others? Any solution?

11. What do you think implementing REDD+ can bring to Myanmar/ to your community/ to your organization/ institution, etc.?

12. Do you think REDD+ can proivde solutions to local development/ livelihood?

Stakeholders participation and interaction (relationship)

13. Which stakeholders should be included in REDD+? Why? (If there is any new stakeholders involved in forest conservation and governance because of REDD+ initiative? If so, why and how?)

14. How did you/ your organization collaborate with other stakeholders? Is there any limitations or difficulties?

15. How is information shared among different stakeholders?

16. What role do the state/ regional government play in the readiness process of the REDD+ pilots?

17. How have trainings and workshops on REDD+ readiness and awareness been delivered?

18. How many and what kind of trainings/ workshops have your organization offered and to whom? How did you choose and invite your participants to training/ workshop? How you collobrate with other organizations and/ or institutions which provide capacity building to local community and government agencies?

19. Have you attended any awareness workshops or trainings on REDD+ readiness?

a. If 'yes', how many? Given by which organization?

b. If 'no', why not?

20. What are the barriers to attending or organizating training/ workshop? (Any suggestion for the improvement?) 
21. How do different donor agencies work together? Are there any collaborations? How do they interact (for example to give training or workshop?)

22. Are there new stakeholders involved in policy making for environmental conservation/ (and/or) forest governance and management?

a. If yes, who? And how? To what extent can they participate?

b. If no, who should be involved in the forest governance and management?

23. Do you think Myanmar will be ready for REDD+ implementation? Any recommendation?

24. Are there any final comments you have on land use and the potential for REDD+? 